\title{
New species of Geissorhiza (Iridaceae: Crocoideae) from the southern African winter rainfall zone, range extensions, taxonomic changes, and notes on pollen morphology and floral ecology
}

\author{
P. GOLDBLATT*, J.C. MANNING** and I. NÄNNI***
}

Keywords: Apoidea, compatibility, Empididae, floral biology. Geissorhiza Ker Gawl., nectar characteristics, Nemestrinidae, new keys, new species, pollen morphology, pollination, southern Africa, Tabanidae, taxonomy

ABSTRACT

\begin{abstract}
Field work during the past 15 years has resulted in the discovery of 12 new species of the westem southem African genus Geissorhiza Ker Gawl. and range extensions for several more. Following a survey of pollen morphology in the genus, we describe new pollen types in one section each of the two subgenera: five species of section Ciliatcie Goldblatt and two of section Weihea Eckl. ex Baker have more complex apertures than the plesiomorphic single aperture with a 2-banded operculum found in other species. In addition, populations currently referred to the typical white (cream)-flowered $G$. inflexa (D).Delaroche) Goldblatt with larger. pink, red or purple flowers, have a third pollen type and are recognized as $G$. erosa (Salisb.) R.C.Foster. The new species are $G$. altimontana from the high Langebery near Grootvadersbos: $G$. helmei from the Piketherg; $G$. lapidosa from the Du Toits Kloof Mtns; $G$. monticola from the Swartherg; $G$. platystigma from Darling, north of Cape Town; $G$. sufflava from the Piketherg; $G$. tricolor from Riversdale (all subgenus Weihea (Eckl. ex Baker) Goldblatt); and $G$. cantharophila from the Klein Roggeveld; $G$. demissa from the Kamiesberg. Githerg and Cold Bokkeveld; $G$. exilis from the Waaihock Mins in the Worcester District: $G$. reclinata from the Swartherg: and $G$. saxicola from the northern Cedarberg-Pakhuis Mountain complex (all subgenus Geissorhiza). We also report range extensions and provide morphological notes for several species, including $G$. monanthos Eckl.. new collections of which show that the inclusion of $G$. lewisiae R.C.Foster in that species was incorrect and we resurrect the species. The addition of 12 new species and recognition of $G$. erosa and $G$. lewisiae bring to 99 the number of species in the genus. New identification keys for Geissorhiza are provided that include all new species. We have also accumulated observations of floral ecology in the genus and integrate them with what is known about this aspect of the biology of Geissorhiza. Unusual strategies include deceptive pollination in $G$. 1 ulhaghensis F.Bolus by tabanid flies and in two species, pollination using empid flies in combination with halictid bees.
\end{abstract}

\section{INTRODUCTION}

Geissorhiza Ker Gawl., now with 99 species, is a large genus of Iridaceae subfamily Crocoideae Burnetl centred in the southern African winter rainfall zone (Goldblatt 1985; Goldblatt \& Manning 2000a; Manning et al. 2002) and largely confined to the Cape floristic region (as defined by Goldblatt \& Manning 2000a). Field work conducted in the decade since the publication of the last revision of the genus (Goldblatt 1985) resulted in the discovery and collection of four new species (Goldblatt 1989; Goldblatt \& Manning 1995a). increasing to 85 the number of known species. Further novelties that have accumulated since then include seven species of subgenus Weihea (Eckl. ex Baker) Goldblatt and five of subgenus Geissorthiza.

In addition, our knowledge of the pollen morphology of Geissorhiza has been expanded as a result of examination of pollen grains carried by insects captured after visiting Geissorhiza species (Goldblatt \& Manning 2000b, 2007). While monosulcate grains with a 2-banded operculum are typical of Crocoideae (Goldblatt et al. 1991) and also of Geissorhiza. the two species $G$. heterostyla L.Bolus and $G$. inflexa (D.Delaroche) Ker Gawl. (both subgenus Geissorhiza

* B.A. Krukoff Curator of African Botany. Missouri Botanical Garden. P.O. Box 299. St. Louis, Missouri 63166. USA.

** Compton Herbarium. South African National Biodiversity Institute. Private Bag X7. 7735 Claremont, Cape Town

*** Applied Biodiversity Research, South African National Biodiversity Institute. Private Bag X7.7735 Claremont. Cape Town

MS. received: 20(19-(1)3-31. section Ciliatae Goldblatt) were found to have pollen grains that depart from the norm in the genus and subfamily. Instead of the single, elliptic aperture, these species have a more complex condition with multiple apertures, described in detail below. Discovery of these striking pollen grains led us to examine a range of species of the genus. Most species of subgenus Weihea that we examined have normal grains with a 2-banded operculum as do species of subgenus Geissorhiza. However, four new species, $G$. camtharophila, $G$. exilis, $G$. saxicola and $G$. reclinata (all section Ciliatae), as well as $G$. bracteata and $G$. nana (section Weihea) have grains with complex, multiple apertures. Furthermore, the large-flowered populations of $G$. inflexa (sensu Goldblatt 1985), often with a pink, red or purple perianth, have a different pollen type from those with smaller, white flowers, indicating that they constitute a separate genetic race. For the most part these populations are readily separated from typical $G$. inflexa based on morphology as well as pollen type, and we recognize these plants as a separate species, $G$. erosa. We also include range extensions and morphological notes for $G$. arenicola, $G$. divaricata, $G$. heterostyla and $G$. tenella. With the 12 new species described here and the resurrection of $G$. erosa, Geissorhiza now comprises 99 species, all occurring within the Greater Cape Floristic Region (sensu Born et al. 2006) with only $G$. bracteala extending outside its confines. We provide new keys to the two subgenera of Geissorhiza (Appendix 1). which accommodate all species described since the publication of the last revision of the genus (Goldblatt 1985). The classification of the genus and renumbering of the species is presented in Table 1. 
TABLE 1.-Classification of Geissorhiza species arranged by subgenus and section including new species described here, based on Goldblatt's (1985) infrageneric classification

\begin{tabular}{|c|c|}
\hline \multicolumn{2}{|c|}{ Subgenus Weihea (Eckl. ex Baker) Goldblatt } \\
\hline Section Weihea Eckl. ex Baker & Section Includanthera Goldblatt \\
\hline 1. G. inconspicua Baker & 29. G. esterhuvseniae Goldblatt \\
\hline 2. G. elsiae Goldblatt & 30. G. cedarmontana Goldblatt \\
\hline \multicolumn{2}{|l|}{ 3. G. roseoalba (G.J.Lewis) Goldblatt } \\
\hline 4. G. outeniquensis Goldblatt & Section Angustifolia Goldblatt \\
\hline 5. G. fourcadei (L.Bolus) G.J.Lew is & 31. G. lithicola Goldblatt \\
\hline 6. G. uliginosa Goldblatt \& J.C.Manning & 32. G. purpurascens Goldblatt \\
\hline 7. G. foliosa Klatt & 33. G. humilis (Thunb.) Ker Gawl. \\
\hline 8. G. tricolor Goldblatt \& J.C.Manning, sp. nov. & 34. $G$. darlingensis Goldblatt \\
\hline 9. G. nigromontana Goldblatt & 35. G. hispidula (R.C.Foster) Goldblatt \\
\hline 10. G. altimontana Goldblatt \& J.C.Manning, sp. nov. & 36. G. pappei Baker \\
\hline 11. G. delicatula Goldblatt & 37. G. intermedia Goldblatt \\
\hline 12. G. monticola Goldblatt \& J.C.Manning, sp. nov. & 38. G. unifolia Goldblatt \\
\hline 13. G. bracteata Klatt & 39. G. juncea (Link) A.Dietr. \\
\hline 14. G. nana Klatt & 40. G. furva Ker Gawl. ex Baker \\
\hline 15. G. setacea (Thunb.) Ker Gawl. & 41. G. sufflava Goldblatt \& J.C.Manning \\
\hline 16. G. lapidosa Goldblatt \& J.C. Manning, sp. nov. & 42. G. stenosiphon Goldblatt \\
\hline \multicolumn{2}{|l|}{ 17. G. ornithogaloides Klatt } \\
\hline 18. G. malmesburiensis R.C.Foster & Section Ixiopsis Goldblatt \\
\hline 19. G. platystigma Goldblatt \& J.C.Manning, sp. nov. & 43. G. umbrosa G.J.Lewis \\
\hline 20. G. geminata E.Mey. ex Baker & 44. G. alticola Goldblatt \\
\hline 21. G. ovalifolia R.C.Foster & 45. $G$. hesperanthoides Schltr. \\
\hline 22. G. bolusii Baker & 46. G. cataractarum Goldblatt \\
\hline 23. G. parva Baker & 47. G. mubigena Goldblatt \\
\hline 24. G. ovata (L.f.) Asch. \& Graebn. & Section Engusiphon (G.J.Lew is) Goldblatt \\
\hline & 48. G. helmei Goldblatt \& J.C.Manning, sp. nov. \\
\hline Section Tortuosa Goldblatt & 49. G. brevinuba (G.J.Lew is) Goldblatt \\
\hline 25. G. corrugata Klatt & 50. G. schinzii (Baker) Goldblatt \\
\hline 26. G. spiralis (Burch.) M.P.de Vos ex Goldblatt & 51. G. longifolia (G.J.Lewis) Goldblatt \\
\hline 27. G. karooica Goldblatt & 52. G. confusa Goldblatt \\
\hline & 53. $G$. bonaspei Goldblatt \\
\hline Section Pusilla Goldblatt & 54. G. tenella Goldblatt \\
\hline 28. G. pusilla (Andrews) Klatt & 55. G. exscapa (Thunb.) Goldblatt \\
\hline
\end{tabular}

\begin{tabular}{|c|c|}
\hline \multicolumn{2}{|c|}{ Subgenus Geissorhiza } \\
\hline Section Intermedia Goldblatt & 78. G. silenoides Goldblatt \& J.C.Manning \\
\hline \multicolumn{2}{|l|}{ 56. G. similis Goldblatt } \\
\hline 57. G. scillaris A.Dietr. & $\begin{array}{l}\text { Section Planifolia Goldblatt } \\
\text { 79. G. aspera Goldblatt }\end{array}$ \\
\hline Section Geissorhiza & 80. G. demissa Goldblatt \& J.C.Manning, sp. nov. \\
\hline 58. G. imbricata (D.Delaroche) Ker Gawl. & 81. G. inaequalis L.Bolus \\
\hline 59. G. purpureolutea Baker & 82. G. lewisiae R.C.Foster \\
\hline 60. G. barkerae Goldblatt & 83. G. monanthos Eckl. \\
\hline 61. G. louisabolusiae R.C.Foster & 84. G. Iulhaghensis F.Bolus \\
\hline \multicolumn{2}{|l|}{ 62. G. brehmii Eckl. ex Klatt } \\
\hline 63. G. sulphurascens Schltr. ex R.C.Foster & Section Ciliatae Goldblatt \\
\hline 64. G. minuta Goldblatt & 85. G. namaquensis W.F.Barker \\
\hline 65. G. eurystigma L.Bolus & 86. G. kamiesmontana Goldblatt \\
\hline 66. G. mathensii L.Bolus & 87. G. divaricata Goldblatt \\
\hline \multirow[t]{2}{*}{ 67. G. radians (Thunb.) Goldblatt } & 88. G. subrigida L.Bolus \\
\hline & 89. $G$. heterost la L.Bolus \\
\hline Section Monticola Goldblatt & 90. G. comtharophila Goldblatt \& J.C.Manning, sp. nov. \\
\hline 68. G. burchellii R.C.Foster & 91. G. reclinata Goldblatt \& J.C.Manning, sp. nov. \\
\hline 69. G. grandiffora Goldblatt & 92. G. arenicola Goldblatt \\
\hline 70. G. callista Goldblatt & 93. G splendidissima Diels \\
\hline 71. G. tabularis Goldblatt & 94. $G$ inflexa (D.Delaroche) $\operatorname{Ker}$ (jawl. \\
\hline 72. G. ramosa Ker Gawl. ex Klatt & 95. G. erosa (Salisb.) R.C.Foster \\
\hline 73. G. brvicola Goldblatt & 96. $G$. exilis Goldblatt \& J.C.Manning. sp. nov. \\
\hline 74. G. scopulosa Goldblatt & 97. G. saricola Goldblatt \& J.C. Manning. sp. nov. \\
\hline 75. G. ciliatula Goldhlatt & 98. G. erubescens Goldblatt \\
\hline 76. G. pseudinaequalis Goldblatt & 99. G. leipoldtii R.C.Foster \\
\hline 77. G. rupicola Goldblatt \& J.C.Manning & \\
\hline
\end{tabular}

Lastly, we review what little is known about the floral ecology of Geissorhiza and present a range of observations on pollinator visits and nectar characteristics of several species. Available information shows that pollination in the genus is dominated by female bees of the families Andrenidae, Colletidae, Halictidae and Melittidae plus workers of Apis mellifera (Apidae), often in combination with hopliine scarab beetles, short-proboscid Tabanidae and buttertlies. The specialized pollination system using one or more species of long-proboscid Nemestrinidae and Tabanidae is the second most important system in Geissorhiza, confirmed for five species and inferred for three more. Pollination primarily by hopliine scarab beetles is rare, and is reported for the first time in the genus, as are visits by empidid tlies (Empididae), and also deceptive pollination by short-proboscid Tabanidae. 


\section{MATERIALS AND METHODS}

Pollen grains obtained from fresh flowers or from herbarium specimens of a range of species (Table 2) were extracted from anthers with a needle moistened in Calberla's fluid (Ogden et al. 1974) and mounted on glass slides in a drop of the same fluid. Preparations were examined after 2-24 hours, by which time the exine is stained a darker colour than the aperture and grain contents. Only two species of the genus were included in a previous survey of pollen types in Crocoideae (Goldblatt et al. 1991). Thus, in an effort to determine the extent of the variation in pollen morphology in the genus, we have surveyed a wide range of species belonging to both subgenera and all sections (Table 1 ).

Nectar volumes were measured using micro tubes, and nectar concentrations were determined with a Bellingham \& Stanley refractometer $(0-50 \%$ ) (Goldblatt et al. 2004a; Manning \& Goldblatt 2005).

For pollinator observations, insects visiting flowers and seen to contact anthers or stigmatic surfaces were captured and killed using ethyl acetate fumes following methods described by Goldblatt et al. (2004a) and Goldblatt \& Manning (2007). The identity of pollen carried by captured insects was determined by microscopic examination of samples removed from their bodies using dissecting needles in the same way as described above for sampling from herbarium specimens.

\section{RESULTS}

\section{POLLEN MORPHOLGY}

Our survey of pollen morphology establishes the presence of the plesiomorphic type pollen grains reported in our earlier survey of Crocoideae (Goldblatt et al. 1991) as the most common type in the genus (Table 2). These grains are monosulcate with tectate-perforate exine bearing small supratectal spinules. The sulcus field is largely smooth apart from a pair of narrow exine bands (elongated opercula), lying parallel to one another along the long axis of the aperture (Figure l A). Often there is also a sprinkling of exine material lying in the centre of the three apertural zones defined by the opercular bands. One species of subgenus Weihea, $G$. parva, has poorly developed operculum bands, represented merely by two sparsely beaded lines of exine.

Two species of subgenus Weihea, among those examined, and four of subgenus Geissorhiza have grains of remarkably different appearance (Table 2). In contrast to the majority of species in the genus, Geissorhiza cantharophila, $G$. exilis, $G$. inflexa, $G$. reclinata, $G$. saxicola and most populations of $G$. heterostyla (subgenus Geissorhiza section Ciliatae) and $G$. bracteata and $G$. nana (subgenus Weihea section Weihea) have grains that depart radically from the standard type. Grains have typical tectate-perforate exine, but have more complex apertures. The \pm orbicular and slightly larger grains of $G$. bracteata, G. cambarophila, $G$. nana and some populations of $G$. heterostyla have two discrete apertures, a smaller elliptic one surrounded by a broad band of exine (? or operculum) lying within a larger \pm elliptic or cir- cumferential sulcus (Figure 1B). We interpret this grain as derived from the basic type in which the two bands of the operculum have become wider and longer and their ends have fused, leaving an island of enclosed apertural membrane within the operculum. The aperture surrounding this structure may also be elliptic or continuous around the grain, leaving the non-apertural part of the grain as two separate pieces of exine. Curiously, six populations of $G$. heterostyla examined (Table 2), all from the north of its range, have normal grains with a 2-banded operculum. We have re-examined these collections and find no taxonomically significant difference between them and the more common $G$. heterostyla. One of the collections with normal type pollen grains (Goldblatt $6216 \mathrm{MO}$ ) even consists of the mixture of shortand long-styled plants that is currently understood to be unique to this species.

Some populations of Geissorhiza inflexa have $G$. heterostyla-type grains (Figure IB: Table 2) but in others the grains have five or six bands of exine running across the grain separated by apertures of about the same width (Figure IC). The bands merge at one pole so that in this view five or six elliptic zones of apertural membrane are visible, whereas viewed at right angles, the apertures run the length of the grain separated by long bands of exine. At the opposite end the exine bands do not quite fuse but adjacent bands fuse toward their tips. All the large-flowered populations of $G$. inflexa, with either red, pink, purple or white flowers have this apertural pattern. These large-flowered colour morphs were included in $G$. inflexa by Goldblatt (1985) without infraspecific recognition.

A last variant is the plant described here as Geissorhiza reclinata, which has pollen grains with two large horse-
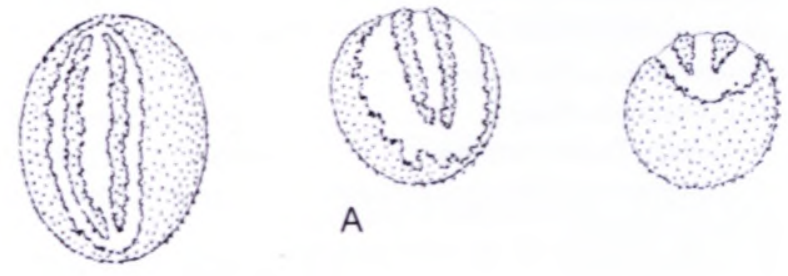

A
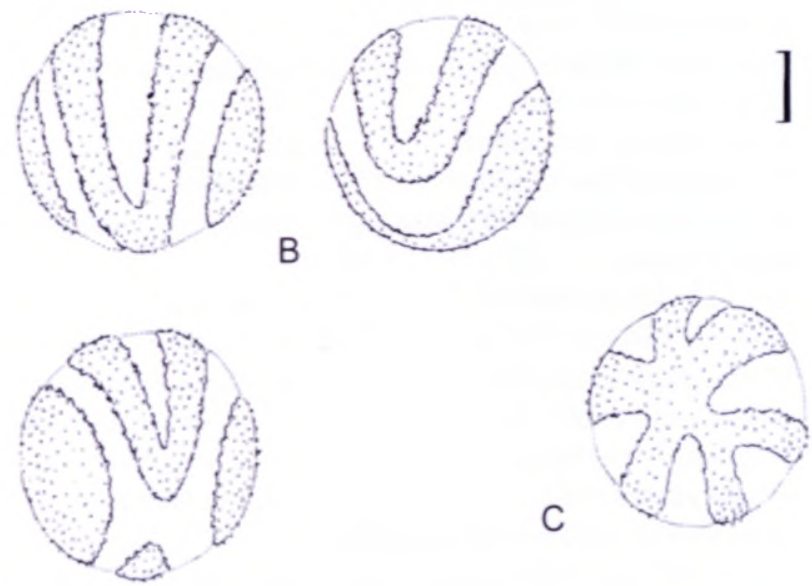

FIGURE 1.-Pollen grains of Geissorhiza species. A. G. arenicola. Goldhlatt \& Vanning 9465 (NB(i): B. G. heterosnla. Goldhlan \& Porter 12185 (NBG): C. G erosa. Helme 2247 (NBG). Scale bar: $2(0) \mu \mathrm{m}$ 
TABLE 2.-Pollen types in Geissorhiza species arranged by subgenus according to Goldblatt's (1985) infrageneric classification. Herbaria are abbreviated following Holmgren et al. (1990)

Taxon

Collection data and herbarium acronym or literature reference

Grains monosulcate with two-banded operculum

Subgenus Weihea

Section Weihea
G. foliosa Klatt
G. inconspicua Baker
G. monticola Goldblatt \& J.C.Manning
$G$. ornithogaloides Klatt
G. ovata (L.f.) Asch. \& Graebn.
G. parva Baker

Section Angustifolia
G. juncea (Link) A.Dietr.
$G$. aff. pappei Baker
$G$. purpurascens Goldblatt
G. sufflava Goldblatt \& J.C.Manning

Section Ixiopsis

G. nubigena Goldblatt

Section Engusiphon
G. bonaspei Goldblatt
$G$. confusa Goldblatt
G. exscapa (Thunb.) Goldblatt
G. longifolia (G.J.Lew is) Goldblatt
G. schinzii (Baker) Goldblatt
G. tenella Goldblatt

Goldblatt \& Manning 10783 (MO)

Goldblatt \& Nänni 11580 (MO)

Goldblatt \& Porter $1 / 872$ (MO, NBG)

Goldblatt \& Nänni 1/197 (MO), Goldblatt 1/467 (MO)

no voucher

Goldblatt \& Porter 12266 (MO) (operculum vestigial)

Goldblatt 11554 (MO)

Goldblatt \& Manning 9944 (MO. NBG)

Goldblatt \& Manning /1560 (MO, NBG)

Goldblatt \& Manning 9468 (MO, NBG)

Goldhlatt $10608(\mathrm{MO})$

Goldblatt 11640)(MO)

Goldblatt \& Manning 10119 (MO)

Goldblatt \& Manning $10346(\mathrm{MO})$

Goldblall \& Manning 11486(MO); Oliver 4070 (NBG)

Goldblatt et al. (1991)

Goldblatt \& Manning $10376(\mathrm{MO})$

\section{Subgenus Geissorhiza}

Section Cilialae

\section{G. divaricata Goldblatt \\ $G$. erubescens Goldblatt \\ $G$. hetenostrla L.Bolus}

\section{G. leipoldtii R.C.Foster}

G. namaquensis W.F.Barker

G. subrigida L.Bolus

Section Geissorhiza
G. barkerae Goldblatt
G. eurystigma L.Bolus
G. louisabolusiae R.C.Foster
$G$. purpureolusea Baker
G. radians (Thunb.) Goldblatt
G. sulphurascens Schltr. ex R.C.Foster

Section Intermedia

G. scillaris A.Dietr.

Section Monticola
$G$. bricola Goldblatt
G. burchellii R.C.Foster
G. callista Goldblatt
G. grandiflora Goldblatt
$G$. pseudincequalis Goldblatt
$G$ ramosa Ker Gawl. ex Klatt
Section Planifolia
$G$. arenicola Goldblatt
$G$. aspera Goldblatt
$G$. inaequalis L.Bolus
G. monanthos Eckl.
G. splendidissima Diels
G. tulbaghensis F.Bolus

G. silenoides Goldblatt \& J.C.Manning
Goldblatt 10291 (NBG

Compron 19964 (NBG)

Goldblatt 6261, 5305, 5824 (MO); Goldhlatt \& Manning 10293 (MO); Goldhlatt \& Porter 12770 (MO), 12822 (MO, NBG)

Van Rooven et al. $718(\mathrm{NBG})$

Goldblatt \& Manning 9705 (NBG)

Lewis $5886(\mathrm{NBG})$

Goldblatt 6391 (NBG)

no voucher

Goldhlatt \& Porter $12605(\mathrm{MO})$

Goldblatt \& Manning 11139 (NBCi)

Goldblatt et al. (1991); Van Zyl 3512 (NBG)

Snijman 896 (NBG); Goldhlall \& Manning 9465 (NBG)

Goldblatt et al. (1991)

Williamson 3683 (NBG

Williams 3754 (NBG)

Goldblatt 8680 (NBG)

Oliver \& Oliver $11468(\mathrm{NBG})$

Manning 2220 (NBG)

Esterhuysen 36144 (NBG). 33703 (MO)

Goldblatt \& Manning 9739 (NBG)

Goldblatt \& Nänni //I54 (NBG); Goldhlatt \& Porter II888A (NBG)

Goldhlatt \& Manning 9403 (NBG)

Goldblatt \& Porter $1 / 795$ (NBG)

Bevers 77 (NBG): Goldhlatt \& Nänni $/ 1553$

Barker 9549 (NBG)

Solomon 38 (NBG)

\section{Grains with complex multiple apertures}

Type I grains: two elliptic apertures, smaller nested in larger; type 2: more complex apertures described in text

Subgenus Weihea: section Weihea

G. bracteata Klatt

G. nana Klatt type 1: Goldhlatt \& Porter 12358A (MO); Goldblatt \& Porter 127/4 (MO, NBG)

type 1: Goldhlatt \& Manning 12255 (MO) 
TABLE 2.-Pollen types in Geissorhiza species arranged by subgenus according to Goldblatt's (1985) infrageneric classification. Herbaria are abbreviated following Holmgren et al. (1990) (cont).

\begin{tabular}{|c|c|}
\hline \multicolumn{2}{|l|}{ Subgenus Geissorhiza: section Ciliatae } \\
\hline G. saxicola Goldblatt \& J.C.Manning & type 1: Goldblan \& Manning 9094 (MO) \\
\hline G. cantharophila Goldblatt \& J.C.Manning & type 1: Hanekom 1562 (MO); Manning 2797 (NBG); Goldblatt \& Porter 12704 (MO, NBG) \\
\hline G. heterostyla L.Bolus & $\begin{array}{l}\text { type 1: Goldblatt 6203 (MO); Goldblatt \& Porter 12185. 12328, 12791, 12937,12942 (MO); Gold- } \\
\text { blatt \& Manning 12174(MO); Oliver } 9643 \text { (NBG); Snijman } 734 \text { (NBG) }\end{array}$ \\
\hline G. inflexa (D.Delaroche) Ker Gawl. & $\begin{array}{l}\text { type 1: Boucher } 5439(\mathrm{NBG}) ; \text { Goldblatt 2497,3996,6203 (MO) (small white-flowered plants) } \\
\text { type 2: Goldhlatt 2497, 11422.4; /1426, 12995(MO); Goldblatt \& Manning I2687 (MO); Helme } \\
2247 \text { (NBG) }\end{array}$ \\
\hline G. exilis Goldblatt \& J.C.Manning & type 1: Goldhlatt \& Manning 13041 (MO, NBG) \\
\hline G. reclinata Goldblall \& J.C.Manning & type 2: Goldblatt \& Porter 12057 (MO, NBG) \\
\hline
\end{tabular}

shoe-shaped bands of exine oriented at right angles to one another and thus one large sulcus of irregular shape.

Pollen grains with a 2-banded operculum are not universal in Crocoideae but are the only type known in 16 of the 29 genera recognized in the subfamily (Goldblatt et al. 1991). Exceptions are: 1, Ixia and Xenoscapa, one species of Freesia, section Fastigiata of Lapeirousia, a few species of Romulea, and several of Thereianthus, which have a 1-banded operculum (Goldblatt \& Manning 1995b); 2, Syringodea and some species of Crocus, which have inaperturate grains (e.g. De Vos 1974); 3, Cyanixia and Zygotritonia, which have trisulculate grains (Goldblatt et al. 2004b); 4, Savannosiphon, which has polyaperturate pollen grains (Goldblatt et al. 1991); 5, Afrocrocus, which has trizonosulculate grains; and 6 , Micranthus, which has zonosulcate grains with the exine reticulate except close to the aperture where the sculpturing grades from microreticulate to perforate immediately adjacent to the aperture margin (Goldblatt et al. 1991. and unpublished data).

The discovery of unusual pollen grains in two species of section Weihea of subgenus Weihea and several of section Ciliatae of subgenus Geissorhiza represents another significant departure from the standard type in Crocoideae and a striking specialization within the genus. The presence of divergent pollen types in Geissorhiza is most parsimoniously viewed as evidence for a close relationship of the species of each subgenus that share the character even though the precise morphology of the apertures may differ. G. heterostyla and $G$. inflexa are already believed to be closely related on account of their similar, derived leaf blades (Goldblatt 1985), and $G$. exilis shares a similar vegetative morphology (Goldblatt 1985). A fourth species with this pollen type, $G$. cantharophila, until now included in $G$. heterostyla, is obviously immediately related to that species. The appearance of normal-type pollen grains in the six northernmost populations sampled of $G$. heterostyla (Langberg to Hantamsberg and Bokkeveld Mountains) is surprising. No feature sets them apart in the genus and all that can be concluded at present is that the variation has a geographic component. Variation in pollen grain morphology within a species is surprising since pollen and seed morphology are widely believed to be highly conservative. Variation even within a genus on such a scale as reported here is unexpected. In section Weihea, $G$. bracteata and $G$. nana share similar divergent pollen grains, which supports Goldblatt's (1985) inference based on morphology that they are immediately allied.
The broader significance of the divergent pollen grains is uncertain. None of the species seem particularly unusual morphologically in Geissorhiza. Two of them, $G$. inflexa and $G$. heterostyla have what may be termed a generalist pollination system that includes female bees and Apis mellifera workers, hopliine beetles, and occasionally butterflies, a pattern encountered widely in Geissorhiza (see below). Geissorhiza cantharophila is adapted for pollination by hopliines, three species of which have been captured on the flowers.

Another issue concerns the significance at the taxonomic level of the grains of the large-flowered 'Geissorhiza erosa' populations of $G$. inflexa, which have 5 (or 6) apertures. The justification for the reduction of this taxon in $G$. inflexa by Goldblatt (1985) was the presence in $G$. inflexa sensu lato of populations with larger than usual. pink or purple flowers that seemed to link the typical and common form of $G$. inflexa, which has moderate-sized, white flowers, with the large-flowered $G$. erosa with its brilliant scarlet perianth. In the light of the consistent association of this different pollen with large, white, pink or red-flowered plants we conclude that the larger-flowered plants constitute a separate genetic race and we re-evaluate their taxonomic status below.

\section{SYSTEMATICS}

The new species are arranged numerically within subgenera. Their position and number in the classification of Geissorhiza is given in Table 1.

\section{Subgenus Weihea (Eckl. ex Baker) Goldblant}

8. Geissorhiza tricolor Goldblatt \& J.C.Manning, sp. nov.

Plantae 100-150(-200) $\mathrm{mm}$ altae, cormo globoso $5-6 \mathrm{~mm}$ diam. tunicis concentricis lignosis duris, foliis 6 ad 8 erectis vel falcatis $15-50 \times(2-) 3-5 \mathrm{~mm}$ planis. caule erecto simplici vel 1 - vel 2-ramoso, spica (1)2-vel 3 -flora, bracteis viridibus distaliter rubro-suffusis (12-) $15-18 \mathrm{~mm}$ longis, floribus actinomorphis rotatis aureis ad centrum atromarroninis nitidis ad tubum flavoviridibus inodoris $30-38 \mathrm{~mm}$ diam., tubo perianthii $3-4 \mathrm{~mm}$ longo, tepalis late obovato-quadratis $15-18 \mathrm{~mm}$ longis, filamentis atromarroninis $\pm 3 \mathrm{~mm}$ longis, antheris sub anthesi $\pm 5 \mathrm{~mm}$ longis, stylo excentrico $\pm 6 \mathrm{~mm}$ longo ramis $2.5-3.0 \mathrm{~mm}$ longis.

TYPE.-Western Cape, 3421 (Riversdale): Werner Frehse Nature Reserve, south of N2, east of Riversdale. 
pebbly ferricrete in renosterveld-fynbos transitional vegetation, (-AB), 6 October 2006, Manning 3071 (NBG, holo.; MO, PRE, iso.).

Plants $100-150(-200) \mathrm{mm}$ high, with pale membranous cataphylls. Corm obliquely globose, asymmetric and flattened slightly below on one side, 5-6 mm diam., tunics concentric, brown, hard and woody, fragmenting irregularly into sections. Stem erect, simple or 1 - or 2-branched, either from base or from upper stem nodes. Leaves $6-8$, lower 4 or 5 basal and largest, lanceolate to sword-shaped, short and mostly less than one third as long as stem, 15-50 $\times(2-) 3-5 \mathrm{~mm}$, upper decreasing progressively in size, uppermost bract-like and often without blade. Spike (1)2- or 3-flowered; bracts green, flushed reddish distally, elliptic, (12-)15-18 mm long, subequal, inner not notched apically. Flowers rotate, golden yellow with glossy blackish maroon eye covering basal quarter of tepals, yellowish green in tube, outer tepals flushed reddish on reverse, unscented, $30-38 \mathrm{~mm}$ diam.; perianth tube funnel-shaped, 3-4 mm long; tepals broadly obovate-quadrate, margins irregularly crenulate in distal half, 15-18 mm long, outer $10-11 \mathrm{~mm}$ wide, inner $12-14 \mathrm{~mm}$ wide. Stamens: filaments $\pm 3 \mathrm{~mm}$ long, exserted for \pm 1 $\mathrm{mm}$, dark maroon; anthers $\pm 5 \mathrm{~mm}$ long at anthesis, pollen yellow. Ovary obovoid, $5 \mathrm{~mm}$ long; style eccentric, $\pm 6 \mathrm{~mm}$ long, dark maroon, exserted for $\pm 1 \mathrm{~mm}$, dividing opposite lower half of anthers, style branches 2.5-3.0 $\mathrm{mm}$ long. Capsules and seeds unknown. Flowering time: September and early October; flowers opening between mid-morning and early afternoon. Figure 2.

Eponymy: from the Latin, tricolor, three-coloured, for the golden yellow flower with a maroon central eye and pale yellow in the throat and tube.

Distribution and ecology: Geissorhiza tricolor apparently has a very limited range southeast of Riversdale in southern Western Cape (Figure 3). The largest population occurs in the small Werner Frehse Nature Reserve a few kilometres east of Riversdale, where it is protected from disturbance. Plants grow in pebbly ironstone at the transition between renosterveld and fynbos-thicket.

Diagnosis and relationships: according to available records Geissorhiza tricolor was discovered in September 2006 during a botanical survey of the site of a new housing development at Riversdale. A collection made by N.A Helme alerted us to the existence of the plant, which we re-collected in early October. The species is unique in Geissorhiza in its deep yellow flowers with exceptionally broad tepals and a dark, maroon-black central eye. The perianth tube is very short in comparison, $3-4 \mathrm{~mm}$ long. The species recalls $G$. inconspicua and $G$. foliosa in vegetative morphology but the flowers are larger than in both of these species and very different in coloration. Geissorhiza foliosa has pink to light purple flowers with a tube $\pm 5 \mathrm{~mm}$ long and tepals $13-17 \mathrm{~mm}$ long, and $G$. inconspicua has blue-violet, pink or white flowers with a perianth tube $4-6 \mathrm{~mm}$ long and tepals 8 11 , rarely up to $15 \mathrm{~mm}$ long.

The flowers of Geissorhiza tricolor closely resemble those of orange-flowered Ornithogalum dubium which blooms together with it in the Werner Frehse Nature Reserve and we assume that both species are pollinated

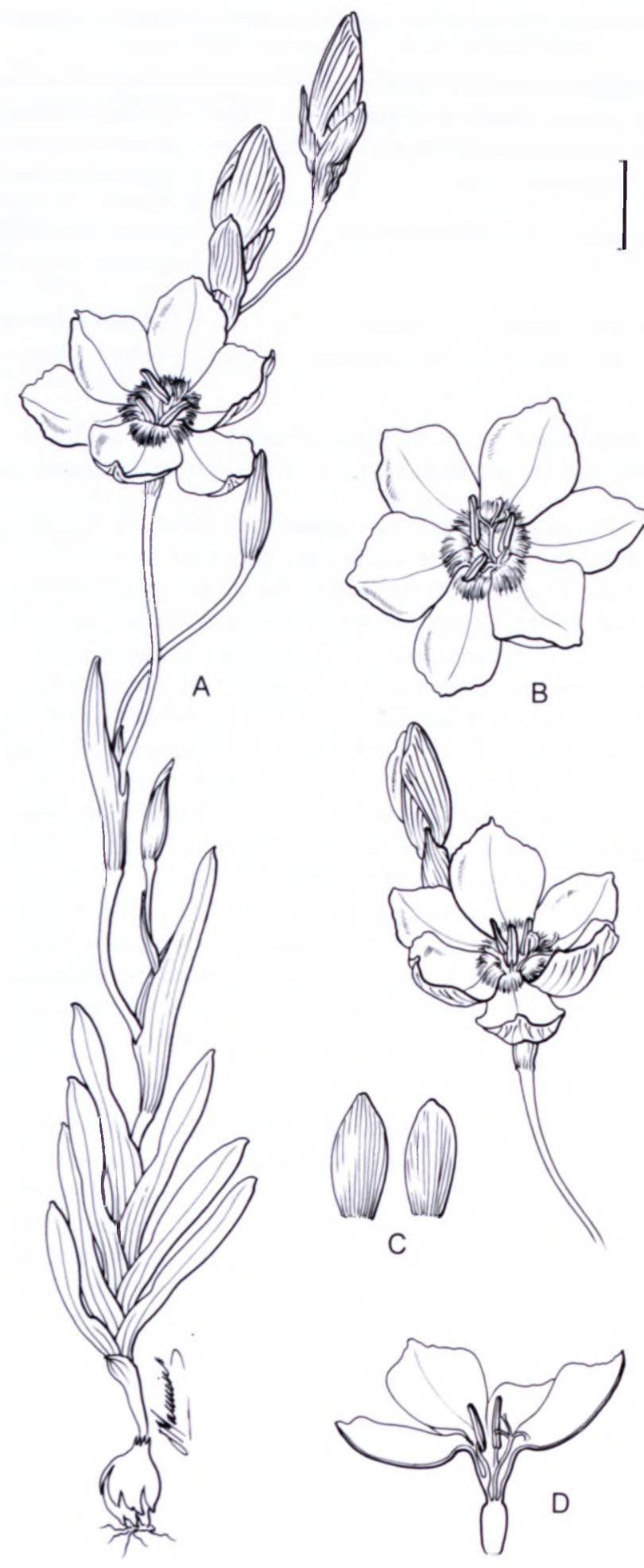

FIGURE 2.-Geissorhiza tricolor. Manning $307 /$ (NBG). A. flowering plant: B, flowers; C. outer (left) and inner (right) floral bracts; D). half-flower. Scale bar: $10 \mathrm{~mm}$. Artist: J.C. Manning.

by the same suite of hopliine beetles. No hopliines or other potential pollinators have so far been recorded on $G$. tricolor or $O$. dubium at that locality but the latter species has been found to be pollinated by hopliine beetles at other sites (Goldblatt et al. 1998).

\section{Additional specimens examined}

WESTERN CAPE.-3421 (Riversdale): southern Edge of Riversdale, Rooidam, east of $\mathrm{N} 2$, stony well-drained loam, in renosterveld, (-AB), 22 September 20(K), Helme 4193 (NBG). 


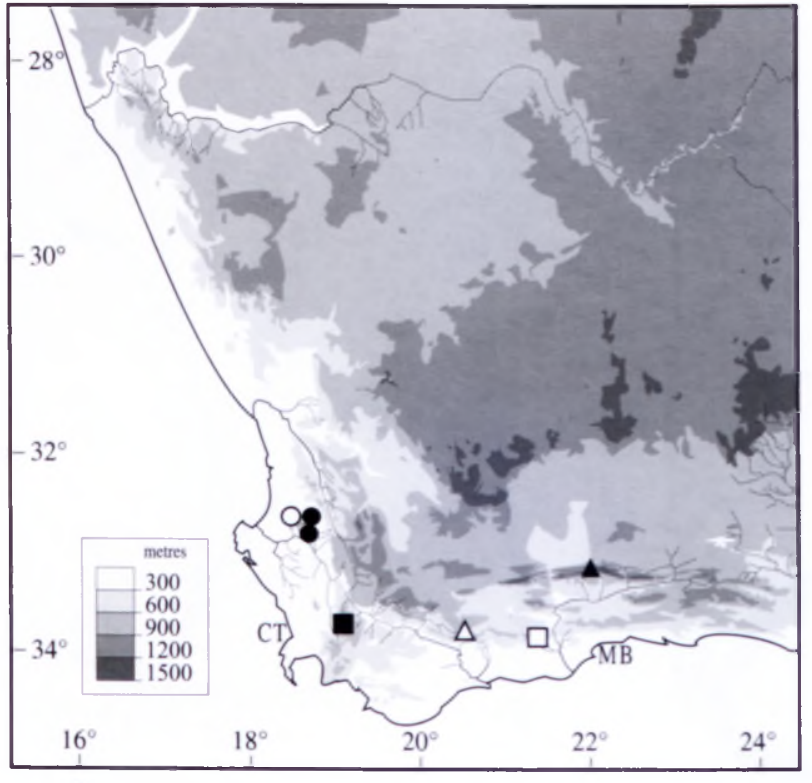

FIGURE 3.-Known distribution of Geissorhiza alrimonlana, $\triangle: G$. helmei, $\mathrm{O} ; G$. monsicola. $\mathbf{\Delta}$; $G$. sufflava. 0; G. tricolor, $\square ; G$. lapidosa.

10. Geissorhiza altimontana Goldblatl \& J.C.Manning, sp. nov.

Plantae 60-120 mm altae, cormo tunicis manifeste concentricis, foliis 5 vel 6,4 inferiorbus basalibus prostratis lanceolatis $20-50 \times 2.5-6.0 \mathrm{~mm}$, spica 1- vel 2 -flora, bracteis viridibus ad apicem rubris $7-10 \mathrm{~mm}$ longis, floribus actinomorphis carneis, perianthii tubo $7-8 \mathrm{~mm}$ longo \pm cylindrico, tepalis subaequalibus oblongis $\pm 14 \times 6$ $\mathrm{mm}$, filamentis $\pm 8 \mathrm{~mm}$ longis aequalibus, antheris \pm 4 $\mathrm{mm}$ longis, ramis styli recurvatis $\pm 1.3 \mathrm{~mm}$ longis.

TYPE.--Western Cape, 3320 (Montagu): Langeberg. upper slopes of Leeuriviersberg, $300 \mathrm{~m}$ east of peak, 1550 m, (-CD), I5 January 2006, Helme 3778 (NBG, holo.).

Plants $60-120 \mathrm{~mm}$ high including flowers, stem base sheathed underground by a collar of dry, persistent leaf bases, and above ground by dry cataphylls. Corm ovoid. $4.6 \mathrm{~mm}$ diam., tunics soft-textured, light brown, evidently concentric, becoming fibrous and not accumulating with age. Stem erect or sometimes horizontal at ground level for a short distance, unbranched, smooth. Leaves 5 or 6 , lower 4 basal, spreading horizontally and \pm prostrate, blades lanceolate, leathery, 20-50 × 2.5-6.0 mm, margins moderately thickened, cauline leaves 1 or 2, shorter than basal leaves and sheathing for half their length. Spike erect. \pm straight. 1- or 2-flowered; bracts green with red tips, 7-10 mm long. outer obtuse, inner notched apically. Flowers radially symmetric with tepals ascending. pink but \pm greenish in throat. unscented; perianth tube \pm cylindric, $7-8 \mathrm{~mm}$ long: tepals subequal, oblong, $\pm 14 \times 6 \mathrm{~mm}$, ascending and forming a wide cup. Stamens: filaments $\pm 8 \mathrm{~mm}$ long. equal; anthers $\pm 4 \mathrm{~mm}$ long, sagittate at base for $\pm 1 \mathrm{~mm}$. yellow, pollen yellow. Ovary ovoid, $\pm 2.5 \mathrm{~mm}$ long; style slender. dividing opposite anther apices, style branches slightly recurved and arching over anthers, $\pm 1.3 \mathrm{~mm}$ long. Capsules and seeds unknown. Flowering time: January. Figure 4

Eponymy: from Latin alti, high, montamus, mountains. referring to the habitat.
Distribution and ecology: known from just one collection on Leeuriviersberg (Grootberg) west of Swellendam, Geissorhiza altimontana occurs at high elevations in the Langeberg at $\pm 1550 \mathrm{~m}$ (Figure 3). Plants were collected in unburned veld, growing on damp. mossy ledges on steep, south-trending slopes. The area is exposed to frequent summer cloud from southeast trade winds, making flowering of this soft geophyte possible in a region of predominantly summer drought.

Diagnosis and relationships: with its five or six, relatively short leaves, the basal leaves spreading horizontally, the short stature and 1- or 2-flowered spikes, Geissorhiza altimontana appears most closely allied to the Swartberg species, G. nigromontana Goldblatt and G. uliginosa Goldblatt \& J.C.Manning. Geissorhiza uliginosa is essentially aquatic, growing in streams and waterfalls, and has reduced corms but $G$. nigromontana has a similar habitat to $G$. altimontana: damp, mossy ledges in shallow soil and south-facing slopes, and both species flower in the summer months of January and February. The longer perianth tube, 7-8 mm long, and tepals $\pm 14 \mathrm{~mm}$ long, readily separate $G$. altimontana from $G$. nigromomana, which has a very short perianth tube, 2-3 mm long, and longer tepals, 14-16 mm long.

\section{Geissorhiza monticola Goldblatt \& J.C.Man-} ning, sp. now.

Plantae $100-160 \mathrm{~mm}$ altae, cormo globoso $\pm 10 \mathrm{~mm}$ diam. tunicis concentricis atrobrunneis, foliis 4-7 inferioribus 2 vel 3 basalibus linearibus vel falcatis patentibus vel prostratis, caule filiformi flexuoso usque ad 4-ramoso, spica 1-flora, bracteis viridibus purpureo-suffusis $8-10 \mathrm{~mm}$ longis marginibus membranaceis, floribus zygomorphis caeruleo-malvinis, perianthii tubo infundibuliformi $\pm 3 \mathrm{~mm}$ longo leviter curvato, tepalis anguste oblongis obtusis patentibus $14-18 \times 4.0-5.5$ $\mathrm{mm}$. filamentis unilateralibus declinatis $7-9 \mathrm{~mm}$ longis, antheris 3-4 mm hebetate roseis, stylo prope antherarum apices diviso ramis $3-4 \mathrm{~mm}$ longis recurvatis.

TYPE.-Western Cape, 3321 (Ladismith): Swartberg, road to Gamkakloof, (-BD), 10 September 2001, Goldblatt \& Porter 11872 (NBG, holo.; MO, iso.).

Plants 100-160 mm high. Corm globose, asymmetric with oblique, flattened side, $\pm 10 \mathrm{~mm}$ diam., tunics concentric, dark brown, fragmenting into vertical sections. Stem filiform, flexuose, with up to four, 1-flowered branches from axils of cauline leaves. Leaves $4-7$, softtextured. lower 2 or 3 basal and \pm half as long as stem. spreading to prostrate, blades linear to falcate, plane with slightly thickened and raised central vein, $2-3 \mathrm{~mm}$ wide. upper leaves cauline, decreasing in size upward, partly to entirely sheathing. Inflorescence: flowers solitary on branches; bracts green, soft, flushed purple, margins membranous, transparent, 8-10 mm long, inner slightly shorter than outer. Flowers zygomorphic, facing to side with tepals held vertically, blue-mauve with greenish cream throat edged with dark blue; perianth tube funnelshaped, slightly curved, $\pm 3 \mathrm{~mm}$ long: tepals narrowly oblong, obtuse, spreading at right angles to tube, 14-18 $\times 4.0-5.5 \mathrm{~mm}$. inner slightly narrower than outer. Siamens unilateral and declinate; filaments $7-9 \mathrm{~mm}$ long. exserted for 7-8 mm: anthers $3-4 \mathrm{~mm}$ long, dull pink. 


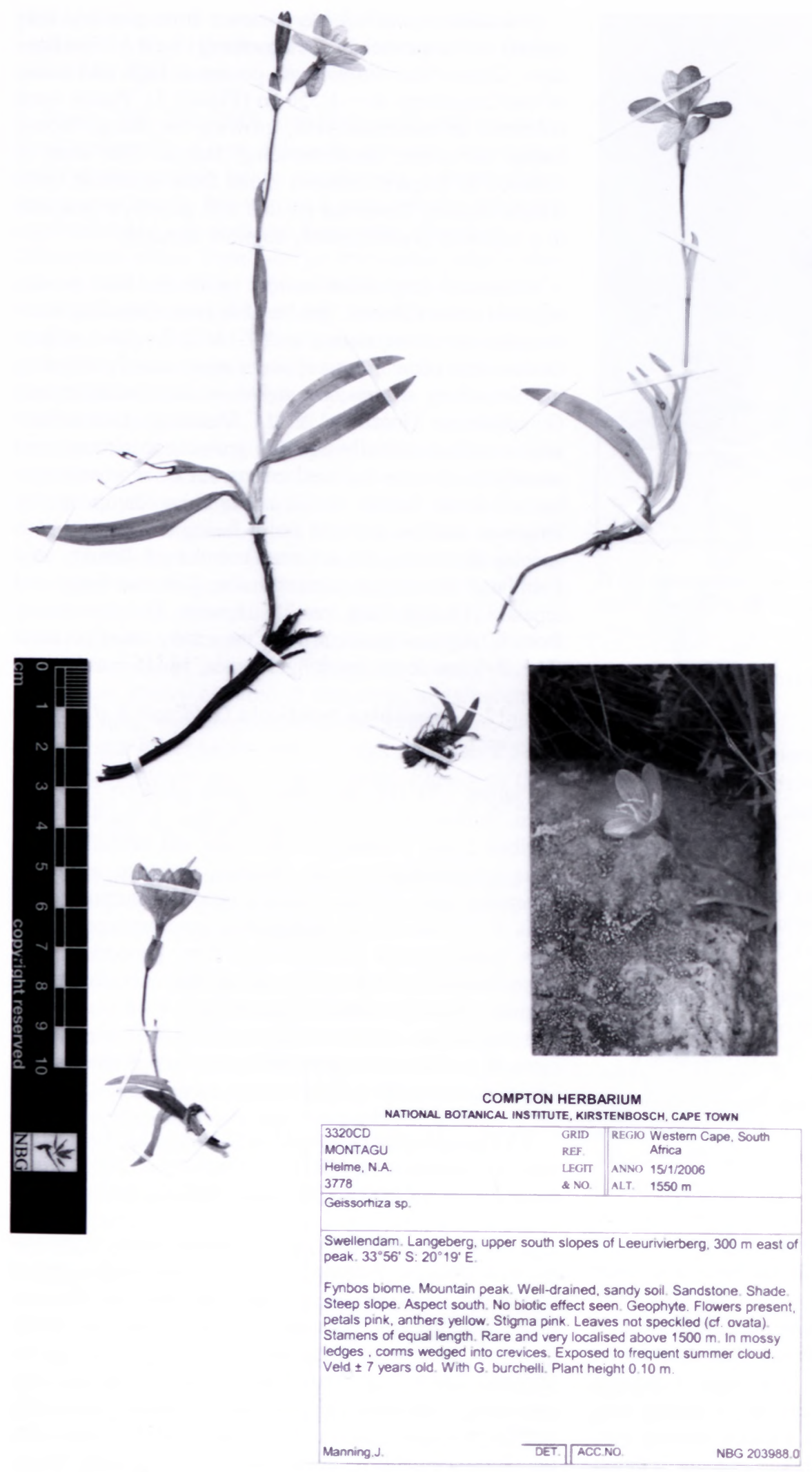

FIGURE 4.-Geissorhiza altimontana. Helme 3778 (NBG)

Ovary $\pm 3.5 \mathrm{~mm}$ long; style dividing near apex of anthers, style branches 3-4 mm long, recurved. Capsules and seeds unknown. Flowering time: September. Figure 5.

Eponymy: from Latin, meaning growing in the mountains.

Distribution and ecology: the only known population of Geissorhiza monticola is from the central Swartberg, west of Swartberg Pass (Figure 3). Plants grow on south-trending, rocky sandstone slopes in pockets of peaty sand.
Diagnosis and relationships: Geissorhiza monticola is distinguished by solitary flowers with large, blue, zygomorphic flowers facing to the side, very short perianth tube and well-exserted, declinate stamens. Its relationships presumably lie with $G$. delicatula Goldblatt of the Langeberg and Swartberg and its allies, with which it shares an oblique corm, several plane leaves with the marginal vein set slightly away from the margin itself, herbaceous bracts, and solitary flowers. Geissorhiza delicatula, known to us only from dried specimens, has much smaller, cup-shaped 


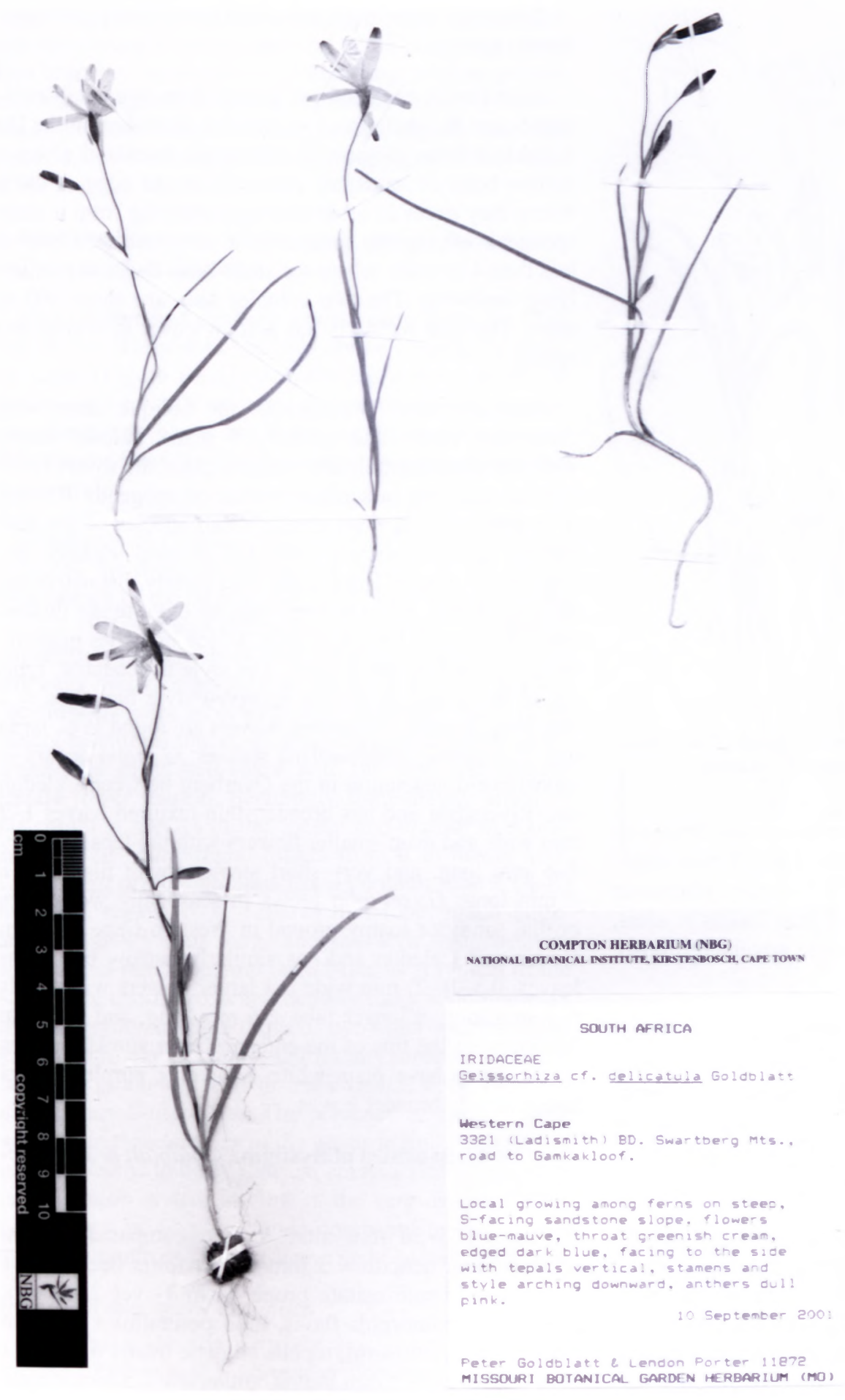

FIGURE 5.-Geissorhiza monticola, Goldblatt \& Porter 11872 (NBG).

flowers that are held upright, with elliptical or obovate, pale mauve tepals mostly 7-10 mm long, erect stamens with filaments 3-5 mm long, and a central style of similar length with short style branches up to $1.5 \mathrm{~mm}$ long, thus less than half as long as in G. monticola. Geissorhiza nigromontana may also be confused with $G$. monticola but it has a stem \pm prostrate toward the base, a spike of 2 or 3 flowers (flowers always in $G$. monticola), bears cormlets in the leaf axils, shorter leaves with blades $4-10 \mathrm{~mm}$ wide (vs 2-3 mm in G. monticola) and the flowers are, as far as known (Goldblatt 1985), upright and radially symmetric.

The flowers of Geissorhiza monticola bear a remarkable similarity to those of $G$. grandiflora in their orientation, shape, and in the well-exserted, declinate stamens and style but this similarity is presumably due to convergence. $G$. grandiflora from the southwestern coastal mountains has leaves with prominently thickened margins and main vein, and is thus 2-grooved on each surface, has (1-)3-8-flowered spikes, and longer floral tubes, 10-22 $\mathrm{mm}$ long.

\section{Geissorhiza lapidosa Goldblatt \& J.C.Man-} ning, sp. nov.

Plantae \pm acaulescentes $20-40 \mathrm{~mm}$ altae eramosae, cormo 4-5 mm diam., tunicis concentricis lignosis nigrescentibus, foliis 4 laminis lineari-falcatis crassis coriaceis glaucis marginibus saepe rubrescentibus ad $50 \times 0.5-1.0 \mathrm{~mm}$, folio supremo vaginanti, spica $1-\mathrm{vel}$ 2-flora, bracteis coriaceis glaucis ovatis bractea exteriori $4-5 \mathrm{~mm}$ longa, interiori ad apicem furcata, floribus 


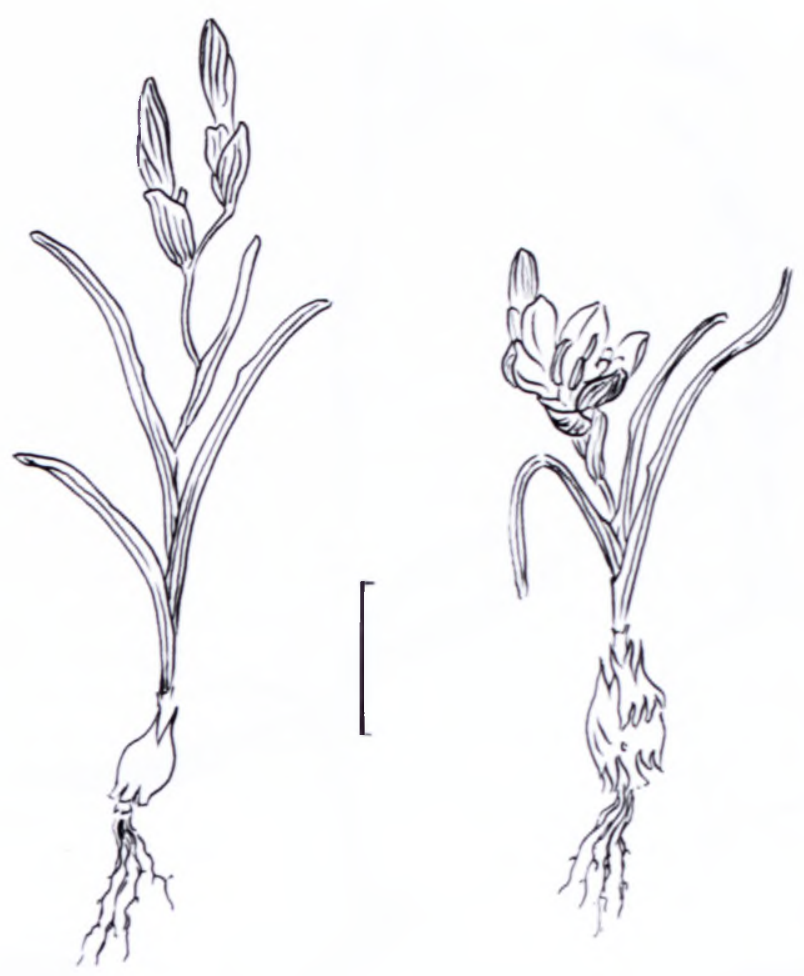

FIGURE 6.-Geissorhiza lapidosa, Helme \& Turner 5747 (NBG), whole plants. Scale bar: $10 \mathrm{~mm}$. Artist: J.C. Manning.

actinomorphis albis tepalis exterioribus extus rubro-carneis, tubo perianthii infundibuliformi $2.0-2.5 \mathrm{~mm}$ longo, tepalis patentibus oblanceolatis $\pm 6 \times 2 \mathrm{~mm}$. filamentis $3.5-4 \mathrm{~mm}$ longis, antheris $1.5-2.0 \mathrm{~mm}$ longis \pm albis, stylo dimidium inferiorem antherarum adversum diviso, ramis $1.5-2 \mathrm{~mm}$ longis.

TYPE.-Western Cape, 3319 (Worcester): Du Toitskloof Mtns, Goudini Sneeukop, western and southern edges of shale band, 1 700-1730 m, seasonally damp. shallow moss and shale-derived silt overlying sandstone shelf, rare and localized, (-CC), 9 November 2008 , Helme \& Turner 5747 (NBG, holo.).

Plants \pm acaulescent, $20-40 \mathrm{~mm}$ high, unbranched with stem smooth, flushed red, not or barely extending above ground. Corm obliquely ovoid with narrow flat side, $4-5 \mathrm{~mm}$ diam., tunics woody, dark. blackish, concentric. Leaves 4, lower two basal, third leaf inserted at or shortly above ground, blades linear-falcate, exceeding the spike. $0.5-1.0 \mathrm{~mm}$ wide, thick and leathery, elliptical in section when fresh, glabrous, glaucous with margins often reddish, uppermost leaf cauline and bladeless. Spike 1- or 2-flowered; bracts leathery and glaucous flushed reddish but submembranous and finely flecked with brownish red along margins, broadly ovate, outer truncate or obscurely tricuspidate, 4-5 mm long, inner as long or slightly shorter, notched at apex. Flowers actinomorphic, white with outer tepals reddish pink on reverse; perianth tube funnelshaped, 2.0-2.5 mm long; tepals subequal, oblanceolate, $\pm 6 \times 2 \mathrm{~mm}$. Stamens with filaments $3.5-4.0 \mathrm{~mm}$ long, white; anthers $1.5-2.0 \mathrm{~mm}$ long, \pm white. Ovary obovoid. $\pm 2.5 \mathrm{~mm}$ long; style displaced to one side, dividing opposite lower half of anthers, $\pm 4 \mathrm{~mm}$ long, branches long and recurved, 1.5-2.0 mm long. Capsules and seeds unknown. Flowering time: November. Figure 6.
Eponymy: from the Latin, lapidosus, stony or rocky, for the habitat.

Distribution and ecologv: known from two small colonies below the shale band on Goudini Sneeukop in the Du Toitskloof Mtns (Figure 3). Plants are localized along a narrow band of sandstone pavement at the edge of cliffs where they occur in moist seepages draining from a shale sponge overlying the sandstone, a very restricted habitat less than $4 \mathrm{~m}$ wide, where the shale band meets the underlying sandstone. The two colonies seen are about $800 \mathrm{~m}$ apart. The area regularly has a snow cover in winter and spring.

Diagnosis and relationships: the oblique corm with concentric tunics and smooth. \pm plane, falcate leaves with the uppermost clearly cauline, place the dwarf Geissorhiza lapidosa in section Weihea of subgenus Weihea. It is distinguished from similar small species of the section by its high montane habit and unusual leathery, falcate leaves at most $1 \mathrm{~mm}$ wide. Particularly distinctive are the short-tubed, white flowers with the outer tepals flushed reddish pink and the short style, which branches opposite the lower half of the anthers. The style is eccentric, typical of the genus, as are the recurved style branches, \pm 2 $\mathrm{mm}$ long. Similar, bicoloured flowers are found in $G$. nana and $G$. setifolia, both lowland species: $G$. nana occurs in renosterveld vegetation in the Overberg between Caledon and Riversdale and has broader, thin-textured leaves 1-2 $\mathrm{mm}$ wide and even smaller flowers with the tepals mostly 3-6 mm long, and very short stamens with filaments \pm $2 \mathrm{~mm}$ long; $G$. setifolia grows in seasonally wet places on flat sandy or loamy ground in Western Cape between Gouda and Caledon and has similarly narrow but linear leaves, $0.5-1(-2) \mathrm{mm}$ wide but larger flowers with tepals 6-8 $\mathrm{mm}$ long, a longer tube $\pm 6 \mathrm{~mm}$ long, and the style branching at the tips of the anthers. Other similar species in the group have plain white, mauve or purple flowers and generally broader leaves.

19. Geissorhiza platystigma Goldblatt \& J.C.Manning, sp. nov.

Plantae 25-50 mm altae, cormo campanulato basi ad marginem dentato $\pm 3 \mathrm{~mm}$ diam., foliis linearibus \pm $1 \mathrm{~mm}$ latis, caule usitate prope basin 1-vel 2-ramoso, floribus actinomorphis flavis, tubo perianthii $\pm 1.5 \mathrm{~mm}$ longo infundibuliformi, tepalis anguste ovatis $6-7 \times \pm 3$ $\mathrm{mm}$, filamentis $\pm 2 \mathrm{~mm}$ longis, antheris $\pm 1.5 \mathrm{~mm}$ longis, ramis styli $\pm 1.5 \mathrm{~mm}$ longis prominenter villosis.

TYPE.-Western Cape, 3318 (Cape Town): gravelly, gently north-facing slopes in Darling Nature Reserve, (-AC), 22 September 1999, Goldblatt \& Nänni l/162.A (NBG, holo.: MO, iso.).

Plants 25-50 mm high. Corm bell-shaped, $\pm 3 \mathrm{~mm}$ diam. at widest, basal margin toothed, tunics light brown, concentric, woody. Stem usually 1- or 2-branched from near base. Leaves linear, $\pm 1 \mathrm{~mm}$ wide, sheaths inflated. plane, \pm as long as stem. Main and lateral spikes 1 -flowered; bracts green or flushed purple distally, outer \pm 8 $\mathrm{mm}$ long, inner $\pm 6 \mathrm{~mm}$ long, not forked at apex. Flowers actinomorphic, upright, pale yellow, unscented: perianth tube funnel-shaped, $\pm 1.5 \mathrm{~mm}$ long: tepals narrowly ovate, $6-7 \times \pm 3 \mathrm{~mm}$. Stamens erect, equal; filaments \pm 
$2 \mathrm{~mm}$ long; anthers $\pm 1.5 \mathrm{~mm}$ long, pale yellow. Ovary with style erect, dividing opposite upper third of anthers, style branches recurved, $\pm 1.5 \mathrm{~mm}$ long, bearing prominent hairs longer than width of branch. Capsules barrelshaped, $\pm 5 \mathrm{~mm}$ long. Seeds \pm globose, slightly less than I mm diam. Flowering time: September, probably also in late August. Figure 7.

Eponymy: from the Greek, platy, broad, for the unusually broad style branches.

Distribution and ecologv: known only from the Darling Nature Reserve in the hills above Darling in Western Cape (Figure 8), Geissorhiza platystigma grows in granite-derived soils on east- and north-trending slopes. The diminutive plants are found locally in open ground or in the shade of low shrubs in Elytropappus-dominated renosterveld.

Diagnosis and relationships: Geissorhiza platystigma is one of the most inconspicuous species in the genus. Each branch of the stem is just $30-50 \mathrm{~mm}$ high and bears a single flower. Most distinctive are the style branches, which are short and broad and densely covered in prominent hairs much longer than the width of the style branch. The flowers are otherwise unremarkable. The corm closely resembles that of $G$. ornithogaloides subsp. ornithogaloides in its bell shape with flat base and sharply dentate lower margin. Seemingly immediately allied to this common species of the coastal and interior of southern Cape. G. platystigma differs from it in flower size. Geissorhiza ornirhogaloides has a perianth tube 2-3(-4) $\mathrm{mm}$ long, tepals $(6-) 7-12(-18) \mathrm{mm}$ long. much larger anthers $3.0-4.5 \mathrm{~mm}$ long, and the style branches are slender, $2-3 \mathrm{~mm}$ long, and thread-like as is typical of the genus. The short, broad and densely hairy style branches of $G$. platystigma recall those of two other species of the genus from the Darling-Malmesbury area of Western Cape, $G$. mathensii and $G$. eurystigma, both members of subgenus Geissorhiza. The presence of unusual style branches in three species of the genus in this small part of its range seems to be an unusual coincidence unrelated to its pollination system in view of the very different floral morphology of $G$. planstigma compared to larger. blue and red perianth of $G$. eurvstigma and $G$. mathewsii.

\section{Additional specimens examined}

WESTERN CAPE.-3318 (Cape Town): gravelly slopes in Darling Nature Reserve, (-AC), 3 September 1999. Linlewort s.n. (MO). 12 September 2(x)8, Goldhlatl \& Porter 1320) (MO. NBGi).

41. Geissorhiza sufflava Goldblan \& J.C.Manning. sp. nov.

Plantae $100-150 \mathrm{~mm}$ altae foliis exclusis, cormo globoso $\pm 8 \mathrm{~mm}$ diam., tunicis pallide brunneis concentricis, caule eramoso, foliis ( 2 vel) 3 imo longiore saepe spicam excedenti, laminis teretibus anguste 4 -sulcatis, spica forte flexuosa 1-vel 2-flora, bracteis \pm siccis pallide translucente-brunneis $12-16 \mathrm{~mm}$ longis, floribus cupulatis pallide flavis in centro brunneolis, tubo perianthii infundibuliformi $7-9 \mathrm{~mm}$ longo, tepalis anguste ovatis $18-25 \times 6.0-8.5 \mathrm{~mm}$, filamentis $12-14 \mathrm{~mm}$ longis per $10-12 \mathrm{~mm}$ exsertis, antheris $\pm 5 \mathrm{~mm}$ longis flavis, ramis styli $\pm 5 \mathrm{~mm}$ longis.

TYPE.-Western Cape, 3218 (Clanwilliam): Piketberg. lower slopes of Versfeld Pass, light stony clay in

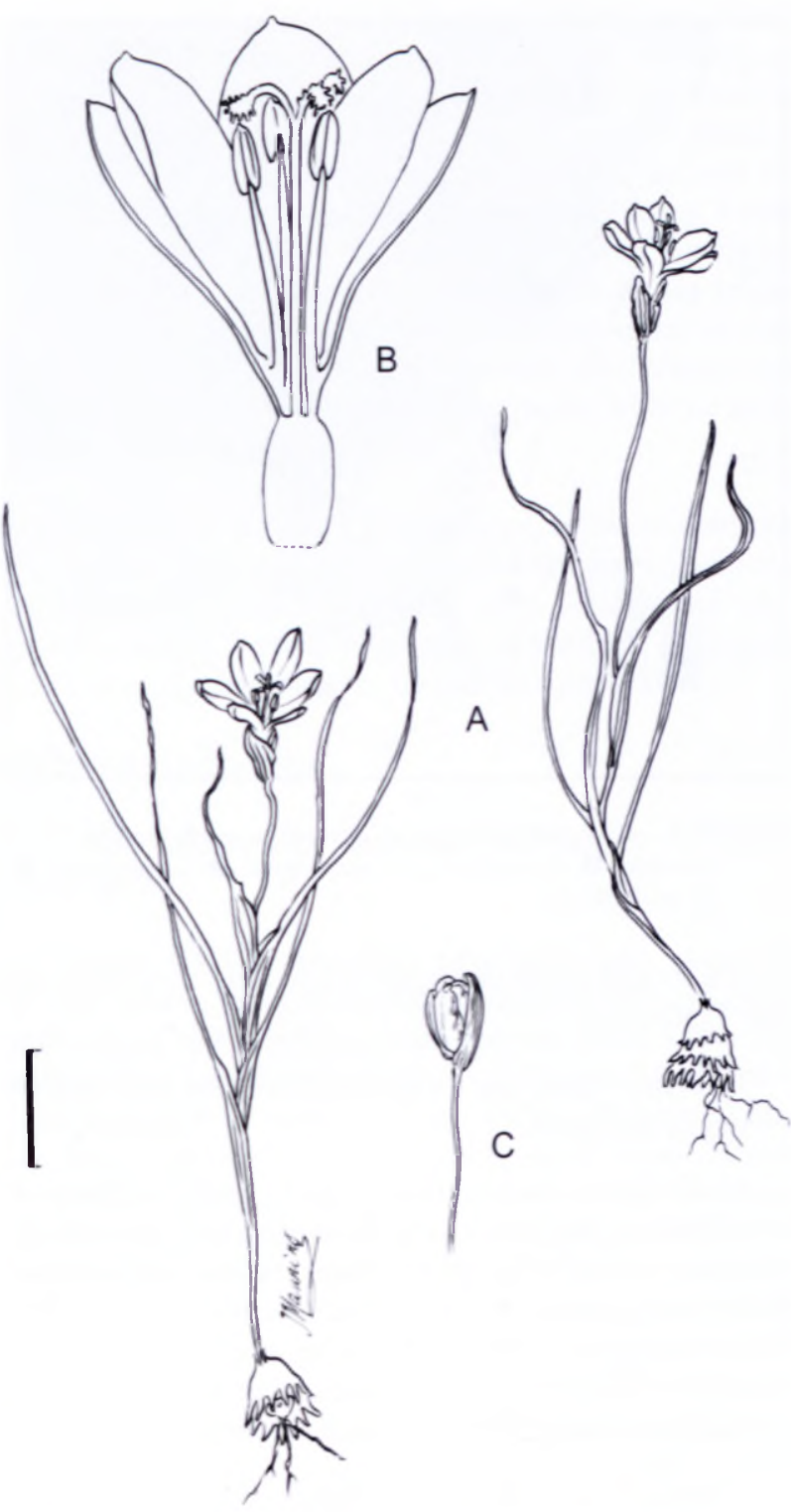

FIGURE 7.-Geissorhiza planystigma. Goldblatt \& Porter 13202 (NBG). A. flowering plants: B. half-flower: C, capsule. Scale bar: A. C. $10 \mathrm{~mm}$; B, $2.5 \mathrm{~mm}$. Artist: J.C. Manning.

renosterveld. (-DC). 22 September 1992, Goldhlatt \& Mamning 9468 (NBG, holo.; MO, PRE, iso.).

Plants 100-150 mm high, not including leaves. Corm globose, $\pm 8 \mathrm{~mm}$ diam., tunics light brown, concentric, splitting longitudinally and drawn into short bristles above. Stem simple, smooth, erect below, flexed outward above sheaths of upper two leaves. Leaves 3 , rarely 2 , lowermost longest, often exceeding spike, up to $300 \mathrm{~mm}$ long, uppermost inserted in middle of stem, blades terete with 4 narrow, longitudinal grooves, $0.5-1.0 \mathrm{~mm}$ diam. Spike strongly flexuose, inclined and flowers borne on upper side, (1)2- or 3-flowered; bracts \pm dry, light brown-translucent, 12-16 mm long, inner slightly shorter than outer, with two main veins and apex bilobed. Flowers cup-shaped, pale clear yellow, brownish in centre, drying pale yellow, unscented; perianth tube funnel-shaped, 7-9 mm long: tepals narrowly ovate, $18-25 \times 6.0-8.5 \mathrm{~mm}$. Stamens: filaments $12-14$ $\mathrm{mm}$ long, exserted for 10-12 $\mathrm{mm}$; anthers $\pm 5 \mathrm{~mm}$ long, yellow. Ovary ovoid, $\pm 3 \mathrm{~mm}$ long: style dividing opposite upper third of anthers, style branches $\pm 5 \mathrm{~mm}$ long. 




FIGURE 8.-Known distribution of Geissorhiza cantharophila, $\square ; G$. demissa, $\mathbf{Q}$; exilis, $\triangle$; $G$. platystigma, O Geclinata, G. saricola, $\mathrm{O}$.

Capsules and seeds unknown. Flowering time: September. Figure 9.

Eponymy: from the Latin, sufflaris, the pale yellow colour of the tepals.

Distribution and ecology: Geissorhiza sufflava is restricted to the lower eastern slopes and foot of the Piketberg range (Figure 3). Plants favour well-drained stony clay ground in renosterveld or renosterveld-fynbos transition and flower best after fire but continue to bloom for several years thereafter, until the surrounding shrubby vegetation forms a closed canopy.

Diagnosis and relationships: spikes of 1 or 2, large, pale yellow, cup-shaped flowers and the terete, four-grooved leaves, set Geissorhiza sufflava apart in section Angustifolia Goldblatt of subgenus Weihea. It has the typical, light brown, concentric corm tunics of the subgenus and falls closest to the widespread, small-flowered $G$. juncea (Link) D.Dietr. and the southwestern Cape endemic $G$. furva Banks ex Ker Gawl., both of which have similar, terete, four-grooved leaves. Of the two, G. furva has deep yellow flowers with a shorter perianth tube 3-5 mm long and tepals $15-22(-28) \times 5-8(-9) \mathrm{mm}$, that spread \pm at right angles to the tube when fully open, thus usually smaller and with a different orientation from those of $G$. sufflava. Even on warm days, the tepals of the often larger flowers of $G$. sufflava remain cupped rather than outspread. The two species appear to differ in ecology and distribution, and $G$. furva is endemic to the Swartland south of the Piketberg, between Hermon and Paarl, where it occurs in seasonally waterlogged clay flats. A curious feature of $G$. furva with an evident biochemical basis is that the tepals turn brownish when dry, often with a dull, metallic grey sheen, whereas those of $G$. sufflava retain their pale colour when dry.

\section{Additional specimens examined}

WESTERN CAPE.-3220 (Clanwilliam): $24 \mathrm{~km}$ north of Piketberg. Farm Kliprivier, (-DB), well-drained stony soil, $150 \mathrm{~m}, 6$ September 2002. Helme 2270 (NBG); Piketherg, lower slopes of Versfeld Pass, (-DC), 23 September 1999, Goldblast III66.4 (M()).

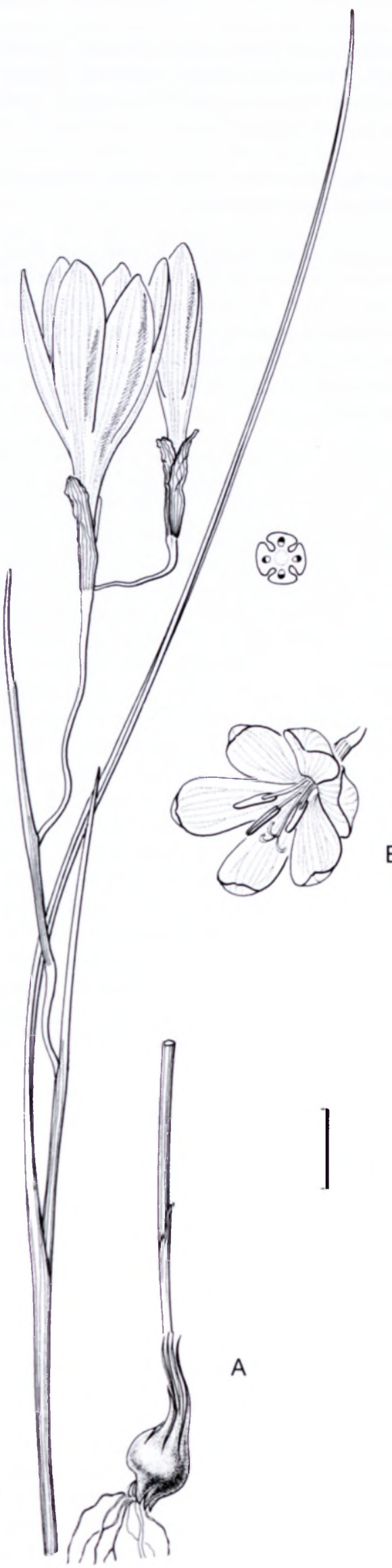

FI(iURE 9.-Geissorhiza sufflava. Goldblatt \& Manning 9468 (NBG) A. flowering plant with leaf $\mathrm{U}$ s (much enlarged): B. flower. Scale har: $10 \mathrm{~mm}$. Artist: J.C. Manning. 
48. Geissorhiza helmei Goldblatt \& J.C.Manning, sp. nov.

Plantae $80-150 \mathrm{~mm}$ altae, cormo ovoideo 10-15 $\mathrm{mm}$ diam., tunicis concentricis pallide brunneis, foliis usitate 3 , imo basali lamina $10-15 \times 3-4 \mathrm{~mm}$ marginibus incrassatis alatisque extus glutinosis costa centrali incrassata marginibus alatis ciliatis, caule laevi suberecto usitate 1-ramoso, spica leviter flexuosa secunda 7-ad 10flora ramis paucifloris, bracteis viridibus rubrovenosis marginibus membranosis 5-6 mm longis, floribus actinomorphis carneis inodoris, tubo perianthii $\pm 6 \mathrm{~mm}$ longo infundibuliformi, tepalis subaequalibus oblongis $\pm 12 \times$ $5 \mathrm{~mm}$, filamentis $\pm 6 \mathrm{~mm}$ longis, antheris $\pm 4 \mathrm{~mm}$ longis atropurpureis, ramis styli $\pm 2 \mathrm{~mm}$ longis.

TYPE.-Western Cape, 3218 (Clanwilliam): Piketberg, Farm Kleigat, lower slopes SE of Melkhoutkop. above track to Farm Weltevrede, burned the previous summer, 183 m, (-DA), 26 September 2006, Helme 4200 (NBG, holo.).

Plants 80-150 mm high. Corm ovoid, 10-15 mm diam., tunics concentric, light brown, fragmenting vertically into segments tapering upward into short spines. Stem smooth, flexed outward above sheath of second leaf, suberect, usually with 1 branch, flexed at base of first flower. Leaves usually 3 , lowermost basal, with a long. linear blade, 10 $15 \times 3-4 \mathrm{~mm}$, margins thickened and raised into wings extended at right angles and ciliate along edges, sticky outside and with sand adhering. central vein also thickened and with winged, ciliate edges, plane and pale-coloured between margins and central vein, upper leaves similar but smaller, uppermost leaf sometimes subtending a branch. Spike horizontal, lightly flexuose, with flowers borne on upper side, main spike 7-10-flowered, branches with fewer flowers; bracts suberect, held \pm at right angles to spike axis, green with red-flushed veins, margins membranous, outer $\pm 6 \mathrm{~mm}$ long, inner $\pm 1 \mathrm{~mm}$ shorter and forked apically. Flowers radially symmetric, pink, unscented; perianth tube funnel-shaped, $\pm 6 \mathrm{~mm}$ long; tepals subequal, oblong, \pm 12 $\times 5 \mathrm{~mm}$, spreading at right angles to tube. Stamens: filaments equal, $\pm 6 \mathrm{~mm}$ long; anthers $\pm 4 \mathrm{~mm}$ long, sagittate at base, dark purple, pollen brown. Ovary globose, $\pm 2 \mathrm{~mm}$ diam.; style suberect, dividing opposite middle third of anthers, style branches arched, $\pm 2 \mathrm{~mm}$ long. Capsules and seeds unknown. Flowering time: late August to mid September. Figure 10.

Eponymy: named in honour of N.A. Helme, a Cape Town botanist, who discovered the species.

Distribution and ecology: Geissorhiza helmei is a narrow endemic of the lower northern slopes of the southern arm of the Piketberg (Figure 3 ), growing in rocky ground in light sandy loam overlying clay. Plants were collected in the spring of 2006 after a fire earlier in the year and the species seems to be an absolute pyrophyte - a search for plants in spring in the following year failed to produce a single specimen of the species.

Diagnosis and relationships: in its general aspect Geissorhiza helmei recalls species of section Engusiphon (G.J.Lewis) Goldblatt of the genus, all members of which have fairly large corms with concentric tunics, the fragments of which taper above into short bristles, and a single long basal leaf, always with thickened and winged margins and central vein, and with the surface of the margins glandular and with sand adhering to them (Goldblatt 1985). Most other members of this alliance have flowers with a longer perianth tube, but at least $G$. brevituba (G.J.Lewis) Goldblatt has a short tube, $\pm 8 \mathrm{~mm}$ long. thus comparable to the tube of $G$. helmei; however, $G$. brevituba, also restricted to the Piketberg, has larger flowers with tepals $25-30 \mathrm{~mm}$ long. The spike of this species typically has only 1 to 3 flowers, the stamens and style of which are unilateral and declinate, with the style dividing well beyond the anther tips.

The species is named in honour of its discoverer, the botanist N.A. Helme, who also made the first collections of two more species described here, Geissorhiza altimontana and $G$. tricolor, as well as the type collection of $G$. demissa, and brought them to our attention.

\section{Subgenus Geissorhiza}

\section{Geissorhiza demissa Goldhlant \& J.C.Man-} ning, sp. nov.

Plantae 60-120 mm altae raro 1-ramosae, cormo \pm 4 mm diam., tunicis imbricatis nigrescentibus, caule puberuloso sed subglabro infra spicam, foliis 4 , duobus inferioribus basalibus linearibus vel falcatis $0.7-1.0 \mathrm{~mm}$ latis marginibus costaque leviter incrassatis alatis ciliatis, folio supremo caulem vaginanti, spica 1- vel 2-flora, bracteis viridibus in dimidio superiore siccis brunnescentibusque, bractea externa $\pm 5 \mathrm{~mm}$ longa interna \pm 4 $\mathrm{mm}$ longa, floribus actinomorphis, albis pallide caeruleis infra venosis tepalis exterioribus caerulescentibus in dimidio distali. perianthii tubo $\pm 2 \mathrm{~mm}$ longo infundibuliformi, tepalis obovatis subaequalibus $\pm 7 \times 3.5 \mathrm{~mm}$, filamentis inaequalibus $\pm 3.5 \mathrm{~mm}$ longis, antheris \pm 2 $\mathrm{mm}$ longis, stylo breviter ultra antherarum apices diviso ramis recurvatis $\pm 0.5 \mathrm{~mm}$ longis.

TYPE.-Northern Cape, 3018 (Kamiesberg): upper SE slopes of Stalberg. $3 \mathrm{~km} \mathrm{~S}$ of Farm Welkom, among granite boulders, $1370 \mathrm{~m},(-\mathrm{AC}), 28$ October 2005 . Helme 3626 (NBG, holo.).

Plants delicate, 60-120 mm high, rarely with 1 short branch; stems puberulous but subglabrous below spike. Corm obliquely narrowly ovoid. $\pm 4 \mathrm{~mm}$ diam., with several cormlets at base, tunics woody, blackish, imbricate. Leaves 4. lower two basal, third leaf inserted shortly above ground, blades linear-falcate, reaching to about base of spike, $0.7-1.0 \mathrm{~mm}$ wide, margins and central vein lightly thickened and narrowly winged, glabrous, uppermost leaf cauline, largely to entirely sheathing. Spike 1- or 2-flowered: bracts green below, dry and brown in upper half to two thirds, outer $\pm 5 \mathrm{~mm}$ long, inner $\pm 4 \mathrm{~mm}$ long. Flowers actinomorphic, white with veins tinged blue below and reverse of outer tepals flushed blue in distal half; perianth tube funnel-shaped, $\pm 2 \mathrm{~mm}$ long: tepals subequal, obovate. $\pm 7 \times 3.5 \mathrm{~mm}$. Stamens unequal; filaments $\pm 3.5 \mathrm{~mm}$ long. uppermost $0.5 \mathrm{~mm}$ shorter, white: anthers $\pm 2 \mathrm{~mm}$ long. pollen \pm white. Ovary with style erect, dividing shorty beyond anthers, branches recurved, $\pm 0.5 \mathrm{~mm}$ long. Capsules and seeds unknown. Flowering time: late August to October. probably also in early November. Figure 11. 


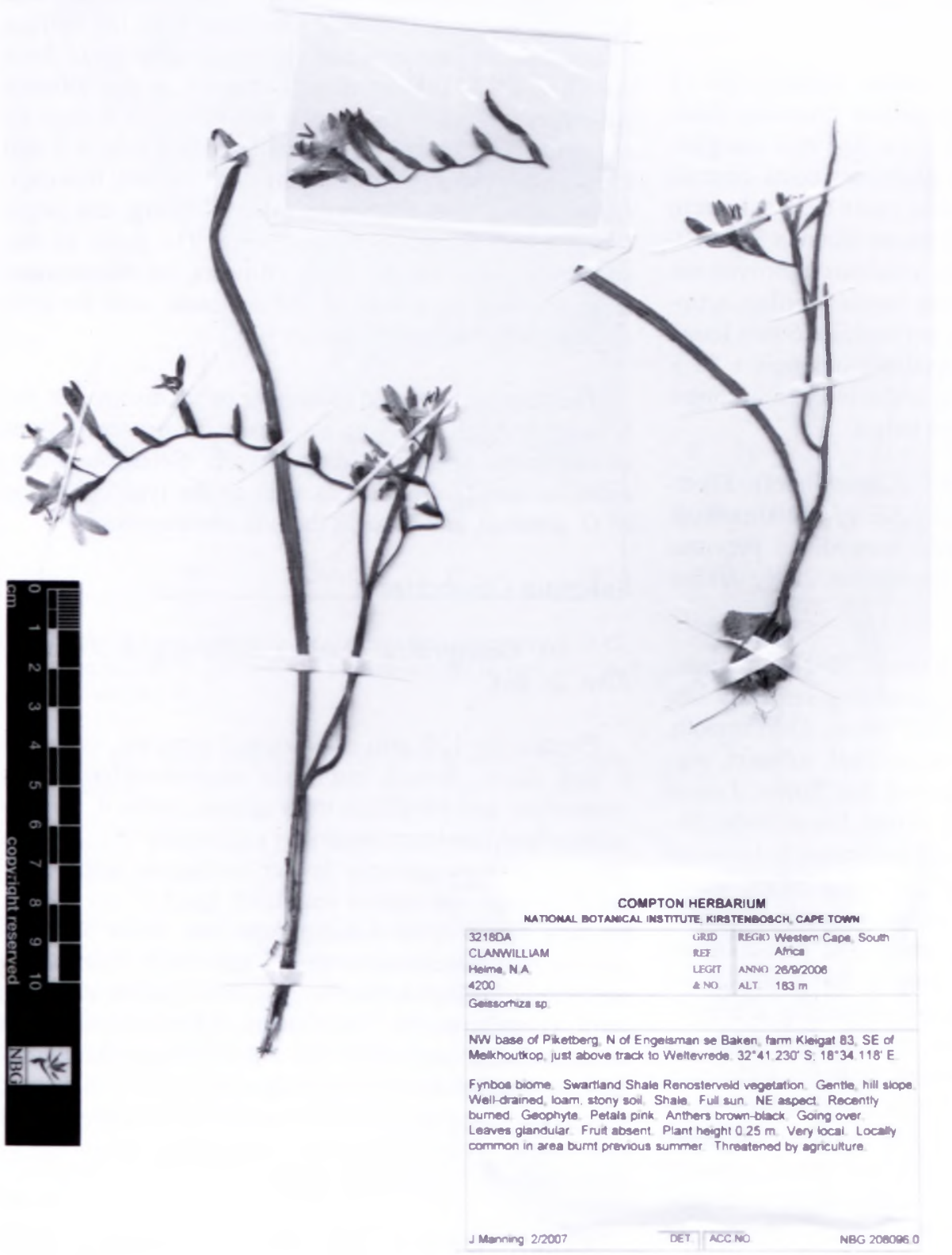

FIGURF. 10.-Geissorhiza helmei. Helme 4200) (NBC)
Eponymy: from the Latin, demissa, small in stature.

Distribution and ecologv: known from just three collections, one from the upper slopes of Stalberg in the Kamiesberg of central Namaqualand, and the other two from Western Cape, on the plateau of the Gifberg near Vanrhynsdorp and in the Cold Bokkeveld (Figure 8). Plants are localized and evidently uncommon in seasonally damp places in the shelter of granite boulders in the Kamiesberg or among sandstone rocks in the Western Cape mountains.

Diagnosis and relationships: imbricate corm tunics, \pm plane leaves with margins and central vein only lightly thickened, puberulous stem, and small, star-like flowers with unequal stamens, place $G$. demissa in the small section Planifolia Goldblatt of subgenus Geissorhiza (Goldblatt 1985), where it is remarkable for its small size and few-flowered spike. It is evidently closely allied to the widespread $G$. aspera, a variable species mostly with the flowers dark blue to violet although northern populations from the Cedarberg and Gitberg have white or bicoloured white and mauve flowers. Geissorhiza aspera is typically larger in all respects and almost invariably branched, with leaf blades 2-7 mm wide, 2-7-flowered spikes, and stems that are puberulous up to the base of the spike, even in the northern, white-flowered populations. The unbranched stems of $G$. demissa are subglabrous below the spike and the leaves are never more than $1 \mathrm{~mm}$ wide. Although the flowers of the two species are similar in shape, those of $G$. aspera are larger, with tepals $11-15 \times 46 \mathrm{~mm}$ and similar short filaments, 3-5 mm long, but longer anthers, 3-5 mm vs $\pm 2 \mathrm{~mm}$ long.

Geissorhiza aspera is common in the southwestern Cape, from Swellendam and Bredasdorp northwards to the Gitberg. It is absent from the Bokkeveld Mtns, a short distance to the north, where the morphologically similar $G$. inaequalis occurs, a more robust species with larger, purple flowers with declinate or horizontal stamens.

\section{Additional specimens examined}

WESTERN CAPE. -3118 (Vanrhynsdorp): Githerg, platcau ahoue pass. (-D)B), 23 August 1984. Goldhlant 7232 (MO). 3219 (Wuppertal): Cold Bokkeveld. Wagenbormsrivier, rocky slopes just northeast of Waterval, (-CC). 10 Oelober 2008. Helme 5876 (NBG) 

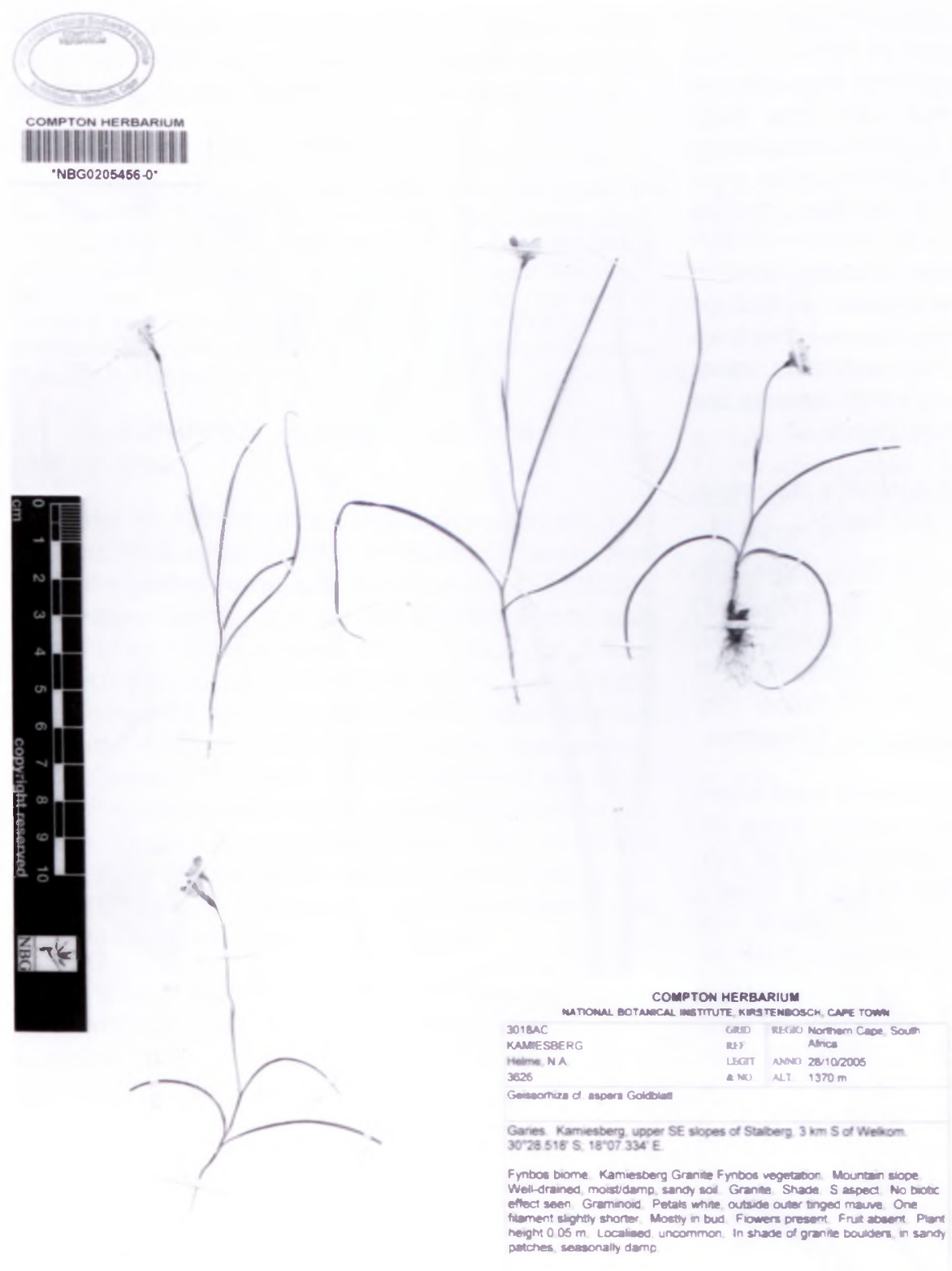

FIGURE 11.-Geissorhiza demissa. Helme 3626 (NBG).
90. Geissorhiza cantharophila Goldblatt \& J.C.Manning, sp. nov.

Plantae $250-450 \mathrm{~mm}$ altae, cormi tunicis imbricatis, foliis 3 duobus inferioribus laminis productis linearibus marginibus et costa incrassata alis ciliisque munitis, caule usitate 1-ad 3-ramoso, parce piloso, spica (3-ad) 5- vel 6-flora, bracteis inaequalibus bractea externa griseo-viridi $\pm 10 \mathrm{~mm}$ longa interna $\pm 8 \mathrm{~mm}$ longa membranacea atroviridi bicarinata ad apicem furcata, floribus actinomorphis, nitide carneis in centro atropurpureis, perianthii tubo $2.0-2.5 \mathrm{~mm}$ longo infundibuliformi, tepalis ovatis subaequalibus patentibus $\pm 15 \times 7 \mathrm{~mm}$, filamentis styloque atropurpureis, filamentis 4-5 mm longis uno $\pm 1 \mathrm{~mm}$ breviore quam aliis, antheris $5-8 \mathrm{~mm}$ longis sagittatis lobulis ad basem per $\pm 2 \mathrm{~mm}$ divergentibus, stylo $\pm 3 \mathrm{~mm}$ longo ramis adscendentibus leviter recurvatis $\pm 3 \mathrm{~mm}$ longis.

TYPE.-Western Cape, 3320 (Montagu): Klein Roggeveld, $26.5 \mathrm{~km}$ north of $\mathrm{NI}$ on road to Sutherland from
Matjiesfontein. Farm Fortuin. (-BA), 26 August 2006, Goldblatt \& Porter 12704 (NBG, holo.; MO, PRE, iso.).

Plants 250-450 mm high. Corm 8-10 mm diam., ovoid, tunics imbricate, blackish. Stem erect, sparsely short-hairy, usually 1-3-branched, bearing a scale-like bract up to $10 \mathrm{~mm}$ long in upper third. Leaves 3, lower 2 with suberect to falcate blades, upper leaf sheathing stem but free distally, blades linear, margins raised into wings held at right angles to blade, central vein raised and bearing winged edges parallel to blade surface, ciliate on marginal and central vein wings, plane between margins and central vein. Spike flexed outward, flexuose, (3-)5- or 6-flowered; bracts unequal, outer dull grey-green in bud with submembranous margins, drying pale straw-coloured with age, $\pm 10 \mathrm{~mm}$ long. inner \pm opaque-membranous with two dark green keels, \pm 2 $\mathrm{mm}$ shorter than outer, apically forked. Flowers actinomorphic, bright, glistening pink (turning blue on drying) with a glossy, dark purple central zone, filaments, style and style branches also dark purple; perianth tube fun- 
nel-shaped, $2.0-2.5 \mathrm{~mm}$ long; tepals subequal, ovate, spreading horizontally at right angles to tube, $\pm 15 \times 7$ $\mathrm{mm}$. Stamens unequal: filaments $4-5 \mathrm{~mm}$ long, one \pm 1 $\mathrm{mm}$ shorter than other two; anthers 5-8 mm long, sagittate, thecae diverging at base for $\pm 2 \mathrm{~mm}$, pale mauvepink to purple, pollen pale pink (yellow when dry). Ovary with style slender, short, $\pm 3 \mathrm{~mm}$ long, dividing opposite lower third of filaments, style branches ascending, slightly outcurved, $\pm 3 \mathrm{~mm}$ long, extending between lower third of anthers. Capsules subglobose, 3-lobed, 6 $7 \mathrm{~mm}$ long. Seeds tetrahedral, colliculate, $\pm 2 \mathrm{~mm}$ long. Flowering time: late August to mid September, occasionally lasting until early October; flowers opening late morning and closing in late afternoon. Figure 12.

Eponymy: from the Latin, cantharis, a beetle, and -phila, loving, alluding to the pollinators, scarab beetles.

Distribution and ecology: Geissorhiza cantharophila is restricted to Klein Roggeveld and nearby (Figure 8) and is most often found on south-trending slopes or flat ground on shale and clay. In years of ample rainfall, as in 2006, plants can be so common that in flower they colour the veld with a haze of pink for many kilometres.

Diagnosis and relationships: the blackish corm tunics with overlapping layers that split regularly along the lower margin, place Geissorhiza cantharophila in subgenus Geissorhiza. The two basal leaves have broadly winged margins and a raised and winged central vein exactly like those of its presumed immediate relatives, $G$. inflexa and $G$. heterostyla, and it also has the derived pollen grains with complex aperture and operculum characteristic of its two relatives and their immediate allies. So alike are the three species that they can be distinguished only with difficulty in the herbarium. Seen alive, however, the glistening mauve-pink to purple flowers with a dark purple centre, purple filaments and a short purple style of $G$. cantharophila are unmistakable. The style, $\pm 3 \mathrm{~mm}$ long and dividing opposite the lower third of the filaments, and the almost straight style branches are unique in the subgenus and we infer that they are associated with its pollination system. The upright flowers are adapted for pollination by hopliine beetles, two or more species of which have been found on the flowers on warm sunny days. The short style results in the placement of the style branches at exactly the right level to brush against a beetle's body as it crawls across the perianth. A longer style, such as found in its relatives, would place the style branches beyond the level of a beetle visitor. Hopliine beetles captured in the flowers include Anisochelus inornatus, Anisonyx hilaris and A. ignites.

The widespread Geissorhiza heterostyla is vegetatively identical and is particularly difficult to distinguish from $G$. cantharophila when pressed and dried but alive, the blue to mauve or almost white flowers, pale yellow in the tube with the mouth sometimes edged in darker blue or mauve, and \pm white stamens and style branches make it easy to separate the two species. When the flowers of $G$. heterostyla first open, the spreading tepals are held at $\pm 30^{\circ}$ to the horizontal with the style and anthers unilateral and lying above the lowermost tepal. As the flower ages, the spike axis becomes straight and the flower is then held upright. In all but a few populations of the species, the style is relatively long and reaches the top of

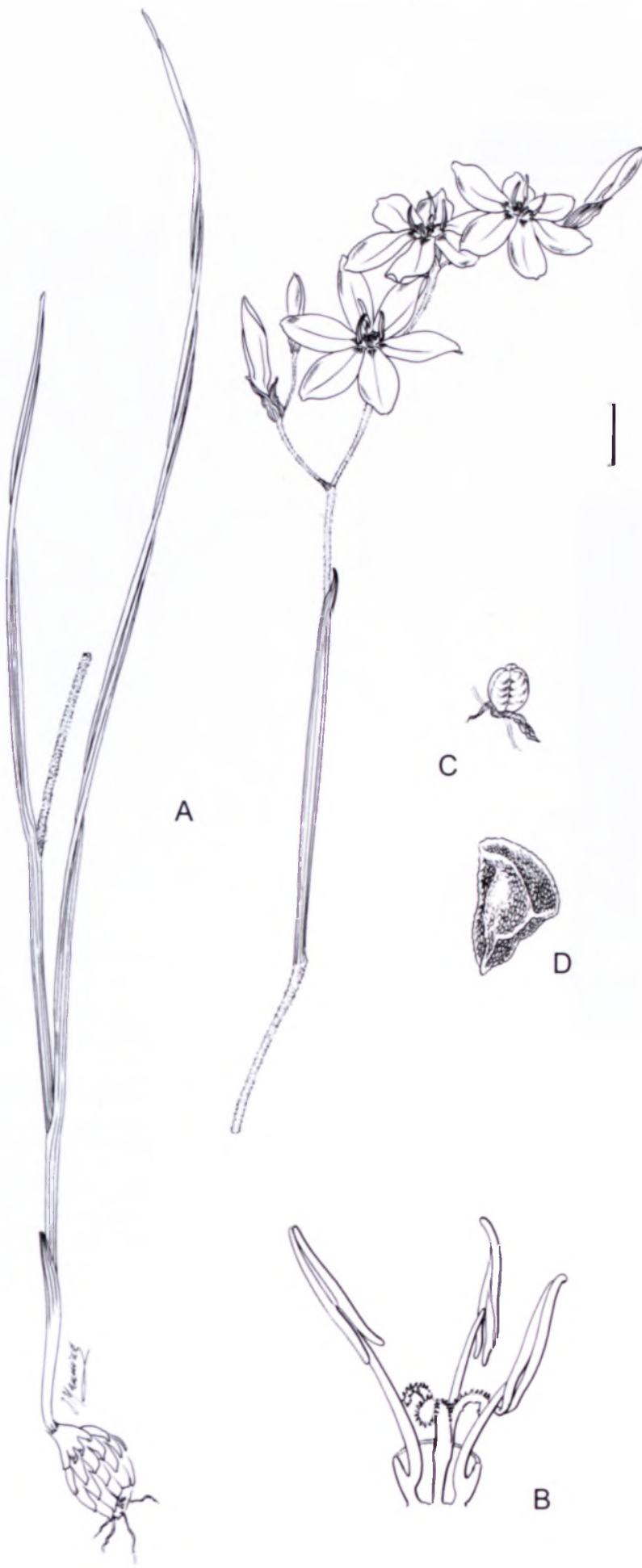

FIGLRE 12.-Geissorhiza cantharophila. Goldblatt \& Porter 12704 (NBC). A, flowering plant; B, stamens and stigma; $C$. capsule; D. seed. Scale bar: A, C, $10 \mathrm{~mm}$; B, $3 \mathrm{~mm}$; D, $1 \mathrm{~mm}$. Artist: J.C. Manning.

the anthers, and the style branches are clearly recurved as in most other species of Geissorhiza. Locally, in the southern Roggeveld, at Whitehill and elsewhere in the northern half of its range, there are populations of $G$. heterostyla that consist of plants with long, intermediate, or short styles, a feature well illustrated in the protologue (Bolus 1930), and it is these latter plants that are most easily confused with $G$. cantharophila. Short-styled plants of $G$. heterostyla are rare in any population (about one plant in 10 had a short style in two populations we 
sampled near Sutherland) and the style branches in these plants are short and recurved, thus unlike the longer, nearly straight style branches of $G$. cantharophila.

\section{Additional specimens examined}

NORTHERN CAPE.-3220 (Sutherland): Houthoek. (-CA), 10 September 1971, Hanekom 1562 (MO, NBG, PRE); Verlate Kloof, $4300 \mathrm{ft}[ \pm 1410 \mathrm{~m}],(-\mathrm{DA}), 8$ September 1926, Levins 1647 (BOL): Klein Roggeveld, Farm Meintjieskraal, (-DC), 30 August 2007, Goldhlatt \& Porter 12915 (MO, NBG. PRE); south-facing slope south of Komsberg Pass, Farm De Hoop. (-DC), 9 September 2006, Goldblat \& Porter $12807(\mathrm{MO}) ; 13.5$ miles $[ \pm 20 \mathrm{~km})$ SSE of foot of Komsherg Pass, (-DC), 15 September 1955, Acocks 18447 (BOL).

91. Geissorhiza reclinata Goldblatt \& J.C.Manning, sp. nov.

Plantae $80-120 \mathrm{~mm}$ altae, cormi tunicis imbricatis atrobrunneis, foliis usitate 3 duobus inferioribus prostratis linearibus marginibus costaque leviter incrassatis alatis ciliatis, folio supero caulem vaginanti sed distaliter libero, caule usitate 1-ad 3-ramoso, parce piloso, spica 1-ad 3-flora, bracteis inaequalibus bractea externa griseo-viridi $\pm 10 \mathrm{~mm}$ longa interna $\pm 8 \mathrm{~mm}$ longa membranacea viride bicarinata ad apicem integra, floribus zygomorphis, caeruleo-malvinis in centro viridi-flavis, perianthii tubo $\pm 2 \mathrm{~mm}$ longo infundibuliformi, tepalis anguste ovatis subaequalibus patentibus, $14-16 \times \pm 7 \mathrm{~mm}$, filamentis duobus $10-12 \mathrm{~mm}$ longis uno $8-10 \mathrm{~mm}$ longo, antheris $5-8 \mathrm{~mm}$ longis subsagittatis lobulis ad basem per $\pm 2 \mathrm{~mm}$ divergentibus, stylo reclinato ramis recurvatis $\pm 1.5 \mathrm{~mm}$ longis.

TYPE.-Western Cape, 3322 (Oudtshoorn): Swartberg. Meiringspoort, southwest-trending slopes among sandstone rocks, (-BC), 16 August 2002, Goldblatt \& Porter 12057 (NBG, holo.; MO, PRE, iso.).

Plants $80-120 \mathrm{~mm}$ high. Corm $\pm 8 \mathrm{~mm}$ diam., ovoid, tunics imbricate, dark brown, fragmenting below into tile-like sections. Stem erect, sparsely and short-hairy or sometimes \pm smooth in upper third, usually 1-3branched, bearing scale-like bract up to $10 \mathrm{~mm}$ long in upper third. Leaves mostly 3 , lower $2 \pm$ prostrate, blades linear, $80-120 \times 1.5-2.0 \mathrm{~mm}$, margins and central vein raised into narrow wings held at right angles to blade. wings sparsely ciliate, upper leaf sheathing stem but free distally. Spike flexed outward, flexuose, 1-3-flowered: bracts unequal, green flushed purple above, margins membranous, outer $\pm 10 \mathrm{~mm}$ long, inner $\pm 8 \mathrm{~mm}$ long, apex entire. Flowers zygomorphic, held at $\pm 45^{\circ}$ from vertical, blue-mauve (turning pale lilac on drying), greenish yellow in tube, upper 3 tepals dark bluepurple at base, filaments. style and style branches pale bluish; perianth tube funnel-shaped, $\pm 2 \mathrm{~mm}$ long; tepals narrowly ovate, subequal, spreading horizontally at right angles to tube, 14-16 $\times 7 \mathrm{~mm}$. Stamens unequal; filaments 10-12 mm long, one $8-9 \mathrm{~mm}$ long; anthers 5-8 $\mathrm{mm}$ long, sagittate, thecae diverging at base for \pm $2 \mathrm{~mm}$, pale mauve pink, pale yellow (or brown) when dry. Ovary with style reclinate, lying beneath filaments, dividing opposite anther tips, style branches recurved. $\pm 1.5 \mathrm{~mm}$ long, extending above anthers. Capsules and seeds unknown. Flowering time: mid August to mid September, possibly later at higher elevations.

Eponymy: from the Latin, reclinatus, bent downward. describing the orientation of the stamens and style.
Distribution: endemic to the eastern Swartberg, Geissorhiza reclinata is known only from slopes above Meiringspoort east of Oudtshoorn (Figure 8). Plants grow on moist, peaty sand on southwest-trending slopes among sandstone rocks. Plants were in full bloom the year following a fire and we suspect that, as the surrounding shrubby vegetation regrows, $G$. reclinata will no longer flower.

Diagnosis and relationships: the dark brown, overlapping corm tunics and unequal filaments place Geissorhiza reclinata in subgenus Geissorhiza where it seems taxonomically isolated. It keys out in the current revision of the genus (Goldblatt 1985) with a small group of southwestern Cape mountain species, including G. pseudinaequalis Goldblatt and G. scopulosa Goldblatt. and like the latter it has sparsely short-hairy stems and leaves with the margins and central vein winged, the wing edges minutely ciliate (at least a $10 \times$ lens is needed to see these features). The short perianth tube $\pm 2 \mathrm{~mm}$ long is consistent with that of $G$. scopulosa but the fairly large flowers with tepals $\pm 15 \mathrm{~mm}$ long are much larger than in $G$. scopulosa, which has tepals $8-9 \mathrm{~mm}$ long.

96. Geissorhiza exilis Goldblatt \& J.C.Manning. sp. nov.

Plantae $70-140 \mathrm{~mm}$ altae, cormo $3-4 \mathrm{~mm}$ diam., tunicis imbricatis atrobrunneis, foliis usitate 3 duobus inferioribus basalibus $30-40 \times 1.5-2.5 \mathrm{~mm}$ linearibus vel falcatis marginibus costaque leviter incrassatis alatis ciliatis, folio supero caulem vaginanti sed distaliter libero, caule usitate 1-vel 2-ramoso, glabro, spica 1-ad 3-flora, bracteis inaequalibus viridibus in dimidio superiore siccis brunnescentibusque, bractea externa $7-8 \mathrm{~mm}$ longa interna 5-6 mm longa bicarinata ad apicem furcata, floribus actinomorphis, albis tepalis exterioribus dorsaliter carneis, perianthii tubo $\pm 1.5 \mathrm{~mm}$ longo infundibuliformi, tepalis ovatis subaequalibus patentibus, $\pm 8 \times$ $3-4 \mathrm{~mm}$. filamentis aequalibus $\pm 2 \mathrm{~mm}$ longis, antheris $3-4 \mathrm{~mm}$ longis, stylo erecto ramis recurvatis $\pm 1.5 \mathrm{~mm}$ longis.

TYPE. - Western Cape, 3319 (Worcester): Waaihoek Mountains, Farm Boesmansvlei, steep slopes above vineyards, southwest-facing slopes among sandstone rocks, \pm 390 m, (-CA), 22 September 2007, Goldblatt \& Manning 13014 (NBG, holo.; K, MO, PRE, iso.).

Plants 70-140 mm high. Corm 3-4 mm diam., ovoid. tunics imbricate, dark brown, fragmenting below into tilelike sections. Stem erect, smooth, usually 1- or 2-branched, bearing scale-like bract up to $10 \mathrm{~mm}$ long in upper third if second branch present. Leaves mostly 3, lower 2 erect, blades linear or falcate, $30-40 \times 1.5-2.5 \mathrm{~mm}$, margins and central vein raised into narrow wings held at right angles to blade, wings prominently ciliate, upper leaf sheathing stem but free distally. Spike flexed outward, flexuose, 1-3-flowered, branches when present 1- or 2-flowered; bracts unequal, green becoming dry and brown in upper half, outer 7-8 mm long, inner 5-6 mm long, 2-keeled and forked apically. Flowers radially symmetric, upright, white with outer tepals flushed pink on reverse; perianth tube funnel-shaped, $\pm 1.5 \mathrm{~mm}$ long: tepals subequal, ovate, spreading horizontally at right angles to tube, $\pm 8 \times 34$ mm. Stamens equal; filaments $\pm 2 \mathrm{~mm}$ long: anthers $3-4$ $\mathrm{mm}$ long. white. Ovary with style erect, dividing oppo- 
site upper third of anthers, style branches recurved, \pm 1.5 $\mathrm{mm}$ long, extending above anthers. Capsules and seeds unknown. Flowering time: September.

Eponymy: from the Latin, exilis, small or slender.

Distribution and ecology: Geissorhiza exilis is known only from the slopes of the Waaihoek Mtns west of Worcester, where it grows on fairly steep slopes in sandy ground among sandstone boulders (Figure 8). The single collection was made in the spring following a fire during the previous summer.

Diagnosis and relationships: Geissorhiza exilis is identified by the narrow, sublinear to falcate leaves with the margins and central vein raised and extended into prominently ciliate wings, combined with a glabrous stem and flowers with equal filaments. Leaf morphology places the species in section Ciliatae (Goldblatt 1985) of subgenus Geissorhiza where it appears to be most like $G$. inflexa. This species is an altogether larger plant with corms $7-12 \mathrm{~mm}$ diam., leaves mostly at least $3-4 \mathrm{~mm}$ wide, and flowers with tepals at least $8 \mathrm{~mm}$ long and more often $10-18 \mathrm{~mm}$ long. The stamens of $G$. inflexa are also larger, the filaments $4.7 \mathrm{~mm}$ long, the anthers mostly 3-6 mm long, and the style branches 4-5 mm long. Whereas $G$. inflexa favours clay or loam slopes and flats in renosterveld, $G$. exilis is a plant of sandy slopes in fynbos habitats.

We have seen no other collections of the species but we suspect that it may not be as rare as it appears, for the plants are inconspicuous even when locally common and in full bloom. Difficulty in naming small-flowered species of Geissorhiza is also likely to discourage collectors.

\section{Geissorhiza saxicola Goldblatt \& J.C.Man-} ning, sp. nov.

Plantae 35-100 mm altae, cormo ignoto, caule erecto papillato-villoso simplici vel uniramoso, foliis 3 omnibus basalibus vel folio summo cauli prope basin inserto, planis falcatis vel trahentibus sublinearibus $1.5-4.0 \mathrm{~mm}$ latis marginibus costaque alatis, alis prominenter pilosis, spica (1-vel)2- ad 6-flora (ramo, si adest, 1-vel 2-floro tantum), bracteis infra viridis in dimidio superiore siccis brunneisque, bractea externa $7-8(-10) \mathrm{mm}$ longa interna breviore, floribus albis usque pallide carneis, perianthii tubo infundibuliformi 1.5-2 mm longo, tepalis 7-8 $\times 2$ $3 \mathrm{~mm}$ patentibus, filamentis inaequalibus duobus $\pm 3 \mathrm{~mm}$ longis uno $\pm 2 \mathrm{~mm}$ longo, antheris sagittatis $3.3-4.0 \mathrm{~mm}$ longis, stylo manifeste erecto ramis $1.3-1.8 \mathrm{~mm}$ longis.

TYPE.-Western Cape, 3319 (Wuppertal): Bicdouw valley, east-facing slopes above Biedouw Jeugkamp. damp sheltered places among sandstone rocks, (-AA), 7 September 1992, Goldblatt \& Manning 9404 (NBG. holo.; $\mathrm{MO}$, iso.).

Plants 35-100 mm high. Corm unknown. Siem erect, pubescent, simple or rarely with a single short branch. Leaves 3, all basal or uppermost inserted on stem shortly above ground level, \pm plane, falcate to trailing, lower two longest and exceeding stem, sublinear to narrowly swordshaped, 1.5 $4.0 \mathrm{~mm}$ wide at widest point, margins and central veins winged with marginal wings held at right angles to blade, wing edges prominently ciliate. Spike (1) 2-5(6)-flowered, branch when present 1- or 2-flowered; bracts green below, dry and brown in distal half, outer bract $7-8(-10) \mathrm{mm}$ long, inner slightly shorter, 2-veined to 2-keeled, usually shallowly notched at tip. Flowers white to pale pink, outer tepals pink to light purple outside, unscented; perianth tube funnel-shaped, 1.5-2.0 mm long; tepals 7-8 $\times 2-3 \mathrm{~mm}$, spreading. Stamens unequal; filaments with longer two $\pm 3 \mathrm{~mm}$ long, shorter one \pm 2 $\mathrm{mm}$ long; anthers sagittate, $3.3-4.0 \mathrm{~mm}$ long. Ovary with style evidently erect, dividing opposite middle of anthers, style branches arching outward, 1.3-1.8 mm long. Flowering time: August to mid October. Figure 13.

Eponymy: from the Latin, saxosa, stony or rocky, and -icola, living in, describing the habitat.

Distribution: Geissorhiza saxicola is known from just three collections from the northern Cedarberg and Pakhuis Mountains east of Pakhuis Pass (Figure 8). Plants grow in sandy soil, in moist shady sites in the shelter of sandstone rocks, and may be locally abundant.

Diagnosis and relationships: Geissorhiza saxicola is recognized by the combination of a papillate-hairy stem, leaves with the margins and central veins winged with pilose wing edges and small, pink flowers with unequal filaments. The immediate relationships of $G$. saxicola are uncertain although it clearly falls in section Ciliatae. Pollen grains are specialized in their complex aperture, which places the species closest to $G$. exilis and $G$. inftexa, but in both these species the filaments are equal in length. Although its low stature and small flowers recall G. mimuta of the Gifberg and Pakhuis Mountains, that species has a smooth stem, equal stamens, and the thickened leaf margins and central vein lack the wings with ciliate edges of $G$. saxicola. Geissorhiza leipoldtii is more distantly allied to $G$. saxicola but although it often has unequal stamens, the flowers are much larger (tepals (13-)18-28 $\mathrm{mm}$ long; anthers 6-8 $\mathrm{mm}$ long) and the style divides at or beyond the anther tips.

\section{Additional specimens examined}

WESTERN CAPE.-3218 (Clanwilliam) [or 3219 (-CA)]: Cedarberg, Boschkloof, shady damp places near rock, (-BB), 12 October 1923. Pocock 114 (NBG) or 3219 (-CA). 3219 (Wuppertal): Cedarberg Forest Reserve, Langrug, shady moist places on shale band. $100(0) \mathrm{m}$. (-AC), 5 September 1982, Viviers 584 (NBG).

\section{RANGE EXTENSIONS, MORPHOLOGICAL NOTES ANI) TAXONOMIC CHANGES}

The numbers of the species follow the classification in Table 1

\section{Geissorhiza arenicola L.Bolus}

This blue-flowered species of subgenus Geissorhiza has until now been regarded as endemic to the northern end of the Bokkeveld Mountains and nearby Gitberg range, where, as its name suggests, it occurs in sandy, well-drained soils. Allied to the widespread $G$. aspera, $G$. arenicola is recognized by the puberulous stem, two basal leaves with thickened margins and raised and thickened central vein, minutely ciliate on the edges and slightly sticky on the raised surfaces, unequal fila- 
ments and deep blue perianth with tepals mostly $12-15$ $\mathrm{mm}$ long. We have now collected the species in the Olifants River Mountains west of Trawal (Goldblatt \& Porter $11888 \mathrm{~A}$ MO, NBG, PRE). The record establishes its range as a montane species of the northern portion of the Northwestern Centre (sensu Goldblatt \& Manning 2000) of the Cape floristic region. A collection from Matjiesfontein Farm on the Bokkeveld Escarpment south of Nieuwoudtville (Goldblatı \& Nänni 1/154 NBG) consists of uniformly white-flowered plants, and a white-flowered population is also known from Lokenburg, to the south. Elsewhere $G$. arenicola has blue flowers.

\section{Geissorhiza bracteata Klatt}

The recorded range for this species is the southern Cape, extending from near Swellendam eastward to Gra- hamstown (Goldblatt 1985). New records from Burgers Pass west of Montagu extend the range some $150 \mathrm{~km}$ to the west (27 August 2006, Goldblatt \& Porter 12714 MO, NBG, PRE). A second collection from the Voetpadsberg near Touws River (3 October 1999. Goldblatt \& Nänni $11198 \mathrm{MO}$ ) in fruit is probably also this species and if correctly identified extends the range inland where it has not before been found. The Burgers Pass collection has the derived pollen type, typical of Geissorhiza bracteata but has prostrate leaves, unlike most other collections of the species, and the perianth tube is $\pm 2.5 \mathrm{~mm}$ long. Elsewhere in $G$. bracteata, the perianth tube is $3-5 \mathrm{~mm}$ long.

\section{Geissorhiza divaricata Goldblatt}

A small-flowered species, Geissorhiza divaricata (subgenus Geissorhiza) was known from the northern

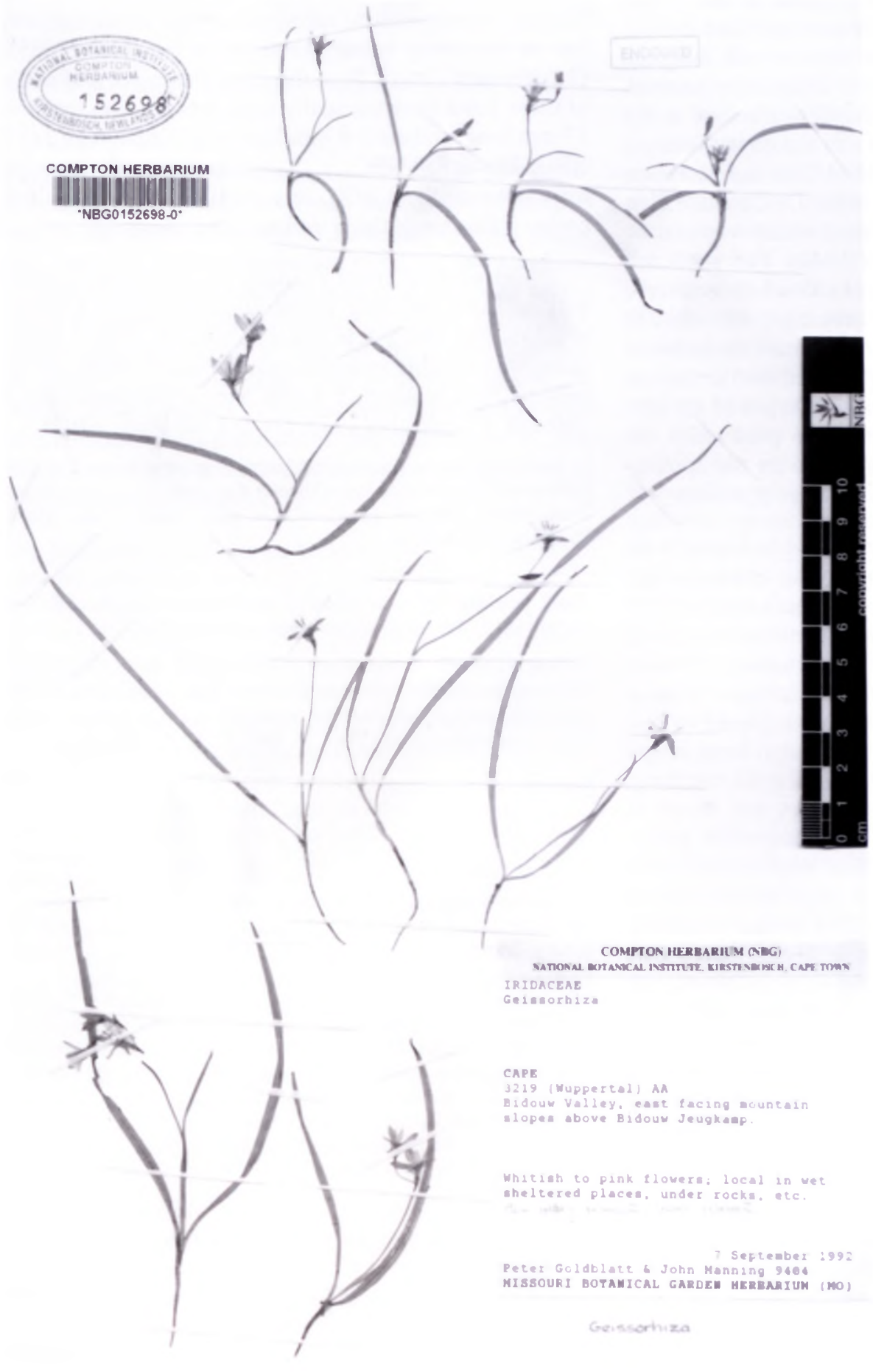

FIGLRE 13.-Geissorhiza saricola. Goldhlatt \& Manning 9404 (NBG) 
Bokkeveld Mountains and the Gifberg when described (Goldblatt 1985). The slender habit, divaricate branching with the branch about as long as the main axis, tepals \pm $10 \mathrm{~mm}$ long and the two basal leaves with raised and narrowly winged, ciliate margins and primary and secondary veins, readily distinguish the species as belonging in subgen. Geissorhiza. A collection made in September 2006, $40 \mathrm{~km}$ south of Nieuwoudtville near Moedverloor at the southern end of the Bokkeveld Mountains, is a modest range extension (Goldblatt \& Porter 12432 MO, NBG). The population there consists largely of blue-flowered plants, but one pure white-flowered plant was included in the collection. Until now records of $G$. divaricata have been of plants with white flowers faintly flushed with purple and red-purple on the reverse of the tepals.

\section{Geissorhiza erosa (Salisb.) R.C.Foster}

Based on plants cultivated in England in the 1790s, this species (as Ixia erosa) was distinguished by the leaves with ciliate 'pleats' (what we now call marginal wings) and the tips of the tepals irregularly toothed. Nothing was mentioned about the flower colour in the protologue. The reason the name was linked to the large, red- or purple-flowered plants called G. erosa by Foster was his discovery of a specimen in the De Candolle Herbarium at Geneva bearing this name, which was sent by Salisbury to De Candolle (Foster 1941). This specimen is probably not a type in the current sense, but does serve to authenticate the species. Foster regarded Ixia erosa as the earliest valid name for the illegitimate Geissorhiza hirta (Thunb.) Ker Gawl. (the name used for the species by Baker, 1896, in Flora capensis). No types of the species described by Salisbury in his 1796 publication are known and so the matter has rested. To fix the application of the name we have designated a neotype here.

The large-flowered Geissorhiza erosa is vegetatively indistinguishable from $G$. inflexa, but the spikes usually have fewer flowers, usually $2-4$, a perianth tube $1.5-2.0$ $\mathrm{mm}$ long, tepals $18-24 \times 8-10 \mathrm{~mm}$ and anthers $(6-) 7-10$ $\mathrm{mm}$ long. The outer bracts are $18-20 \mathrm{~mm}$ long, the inner $\pm 2 \mathrm{~mm}$ shorter. In contrast, typical $G$. inflexa also has a perianth tube $\pm 2 \mathrm{~mm}$ long, but tepals $10-15(-17) \times 5-7$ $\mathrm{mm}$, and anthers 4-6 mm long. The outer floral bracts are $10-15 \mathrm{~mm}$ long and the inner about $10-12 \mathrm{~mm}$ long; generally the bracts of $G$. inflexa are dry and brown at flowering, but in $G$. erosa the bracts are often green, turning light brown with age. Plants with a large, pink or occasionally white perianth that occur to the south at Villiersdorp and Bot River have, like typical $G$. erosa, tepals 18-22 mm long and anthers 8-10 mm long. Apart from perianth colour, the two sets of populations can be distinguished by bract length, tepal size and anther length (Table 3). There appear to be no consistent differences in the styles of the two species. The style generally divides opposite the level of the middle to upper third of the anthers and the style branches are $3-4 \mathrm{~mm}$ long.

Geographically, Geissorhiza inflexa in the narrow sense extends from the Piketberg and the Cape Peninsula eastward to Bredasdorp and Swellendam (Figure 14), whereas $G$. erosa occurs in the Tulbagh Valley and to the south between Villiersdorp and Bot River and near Stellenbosch, thus entirely within the range of $G$. inflexa. In view of the different pollen morphology now docu-
TABLE 3.-Comparison of taxonomically significant features of Geissorhiza erosa and $G$. inflexa. Filaments are measured from insertion on perianth tube to base of anther; for bracts measure the outer bracts in middle of spike

\begin{tabular}{lll}
\hline Character & G. inflexa & G. erosa \\
\cline { 2 - 3 } Perianth colour & $\begin{array}{l}\text { white (-cream), outer } \\
\text { tepals flushed red to } \\
\text { purple outside }\end{array}$ & $\begin{array}{l}\text { red, pink, purple, occ. } \\
\text { white }\end{array}$ \\
$\begin{array}{l}10-15(-17) \times 5-7 \\
\text { Tepal size (mm) }\end{array}$ & $\begin{array}{l}18-24 \times 8-10 \\
\text { Outer bract length } \\
\text { (mm) }\end{array}$ & $18-20$ \\
Anther length $(\mathrm{mm})$ & 46 & $(6-16)-10$ \\
Filament length $(\mathrm{mm})$ & $4-5$ & $(5-) 6-7$ \\
Flowers per spike & $(3) 4-7$ & $2-4(5)$ \\
\hline
\end{tabular}

mented for $G$. erosa populations, which we take as an indication that they constitute a genotype distinct from $G$. inflexa, and the associated larger and differently coloured flowers, we recommend recognition of $G$. erosa and outline its synonymy below. As noted by Goldblatt (1985), $G$. inflexa specimens from the Cape Peninsula and north of Cape Town have unusually large flowers with tepals \pm $17 \mathrm{~mm}$ long, anthers $\pm 6 \mathrm{~mm}$ long (e.g. Fellingham 1617 NBG; Marsh 732 NBG), and are thus apparently intermediate between those of $G$. erosa and $G$. inflexa but their pollen grains are of the $G$. inflexa type.

Geissorhiza erosa (Salisb.) R.C.Foster in Contributions from the Gray Herbarium of Harvard University 135: 52 (1941). Ixia erosa Salisb.: 36 (1796). Type: unknown (possible authentic material at G-Herb. DC.), neotype here designated: South Africa, [Western Cape.] Tulbagh, 9 September 1945, Lewis 5738 (neo., NBG).

Ixia hirla Thunb.: no. 6 (1782), nom. illeg. superfl. pro I. inflexa D.Delaroche. Geissorhiza hirla (Thunb.) Ker Gawl.: 224 (18(24). Type: South Africa, [Western Cape], without date, Thunberg s.n. (Herh. Thunberg, UPS, holo.!).

Geissorhiza rosea Eckl.: 21 (1827). Type: South Africa, [Western Cape]. near Tulbagh, cultivated in Cape Town, without date, Ecklon s.n. (S!, lecto., designated by Nordenstam 1972: 282).

Hesperantha kermesina Klatt: 15: 395 (1882). Geissorhiza erosa var. kermesina (Klatt) R.C.Foster: 53 (1941). Type: South Africa, [Western Cape], hetween Paarl and Pont, without date, Drege 8480 (B. effectively designated by Foster, 1941: 53, BM!, (i!, K!, L, MO!, S!, iso.).

\section{Specimens examined}

WESTERN (APE- - 3318 (Cape Town): near Stellenbesch, (-DD), Aug. 1878, Lightfoot s.n. (BOL3194); Steltenhosch, grounds of Veterinary Research. (-DD), Schneider suh Fellingham /6/4 (NBG); Onderpappagaiberg. lower slopes, rare on heuweltjies, (-DD), 23 August 1966. Tov tor 6882 (NBG). 3319 (Worcester): Tulbagh-Artois, (-AC), August 1885, H. Bolus s.n. (BOL); Tulbagh, lower slopes of Witzenterg. (-AC), 30 Sept. 1930, Leighton 1338 (BOL, NBG): 2 miles $[3 \mathrm{~km}] \mathrm{S}$ of Tulbagh. (-AC). 9 September 1960), Lewis 5740 (NBG); 1 mile [0.7 km] south of Tulbagh Road Station, (-AC), I September 1968. Goldhlart 304 (BOL); Wellington. (-CC), 16 August 1926, Lewis Grant 2376 (BOO). 3418 (Simonstown): Gordons Bay, (-AA), 26 September 1912, H. Bolus 9939 (BOI.). 3419 (Caledon): Van der Stel's Pass to Vyebexm, (-AA), 15 September 2007. Goldhlant \& Porter $/ 2995$ (MO, NB(i); Farm Kliptontein, west of Queen Anne, (-AA), 20 September 2001. Oliver \& Oliver 11945 (NBG): $11 \mathrm{~km} \mathrm{SW}$ of Villiersdorp. Fortuin 83 , NE of Botrivier road. (-AA), 19 Septernber 2(x)I, Helme s.n. (NBG).

\section{Geissorhiza exscapa (Thunb.) Goldblatt}

The recorded range of Geissorhiza exscapa (Goldblatt 1985), a largely Western Cape coastal species, is from immediately north of Cape Town on the Farm Blaauw- 


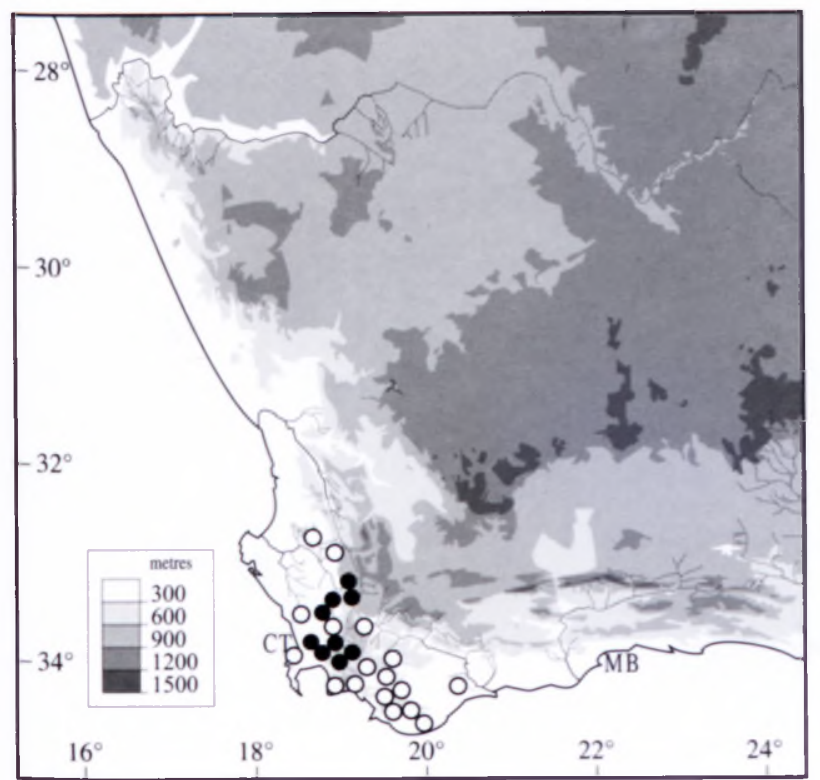

FIGURE 14.-Known distribution of Geissorhiza erosa, 0 .

berg in the south to near Leipoldtville in the north, inland on the Olifants River and Bokkeveld Mountains and in the sandveld inland of Hondeklipbaai in Northern Cape, the latter a disjunction of nearly $200 \mathrm{~km}$. New collections from the sandveld west of Koekenaap on the Farm Kommandokraal (Goldblatt \& Porter I3097 MO. NBG) and near Brand se Baai to the north (Goldhlatt \& Porter 13/25 MO, NBG) partly fills the gap in the range, leaving some $120 \mathrm{~km}$ between the Brand se Baai and Hondekliphaai populations. We suspect that $G$. exscapa occurs between these two stations but has not, as yet, been documented.

\section{Geissorhiza heterostyla L.Bolus}

The most widespread species of the genus, Geissorhiza heterostyla has been recorded from Kubiskou Mountain near Loeriesfontein in the northwest, across the Bokkeveld Escarpment and Roggeveld to the southern Cape as far east as Port Elizabeth (Goldblatt 1985). We report here a modest range extension from the Langberg, an isolated, flat-topped massif about $70 \mathrm{~km}$ west of Loeriesfontein at the southeastern edge of Namaqualand. Plants are restricted to the summit plateau of the range. at $\pm 1050 \mathrm{~m}$, where they are common among dolerite rocks in the red clay derived from decomposed dolerite (5 September 2006, Goldblatt \& Porter 12770 MO: 16 September 2006, Goldblatt \& Porter 1284l MO. NBG). The species occurs there in mountain renosterveld with other typical western Karoo geophytes including among the Iridaceae. Ixia rapunculoides. Moraea bifida and M. ripetala, and Boophone haemanthoides (Amaryllidaceac) (Goldblatt et al. 2008).

\section{Geissorhiza mimuta Goldblatt}

When described in 1985, this small-flowered species of section Geissorthiza was known only from the immediate vicinity of Pakhuis Pass and was thought to be endemic to this limited area. north of the main Cedarberg range (Goldblatt 1985). Additional collections have now been made some $50 \mathrm{~km}$ to the north on the
Gifberg summit plateau (26 September 2008, Goldblatt \& Porter $13189 \mathrm{MO}, \mathrm{NBG}$ ) and on sandstone rocks on the Matsikamma Mtns (19 October 1998, Helme 1565 NBG). By sheer chance we were able to compare living plants in full bloom from Pakhuis Pass with those from the Gifberg in September 2008 and found them to differ in no significant way. The flowers are virtually identical in size with tepals $7-8 \mathrm{~mm}$ long and although white, as described, the outer tepals of both the Gifberg and Pakhuis plants are flushed light, or sometimes dark. purple outside, a feature not before recorded. We were also able to confirm that the stamens are equal in length, which was uncertain at the time the 1985 revision of the genus was published. The habitat in the northern populations is the same as at Pakhuis Pass: wet sandstone pavement in shallow sandy ground.

\section{Geissorhiza monanthos Eckl.}

In the 1985 account of the genus, Geissorhiza lewisice R.C.Foster was included in the synonymy of $G$. monamihos (Goldblatt 1985). Field observations made since 2000 show that this decision was incorrect. Both $G$. monanthos and $G$. lewisice have unilateral stamens and style but the flowers of $G$. monamthos have a large pale, translucent centre surrounded by a dark blue to purple or red zone, and curved, bicoloured filaments pale in the lower half but dark violet distally (Figure 15A, B). The median filament is always conspicuously shorter than the others. In contrast, $G$. lewisiae has a dark blueviolet perianth, usually pale yellow-green in the throat, uniformly violet filaments with little or no curvature, the median only very slightly shorter than the others, and the anthers are semi-prostrate (Figure 15C, D). It also usually has (1)2-5 flowers per spike in contrast to $G$. monanthos, which has $1(-4)$ flowers on the main spike and only one each on one or two lateral branches. Leaves of $G$. monanthos have slightly raised margins and central veins and are always glabrous, whereas leaves of $G$. lewisiae have raised and narrowly winged margins and central veins. Populations of the species from the vicinity of Saldanha have the central vein, margins and secondary veins ciliate but populations from Citrusdal and nearby have glabrous leaves. The pollen of $G$. lewisiae is pale mauve or \pm white but $G$. monamthos has red-brown or occasionally white pollen.

We now follow Foster's (1941) decision to recognize the plants with dark, blue-violet flowers with a pale, yellow-green throat as Geissorhiza lewisiae. This species seems to us most closely related to $G$. aspera with which it is sometimes sympatric, but it is always distinguished by the larger flower size, unilateral, declinate stamens and style and more intense blue-violet pigmentation than $G$. aspera which has a \pm radially symmetric flower (although an eccentric style). with erect stamens. Both species have one slightly shorter filament. Geissorhiza lewisiae occurs in two disjunct sets of populations: a northern one around Citrusdal in the Olifants River Valley, and a western set along the Western Cape coast, from Steenberg Cove on St Helena Bay to Saldanha Bay (Figure 16). Although typically associated with granite outcrops, it also occurs on limestone pavement and calcrete in the vicinity of Saldanha Bay. Geissorhiza monamthos occurs further south, extending from Darling and Mamre (Groenekloof) inland to Malmesbury and 


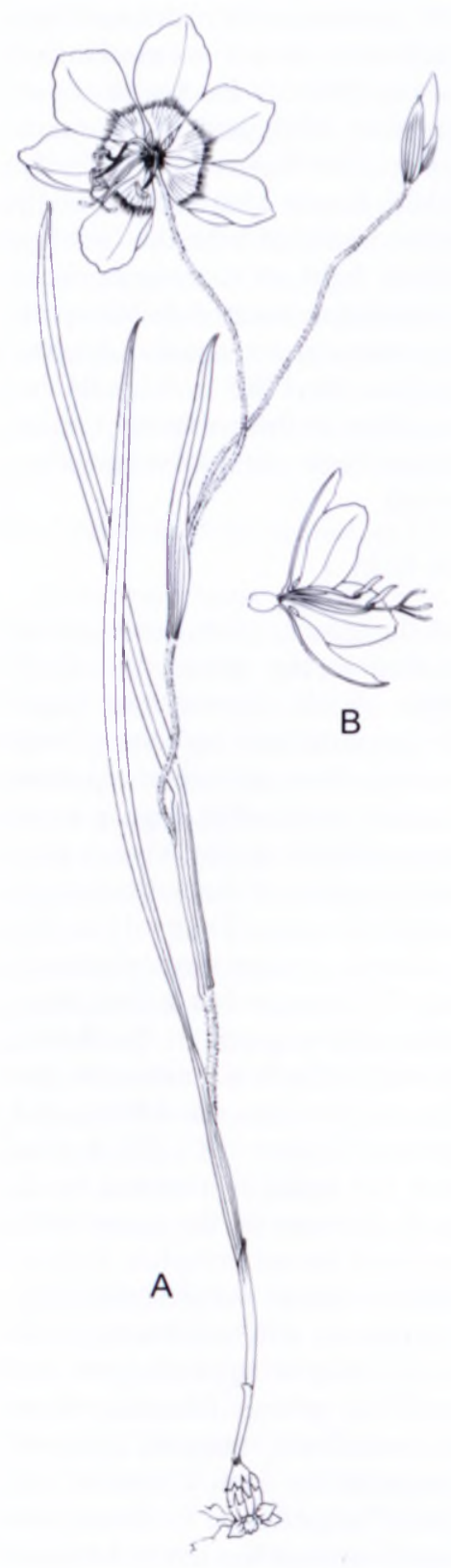

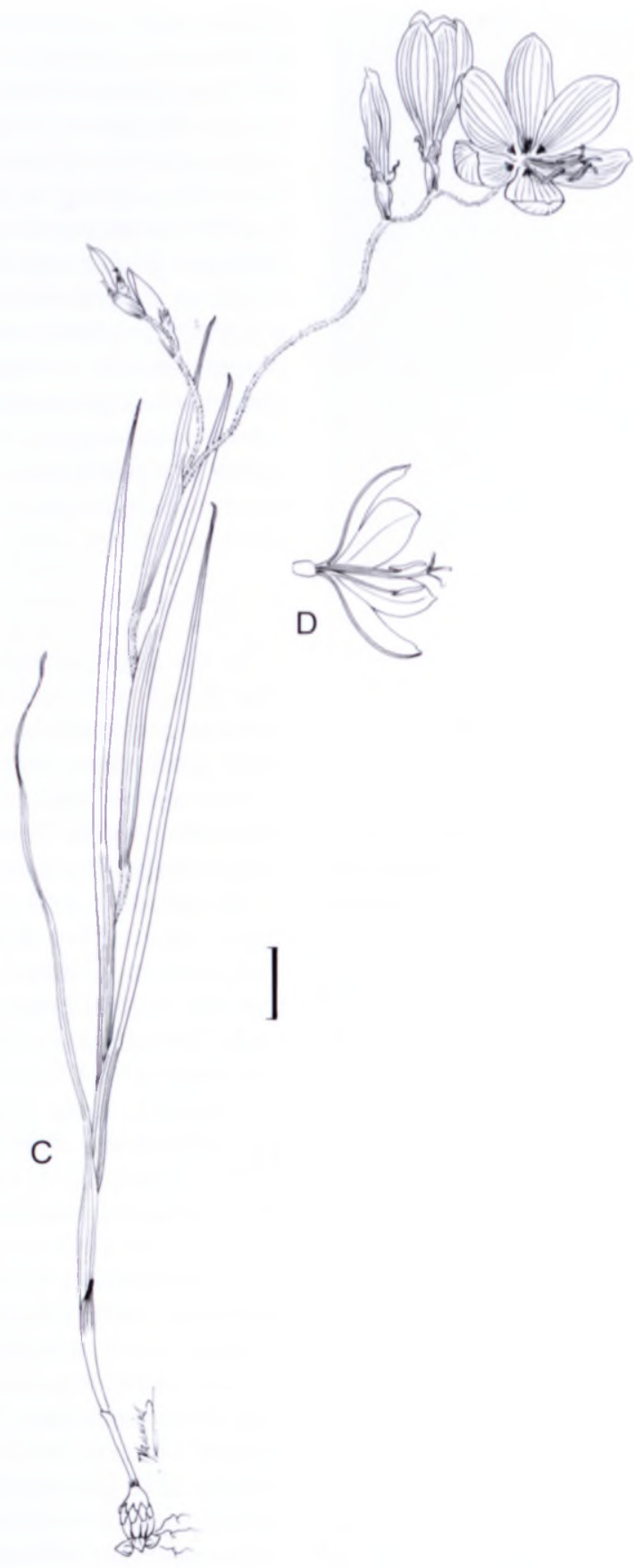

FIGURE 15-Geissorhizamonanthos. A. flowering plant: B, halfflower. Geissorhizalewisiae. C, flowering plant; D, half-flower. Scale har: $10 \mathrm{~mm}$. Artist: J.C. Manning. south to Klipheuwel and Joostenberg (Figure 16), typically occurring on gravelly, granite-derived soils.

Geissorhiza monanthos Eckl., Topographisches Verzeichniss der Pflanzensammlung von C.F Ecklon: 21 (1827); R.C.Foster: 39 (1941), as G. monantha (Thunb.) Eckl.; Goldblatt: 422 (1985, including $G$. lewisiae). Ixia monanthos Thunb.: 226 (1811), hom. illeg. non D.Delaroche (1766) (= Sparaxis sp.). Type: South Africa, Cape: exact locality unknown, Thunberg s.n. (Herb. Thunb. 975 UPS!, lecto., designated by Goldblatt 1982).

Plants 100-160(-250) $\mathrm{mm}$ high. Corm narrowly ovoid, $\pm 3.5 \mathrm{~mm}$ diam., bearing a cluster of cormlets at base, tunics imbricate, black. Stem minutely puberulous, simple or 1-, sometimes 2- or 3-branched. Leaves 3 or 4 , lower $2 \pm$ basal, \pm linear to narrowly sword-shaped, slightly shorter than stem, blade narrowed and subpetiolate below, $1.54 \mathrm{~mm}$ wide, \pm plane with central vein and margins slightly thickened, glabrous, uppermost leaf inserted in upper third of stem, much shorter than basal leaves. Spike nodding, 1 or 2(-5)-flowered. branches 1(or 2)-flowered; bracts green below, becoming dry and brown in upper half, outer $10-13 \mathrm{~mm}$ long, inner 7-10 mm long. Flowers secund, zygomorphic, violet with glossy translucent white centre broadly edged with a band of intense violet or red; perianth tube $\pm 2 \mathrm{~mm}$ long; tepals subequal, obovate, $14-18 \times 9-12 \mathrm{~mm}$, sometimes narrowed into claws below leaving tepals windowed near bases. Stamens unilateral, declinate, unequal; filaments with lower two $(6-) 8-10 \mathrm{~mm}$ long, uppermost $\pm 1.5 \mathrm{~mm}$ shorter, slightly thicker in middle, curving upward distally, white below, distal two-thirds violet; anthers 5-6 $\mathrm{mm}$ long, ascending, violet, pollen white or brown. Ovary with style dividing opposite anther tips, branches recurved, $3-4 \mathrm{~mm}$ long. Flowering time: late August to end of September. Figure 15A, B. 


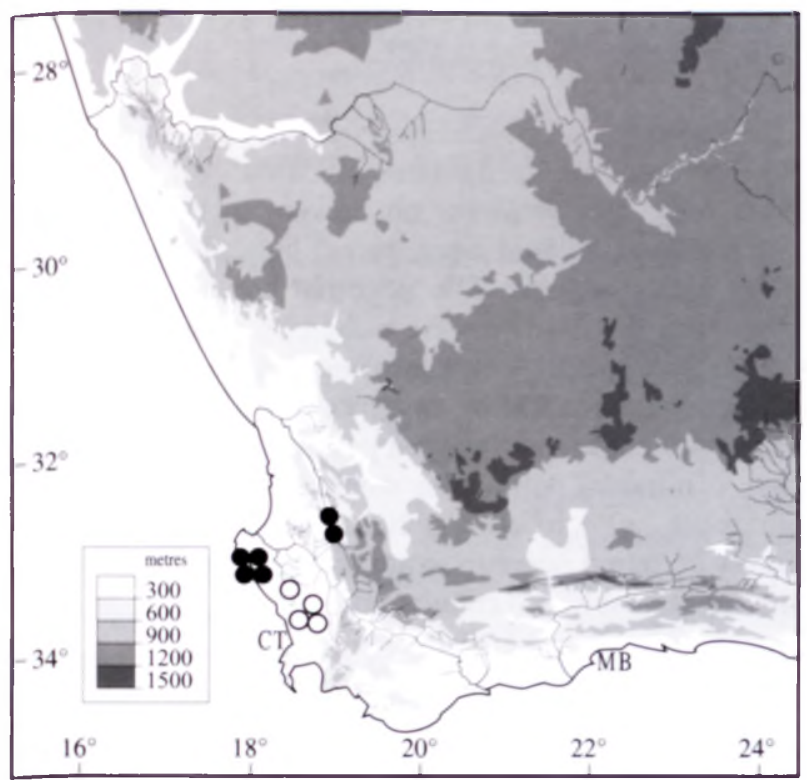

FIGURE 16.-Known distribution of Geissorhiza lewisiae. monanthos, $\mathrm{O}$.

\section{Selected specimens}

WESTERN CAPE. - 3318 (Cape Town): near Darling, (-AD), 13 September 1931, Salter 1350 (BM. BOL), Lavis s.n. (BOL 19877), 7 September 1953, Barker 8045 (NBG): hills around Darling. (AD), H Bolus 12844 (BR, MO, PRE); (iroenekloof [Mamre], (-AD). 1898, MacOwan s.n. in Herh. Norm. Ausir. Afr. 810 (B, BM. BOL, G, K, S SAM). H. Bolus 434 / (BOL. K): granite outcropping. Mud River road. (-AD), Goldhlatt 6286 (K. MO, PRE); near Oudepost, Malmesbury to Hopefield, (-BA), 28 September 1933, Salter 3873 (BM, BOL, K): Abbotsdale Station, (-BC), 24 September 1949. Martin $1 / 68$ (NBG); $10 \mathrm{~km}$ south of Malmeshury, hills west of Nassau. Farm Morgenwagt, (-DA), 17 September 2002, Helme 2560 (NB(i): 5.3 miles $( \pm 7.5 \mathrm{~km}$ ] north of Klipheuwel station. (-DA), 16 September 1982, Acocks 20644 (NBG, PRE); $\mathrm{N}$ of Klipheuwel, (-DA), 16 September 1982, Vian Zy 3186 (NBC); $0.3 \mathrm{mi}$. NE of Klipheuwel. (-DA), 6 October 1955, Lew is 4450 (SAM); Hercules Pillar, (-DD), 20 September 1944, Leighton 556 (BOL, K); Klapmuts, hard sandy ground, (-DD), 6 October 1955. Lewis 4449 (MO, PRE, SAM); Joostenberg. sandy flats, (-DD), 18 October 1961, Lewis 5902 (NB(i); Bottelaryberg. Farm Koopmanskloof, (-DD), 13 September 1988, Bevers 77 (NBG).

82. Geissorhiza lewisiae R.C.Foster in Contributions of the Gray Herbarium of Harvard University 135: 45 (1941). TYPE: South Africa, Cape: Langebaan, 7 September 1932, Lewis s.n. (K, holo., not seen; BOL20303, iso.!).

Plants 150-300 mm high. Corm narrowly ovoid, \pm 4 mm diam., with several cormlets at base. Stem puberulous, often 1-, sometimes 2-branched. Leaves usually 4 , lower two basal, blades \pm linear, mostly $2-4 \mathrm{~mm}$ wide, margins and central vein somewhat thickened and narrowly winged, glabrous or wing margins and secondary veins ciliate-hairy, uppermost cauline leaf sparsely hairy to smooth. Spike nodding in bud, flexuose, (1)2-5-flowered, branches with fewer flowers; bracts green below, dry and brown in upper half to two-thirds, outer 10-17 $\mathrm{mm}$ long, inner 8-12 mm long. Flowers secund, zygomorphic, glossy dark violet, yellow-green at base of tepals and in throat narrowly edged darker violet; perianth tube funnel-shaped, $\pm 2 \mathrm{~mm}$ long; tepals subequal, oblanceolate, outer 15-18 × 7-8 mm, inner longer and narrower, 17-20 $x \pm 5 \mathrm{~mm}$. Stamens unilateral, declinate, unequal; filaments $6-8 \mathrm{~mm}$ long, uppermost $0.5-$ $1.5 \mathrm{~mm}$ shorter, laxly reclinate, violet, sometimes pale yellow-green at base; anthers $5-6 \mathrm{~mm}$ long, reclinate, pale violet, pollen white or mauve. Ovary with style reclinate, dividing opposite anther tips, branches recurved, $3.4 \mathrm{~mm}$ long. Flowering time: late August to end of September. Figure 15C, D.

\section{Selected specimens}

WESTERN CAPE.-3217 (Vredenburg): Steenberg Cove, (-CC). 2 September 1944. Leighton 601 (BOL, K. PRE), Lewis 1038 (BOL. PRE, SAM): Jacobsbaai. calcrete, (-DD). 29 August 20(05. Helme 3536 (NBCi): Witteklip. near Vredenburg. (-DD). I September 1944. Leighton 597 (BOL), Lewis 1039 (SAM). Compton 15915 (NBG): 18 September 1980, Goldblatt 5846 (MO, NBG, US). 3218 (Clanwilliam): 5 miles $[ \pm 7 \mathrm{~km}$ ] north of Citrusdal, (-CA). 1 September 1948. Compion 2076/ (NBG): 26 August 1957, Lewis 5201 (NBG). 3317 (Saldanha): Postberg. (-BB), 8 September 1957, Lewis 5244 (NBCi). 3318 (Cape Town): Olifants Kop, east of Langebaan, (-AA), Septemher 1974. Goldblart 2705 (BR. MO. PRE, S. US, WAG).

\section{Geissorhiza tenella Goldblatt}

Geissorhiza tenella, one of three species of Geissorhiza (all subgenus Weihea section Engviphon) with leaves $\mathrm{H}$-shaped in section with broadly winged margins held \pm at right angles to the blade surface, is a lowland species of sandy, coastal and near inland habitats. Its recorded range is from Yzerfontein northwest of Darling in the west to De Hoop, near Bredasdorp in the southeast. A collection from Skulpiesbaai Reserve, Stilbaai (13 October 2000, De Villiers \& Pienaar SKB20 NBG) extends the range some $60 \mathrm{~km}$ to the east. Plants of this collection have a perianth tube $25-30 \mathrm{~mm}$ long and tepals $13 \times 2 \mathrm{~mm}$. the shortest and narrowest recorded in the species. Flower dimensions recorded until now for the species are perianth tube $(20-) 30-40(-50) \mathrm{mm}$ long and tepals 14-23 × 3.0-4.5 mm (Goldblatt 1985).

\section{FLORAL ECOLOGY}

Vogel (1954), in his touchstone account of pollination in the southern African flora, predicted (largely based on floral morphology) that Geissorhiza was primarily a bee-pollinated genus. He also inferred that at least $G$. juncea (thought by him to have flowers open at night) was moth-pollinated and that $G$. fourcadei, $G$. ovata, and $G$. namaquensis were adapted for the syndrome he called phalaenophily, in which he included butterflies and long-proboscid flies. Vogel made no direct pollinator observations in Geissorhiza but knew of Scott Elliot's (1891) report of visits to $G$. aspera (as $G$. secunda) by bees (two species of Halictidae and Apis mellifera) and a bee fly (Bombyliidae). Pollination in Geissorhiza has remained among the least known of any African genus of Iridaceae (Goldblatt \& Manning 2006) and we thus present those observations that we have accumulated over the past 15 years, noting that a more thorough study of floral ecology of Geissorhiza is needed.

A study of pollination at one site, Lions Head, Cape Town (Nänni unpubl. data, 1994 and 1995), has shown that four sympatric and \pm co-blooming, short-tubed and small-flowered species, $G$. aspera, $G$. inflexa, $G$. juncea and $G$. pusilla are pollinated predominantly by small bees (mainly Halictidae) but with occasional visits by bee flies (Bombyliidae). Hover flies (Syrphidae) and hopliine beetles were also captured while visiting $G$. aspera and G. pusilla, and in addition. Braunsapis spp. (Apidae) and honey bees were captured on $G$. aspera 
flowers (Table 4). For $G$. inflexa and $G$. juncea, halictid bees far outnumbered visits by other insects. The longtubed $G$. ovata, also present at the Lions Head site and co-blooming, was occasionally visited by halictids but its long tube and ample nectar suggests that these insects are not its legitimate pollinators as they cannot reach the nectar held within the lower part of the tube. The white and pink flower of $G$. ovala combined with the well-developed tube suggest tabanid flies are the legitimate pollinators but none were seen at the Lions Head site, nor at a second site at Sir Lowry's Pass where we observed open flowers for two consecutive mornings on warm days ideal for pollinator studies.

Experimental pollinations conducted at Lions Head using standard methods for establishing self and cross compatibility showed that Geissorhiza aspera and $G$. pusilla are self-compatible when pollinated by hand but showed reduced seed-set when not manipulated by hand (in both crosses insect visitors were excluded). In contrast, $G$. inflexa, $G$. juncea and $G$. ovata were self-incompatible. Attempts to produce interspecific hybrids by hand-crossing consistently failed. whether species from the same or different subgenera are crossed. These results complement a report of self-compatibility and autogamy in $G$. corrugata (Goldblatt 1985) and our determination here of self-compatibility in $G$. heterostyla, otherwise unknown in the genus. In one respect these results are surprising, for interspecific crosses are readily made in Gladiolus, Sparaxis and Watsonia, all members of the same subfamily, Crocoideae (Horn 1962; Goldblatt \& Manning 1998). Production of interspecific crosses is, however, possible in Geissorhiza, for there are occasional records of naturally occurring hybrids in the genus. One of these is a report of interspecific hybrids between $G$. aspera, $G$. inflexa and $G$. nulhaghensis (Lowbser 2185, 2188 BOL, NBG); another between $G$. ovala and $G$. parva (Goldblatt 1985) and a third between $G$. brehmii and $G$. radicans at Koelenhof near Stellenbosch (Bevers $80 \mathrm{NBG}$ ). The hybrids exhibit various degrees of intermediacy between the species involved.

Observations that we have accumulated since 1998 while studying the pollination of other genera of Iridaceae add modestly to this record (Table 4). Species with a short perianth tube (typically 2-4 mm long) and a radially symmetric flower, including $G$. imbricata, $G$. juncea, $G$. karooica, $G$. lowisubolusicue and $G$. ornithogaloides, are pollinated by female bees of the families Andrenidae, Colletidae and Halictidae and worker honey bees (Table 4), sometimes in combination with hopliine beetles or short-proboscid Tabanidae or butterflies. The only pollinator we have seen and captured on pink-flowered $G$. foliosa, which has a perianth tube $\pm 5 \mathrm{~mm}$ long, was the butterfly, Colias electo. Putative pollinators captured on $G$. heterostyla at different sites included halictid bees (Patellapis spp.), as well as the hopliine beetles, Anisonyx and Anisochelus, and at one site Colias elecro alone. Nectar volumes were always small, $0.5 \mu$ or less, sampled in the field using unbagged flowers. Nectar is evidently lacking in $G$. hracteata, $G$. foliosa, $G$. lonisabolusice and $G$. lulbaghensis (flowers we examined had no nectar in the middle of the afternoon). In contrast, we recorded nectar of high concentration in one population of $G$. karooica $(46.5->50 \%)$ and uniformly $>50 \%$ in a second population of $G$. karooica as well as in $G$. heterostyla and $G$. ornithogaloides.

Populations of Geissorhiza inflexa with small white flowers seem primarily bee-pollinated; we have captured only Apis mellifera on flowers of the species at one site, and halictid bees, pierid butterflies and bombylid flies at another. The large red flowers of the Tulbagh form of $G$. erosa were visited by pollen-collecting female Melitta sp. (Melittidae) and Scrapter heterodoxus. (Colletidae) bees and by two species of hopliine beetles (Table 4). These red-flowered populations thus appear to have a bimodal pollination strategy (sensu Manning \& Goldblatt 2005), offering pollen to bees and a large, brilliantly coloured perianth to attract hopliines to a suitable site for assembly and copulation.

Particularly notable is our observation for Geissorhiza inconspicua and $G$. ramosa (Table 4), which were actively pollinated by empidid thies (Empis cf. mavirii: Empidideae), small nectar-feeding Diptera $\pm 5.5 \mathrm{~mm}$ long, in combination with small halictid bees (Lasioglossum spp.). Both these species of Geissorhiza had small white flowers at our study site in Tradouw Pass (and both may also have blue flowers). We have been unable to repeat observations on additional populations of either species. We know of no other published records of pollination in the family by empidid flies but we confirmed that the flies brushed against stigmatic surfaces and carried dorsal loads of pollen, exclusively of $G$. foliosa and $G$. ramosa, on their bodies. Thus at least at the Tradouw Pass site, empidid flies were effective agents for pollen transfer, as were the halictid bees, which were far outnumbered by the empidids. Empidid flies have also been recorded by us on the shorttubed flowers of Ixia rapunculoides, Sparaxis pillansii and $S$. tricolor at sites on the Bokkeveld plateau (unpublished observations). The two Sparaxis species are believed to be adapted for hopliine pollination (Goldblatt et al. 200()b) and $I$. rapunculoides for large anthophorine bee pollination (Goldblatt e' al. 200()a).

Observations of pollination in the strikingly coloured, dark blue, red and white flowers of the Geissorhiza radians group are still unfortunately limited. We captured unidentified halictid bees and the horsefly Philoliche atricornis on $G$. eurystigma and the bee Andrena sp. (Andrenidae) and beetle Anisonve ursus (Scarabaeidae-Hopliini) on $G$. monamthos. Again, these insects carried loads of pollen of the host species and were seen to brush against stigmatic surfaces. Geissorhiza splendidissima, which has a brilliant blue perianth and brown anthers and pollen, is visited by Apis mellifera and the large Anthophora longipes.

Geissorhiza camtharophila is so far the only species of the genus shown to be primarily adapted for pollination by hopliine beetles. As mentioned above, we captured three species of beetles on flowers of the species at two different sites, Anisonyx hilaris, A. ignitus and Anisochelus inornatus (Table 4). We inter the same pollination system for $G$. tricolor because of its flower pigmentation: bright yellow with a large dark-brown central eye. The purple-flowered form of $G$. aspera from Malmesbury also requires mention here. Unlike the blue-violetand white-flowered populations, which have a yellowgreen tube edged in a darker colour, in the Malmesbury 
TABLE 4.- Insect pollinators captured on Geissorhiza species with plant voucher number. Arranged by subgenus (bee vouchers are deposited at the Snow Entomological Museum, Lawrence, Kansas; long-proboscid flies at KwaZulu-Natal Museum. Pietermaritzburg). Abbreviations: G, Goldhlatt; 1, Manning; N, Nänni; P. Porter

\begin{tabular}{|c|c|}
\hline Taxon & Captured insects (plant voucher data or reference if not an original report) \\
\hline \multicolumn{2}{|l|}{ Subgenus Weihea } \\
\hline \multicolumn{2}{|l|}{ Section Englsiphon } \\
\hline G. bonaspei Goldblatt & Prosoeca nitidula, Philoliche rostrata ( $G 1 / 640 \mathrm{MO}$ ) \\
\hline G. confusa Goldblatt & Philoliche gulosa $(G \& N$ I0572 MO): P rostrata $(G \& M / 101 / 9.11042 \mathrm{MO})$ \\
\hline G. exscapa (Thunb.) Goldblatt & Moegistorhynchus longirostris ( $G$ \& M 10346. $G \&$ \& 12628 MO): (Manning \& Goldblatt 1997) \\
\hline G. schinzii (Baker) Goldblatt & Prosoeca westermannii (not captured) $(G \&$ M / / $035 \mathrm{MO})$ \\
\hline G. tenella Goldblatt & Moegistorhynchus longirostris (Manning \& Goldblatt 1997) \\
\hline \multicolumn{2}{|l|}{ Sections Weihea and Angustifolia } \\
\hline G. bracteata Klatt & Apis mellifera $(G \& P 12714 \mathrm{MO})$ \\
\hline G. foliosa Klatt & Colias electo ( $G$ \& $M / 0783 \mathrm{MO})$ \\
\hline G. hispidula (R.C.Foster) Goldblatt & halictid bee $(G \& N / / 934 \mathrm{MO})$ \\
\hline G. inconspicua Baker & Empis cf. maviti. Lasioglossum spp. ( $G \& N / / 580 \mathrm{MO}, \mathrm{NBG})$ \\
\hline G. juncea (Link) A.Dietr. & Patellapis sp. (G //554. MO); Halictidae (4 spp.). Scrapter sp. (no voucher) \\
\hline G. karooica Goldblatt & Apis mellifera $(G \&$ \& 12929 MO. NBG) \\
\hline G. ornithogaloides Klatt & Apis mellifera, Vanessa cardui $(G \& N 11197 \mathrm{MO})$ \\
\hline G. purpurascens Goldhlatt & Hoplitis sp.. Anisomyx ursus $(G \& M / 1560 \mathrm{MO})$ \\
\hline G. pusilla (Andr.) Klatt & Halictidae (3 spp.). Bombyliidae, Syrphidae (no voucher) \\
\hline
\end{tabular}

Subgenus Geissorhiza

G. aspera Goldblatt

G. cantharophila Goldblatt \& J.C.Manning

G. eurvsrigma L.Bolus

G. heterostrla L.Bolus
Apis mellifera ( $G$ \& M 9403 NBG); Halictidae (2 spp.) Braunsapis sp.. Apis mellifera, Anisonvx ursus, Bombyliidae, Syrphidae (no voucher); Apis mellifera. Anthophora diversipes (white form. $G$ \& P $(3072 \mathrm{MO}, \mathrm{NBG}$ ): Anisonvx ursus (purple form. $G$ \& $P$ (3160 MO)

Anisochelus inornatus ( $G$ \& $P$ 12704 MO. NBG): Anisonvx hilaris, A. ignitus, $(G \& P$ 129/5 MO) halictid bee (109), Philoliche atricornis (no voucher)

Patellapis sp., Apis mellifera. Anisonix ignitus, Anisochelus inornatus (G \& P I279/ MO, NBG); halictid bees (not captured). Anisochelus inornatus ( $G$ \& $P$ 12792 MO): Colias electo (G II 43 I MO); Lasioglossum sp., Anisochelus inornatus ( $G$ \& P I280/ MO); Lasioglossum sp.. Apis mellifera $(G \& P 12962 \mathrm{MO})$

halictid bee $(G \& N / 1937 \mathrm{MO})$

Apis mellifera (G 103/0.4 MO): Halictidac (1 sp.). Bombyliidac, Pieridae (no voucher)

Scrapter heterodoxus, Melitta sp.. Perisrichia rufotihialis, Lepithrix ornatella (G 1/426 MO)

Lasioglossum (2 spp.). Patellapis sp. (G \& P 12605 MO, NBG)

Andrena sp., Anisonix ursus ( $G$ \& N $11553 \mathrm{MO}$ )

Empis cf. maviti, Lasioglossum spp.. Apis mellifera (G \& N 11578 MO. NBG)

Apis mellifera, Anthophora longipes ( $G$ \& P /3/94 MO)

Philoliche atricornis ( $G$ \& M 13019; G I1573 MO) populations the flowers are purple with the filaments and throat dark purple-black. We suspect the population has shifted from a generalist to an exclusively hopliine pollination system. Anisonyx ursus is sometimes seen on the flowers. Apart from perianth and filament pigmentation, we find no differences with typical $G$. aspera. This unusual form is threatened today by urban development as new suburbs develop around Malmesbury.

Lastly, the southwestern Cape endemic, Geissorhiza milbaghensis, which has large, zygomorphic, white flowers with a dark brown centre, is visited exclusively by the horsefly, Philoliche atricornis, also a common visitor to co-blooming Arctorheca capensis and Dimorphotheca pluvialis (Asteraceae). These two species have flower heads with dark disk florets and yellow or white rays. We speculate that $G$. zulbaghensis is a Batesian mimic of these species of Asteraceae as it offers no apparent reward to the flies; the flowers lack nectar and the pollen is held distant from the dark centre of the flower. so that only the dorsum brushes against them. Captured flies all carried dorsal loads of brown $G$. tulhaghensis pollen and ventral loads of yellow asteraceous pollen. These naked-eye pollen identifications were confirmed by microscopic examination.
The remaining information about floral ecology of Geissorhiza consists of observations on pollinator and nectar characteristics accumulated during studies of the nemestrinid fly Moegistorhnnchus longirostris (Nemestrinidae) pollination guild (Manning \& Goldblatt 1997) and of long-proboscid fly pollination systems in southern Africa (Johnson \& Steiner 1997: Goldblatt \& Manning 2000b). Species of section Engvsiphon (subgenus Weihea) with narrow. elongate perianth tubes exceeding $20 \mathrm{~mm}$, are pollinated exclusively by long-proboscid flies: $G$. bonaspei by Prosoeca niridula and Philoliche mstrata (Tabanidae): G. exscapa and $G$. tenella by Moegistorhynchus longirostris and $G$. confusa by Philoliche rostrata. We confirm pollination by long-proboscid flies in $G$. confusa and $G$. exscapa here with a record of Philoliche gulosa pollinating flowers of the former in Van der Stel's Pass near Bot River, and M. longirosIris pollinating the latter in the Olifants River Mtns near Graafwater. We have also observed $G$. schinzii of section Engysiphon being visited by Prosoeca westermannii in the Houw Hoek Mountains, but the flies avoided capture (Table 4). In addition, $G$. kamiesmontana of section Ciliata (subgenus Geisshorhiza), which has a perianth tube 
18-25 mm long, and $G$. stenosiphon with a tube $40-50$ $\mathrm{mm}$ long, are inferred to be pollinated by long-proboscid flies. The violet flower colour in G. kamiesmontana suggests it belongs to the Prosoeca peringueyi pollination guild (Manning \& Goldblatt 1996) and the white flower of $G$. stenosiphon suggests pollination by $M$. longirostris or Philoliche rostrata. Nectar of these long-proboscid fly-pollinated species is of moderate volume $(1.9-5.6 \mu \mathrm{l})$ and concentration (19.6-29.0\% mean sucrose equivalents) (references cited above and unpublished for $G$. schinzii).

Available information thus shows two primary patterns in Geissorhiza. The majority of species with radially symmetric flowers and a short perianth tube have a mixed (or generalist) pollination system using a range of female bees of at least four families and worker honey bees, sometimes together with hopliine beetles, and occasionally butterflies, short-proboscid tabanid flies, bee flies and hover flies. Small halictid bees are the most frequent visitors. Visits by Apis mellifera workers may be opportunistic for we have seen no other large-bodied bees of the family Apidae visiting Geissorhiza flowers. A second pattern is the specialization for long-proboscid fly pollination in species with narrow, elongate tubes and unilateral stamens. Pollination primarily or exclusively by hopliine beetles is known for just one species, $G$. cantharophila, but is likely in a few more, e.g. G. tricolor described above. Geissorhiza tulbaghensis appears to be a radiate daisy flower mimic. Deceptive pollination using short-proboscid Tabanidae is unique not only in the genus but in Iridaceae and we know of no other examples matching the pollination system we found in $G$. tulbaghensis. Deceptive pollination using long-proboscid flies has been inferred for two species of Hesperantha (Iridaceae) and one of Pelargonium (Geraniaceae) (Goldblatt et al. 1995, 2004a) but these species have flowers that mimic those of similar shape and colour in co-blooming Iridaceae that offer nectar. The record of empidid fly pollination in $G$. inconspicua is also unusual, and may represent a purely opportunistic event. Too little is known about the role of Empididae in pollination.

\section{ACKNOWLEDGEMENTS}

Support for this study by grants 6704-00, 7103-(01, 7316-02, 7799-05 and 8248-07 from the National Geographic Society is gratefully acknowledged. We thank Robert Brooks, Holger Dombrow, Charles Michener. Brian Stuckenberg and the late V. Whitehead for their help with the identification of insects, and Nick Helme for regularly bringing novelties to our attention, including four of the new species described here. We also extend our gratitude to Elizabeth Parker and Lendon Porter for assistance and companionship in the field; Clare Archer, South African National Herbarium Pretoria for help with several questions; Mary Stiffler, Research Librarian, Missouri Botanical Garden, for providing copies of needed literature; Roy Gereau for revising our Latin descriptions; and Sharon Bodine for help with herbarium searches. Collecting permits were provided by the nature conservation authorities of Western Cape and Northern Cape Provinces, South Africa.

\section{REFERENCES}

BAKER, J.G. 1896. Irideae. In W.T. Thiselton-Dyer, Flora capensis 6: 7-171. Reeve, London.

BOLUS, H.M.L. 1930. Plants new or noteworthy. South African Gardening 20:34-35.

BORN, J., LINDER, H.P. \& DESMET, P. 2006. The greater Cape floristic region. Journal of Biogeography 34: 147-162.

DELAROCHE, D. 1766. Descriptiones plantarum aliquot novarum. Verbeek, Leiden.

DE VOS, M.P. 1974. Die Suid-A frikaanse genus Syringodea. Journal of South African Boluny 40: 201-254.

ECKLON, C.F. 1827. Topographisches Verzeichniss der Pflanzensammlung von C.F. Ecklon. Esslingen.

FOSTER, R.C. 1941. Studies in the Iridaceac-II. A revision of Geissorhiza Ker Gawler. Contributions of the Grav Herbarium of Harvard Lniversity 135: 3-78.

GOLDBLATT, P. 1985. Systematics of the southern African genus Geissorhiza (Iridaceae-lxioideae). Annals of the Missouri Botanical Garden 72: $277+47$

GOLDBLATT, P. 1989. Geissorhiza callista (Iridaceac). Flowering Plants of Africa 50: 49-52, t. 1996.

GOLDBLATT, P., BARI. A. \& MANNING. J.C. 1991. Sulcus variability in the pollen grains of Iridaceac subfamily Ixioideac. Annals of the Missouri Botanical Garden 78: 950-961.

GOLDBLATT, P., BERNHARDT, P. \& MANNING, J.C. 1998. Pollination of petaloid geophytes by monkey beetles (Scarabaeidae: Rutelinae: Hopliini) in southern Africa. Annals of the Missour Botanical Garden 85: 215-230.

(G()LDBLATT, P., BERNHARI)T, P. \& MANNING, J.C. 2000)a. Adaptive radiation of pollination mechanisms in Ixia (Iridaceae: Crocoideae). Annals of the Missouri Botanical Garden 87: $564-577$.

GOLDBLATT, P. \& MANNING, J.C. 1995a. New species of the southem African genus Geissorhiza (Iridaceac: Ixioideae). Novon 5: $156-161$.

GOLDBLATT, P. \& MANNING, J.C. 1995b. Phylogeny of the African genera .Anomatheca and Freesia (Iridaceac-Ixioideac), and a new genus Xenoscapa. Sistematic Botanv 20: 161-178.

GOLDBLATT, P. \& MANNING, J.C. 2000)a. Cape plants. A conspectus of the Cape flora of South Africa. Strelitzia 9. National Botanical Institute, Pretoria.

GOLDBLATT, P. \& MANNING. J.C. 2000) The long-proboscid fly pollination system in southern Africa. Annals of the Missouri Boranical Gurden 87: 146-170)

GOLDBLATT, P. \& MANNING, J.C. 2006. Radiation of pollination systems in the Iridaceae of sub-Saharan Africa. Annals of Boran (London) 97: 317-344.

GOLDBLATT, P. \& MANNING, J.C. 2007. Floral biology of Babiana (Iridaceac: (rocoideae): adaptive floral radiation and pollination. Annals of the Missouri Botanical Garden 94: 709-733.

GOLDBLATT. P.. MANNING, J.C. \& BERNHARDT, P. 1995. Pollination biology of Lapeirousia subgenus Lapeirousia (Iridaceae) in southem Africa: floral divergence and adaptation for longtongued fly pollination. Annals of the Missouri Botanical Garden 82: 517-534.

(jOLDBLATT, P., MANNING, J.C., \& BERNHARDT, P. $2000 \mathrm{~b}$. Adaptive radiation of pollination mechanisms in Sparaxis (Iridaceate: Ixioideac). Adansonia sér. 3, 22: 57-70.

GOLDBLATT, P., MANNING, J.C., DAVIES,T.J., SAVOLAINEN, V. \& REZAI, S. 2004b. Cianixia, a new genus for the Socotran endemic Babiana socotrana (Iridaeac-(rocoideac). Edinburh Journal of Botany 60 ): 517-532.

GOLDBLATT, P., NÄNNI, I., BERNHARDT, P \& MANNING, JC. 2(k)4a. Floral biology of Hesperantha (Iridaceat: Crocoideac): how minor shifts in floral presentation change the pollination system. Annals of the Missouri Bolanical Garden 91: 186-206.

HOLMGREN, P.K.. HOLMGREN, N.H. \& BARNETT, L.C. 1990 Index Herbariorum, Parl l: The Herharia of the World. New York Botanical Garden, New York.

HORN, W. 1962. Breeding research on South African plants: III. Intraand interspecific compatibility in Ixia L., Sparaxis Ker., Watsonia Mill. and Zantedeschia Spreng. Journal of Sosuh African Botanv 28: $269-277$.

JOHNSON, S.I) \& STEINER, K.E. 1997. Long-tongued fly pollination and evolution of floral spur length in the Disadracomis complex. Evolution 51 : $45 \quad 53$.

KER GAWLER, J. 1804. Ensatorum ordo. Koenig \& Sims Anmals of Botany 1: 219-247 
KLATT, F.W. 1882. Ergänzungen und Berichtigungen zu Baker's Systema Iridacearum. Abhandlungen der Naturforschenden Gesellschaft zu Halle 15: 44 404.

MANNING. J.C. \& GOLDBLATT. P. 1996. The Prosoeca peringuevi (Diptera: Nemestrinidae) pollination guild in southern Africa: long-tongued flies and their tubular flowers. Annals of the Missouri Bolanical Garden 83: 67-86.

MANNING. J.C. \& GOLDBLATT, P. 1997. The Moegistorhynchus longirostris (Diptera: Nemestrinidae) pollination guild: longtubed flowers and a specialized long-proboscid fly pollination system in southern Africa. Plant Systematics and Evolution 206: $51-69$.

MANNING. J.C. \& GOLDBL.ATT, P. 2005. Radiation of pollination systems in the Cape genus Tritoniopsis (Iridaceae: Crocoideac) and the development of bimodal pollination strategies. International Journal of Plant Sciences 166: 459-474
MANNING. J.C.. GOLDBLATT, P. \& SNIJMAN, D. 2002. The color encyclopedia of Cape bulbs. Timber Press. Portland, Oregon.

NORDENSTAM, B. 1972. Types of Ecklon's 'Topographisches Verzeichniss' in the Swedish Musem of Natural History in Stockholm. Journal of South African Borany 38: 277-298.

OGDEN, E.C., RAYNOR, G.S., HAYERS, J.V. \& LEWIS, D.M. 1974. Manual of sampling airborne pollen. Hafner Press, London.

SALISBLRY, R.A. 1796. Prodromus stirpium in horto ad Chapel Allerton vigentium. London.

SCOTT ELLIOT, G. 1891. Notes on the fertilisation of South African and Madagascan flowering plants. Annals of Borany 5: $333-$ 405.

THUNBERG, C. P. 1782. Disserrario de Ixia. Uppsala.

THUNBERG, C.P. 1811. Flora capensis 2. Uppsala.

VOGEL. S. 1954. Blütenbiologische Typen als Elemente der Sippengliederung. Bolanische Srudien 1: 1-338.

APPENDIX 1.-Keys to subgenera and species of Geissorhiza. Species numbers follow the classification in Table 1

\section{Key to subgenera}

la Plants with concentric corm tunics, old tunics completely enclosed by new ones and layers splitting verrically from base or from apex, tunics usually brown and \pm woody or \pm fibrous; stamens always equal in length . . . . . . . . . . . . . . . . . . . subgenus Weihea lb Plants with overlapping corm tunics, old tunics pushed upward and fragmenting into tile-like segments from base. usually blackish and

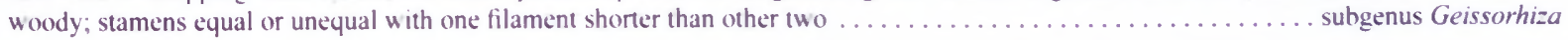

\section{Key to Geissorhiza subgenus Weihea}

la Stamens and style included in lower half of perianth tube:

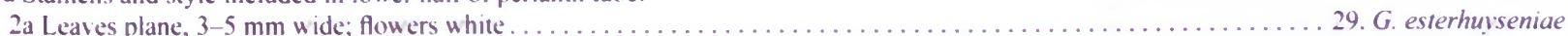

$2 \mathrm{~b}$ Leaves with margins and central veins heavily thickened. $1.5-2.0 \mathrm{~mm}$ wide: flowers pink with dark markings at hases of tepals 30 . $G$. cedarmontana

Ib Stamens and style, or at least style branches, exserted from perianth tube:

3a Foliage leaf solitary and stem with scale-like, membranous bract in upper half 38. G. unifolia

3b Foliage leaves two or more in addition to scale-like bracts in upper half of stem:

ta Leaf blades spirally twisted; style usually dividing opposite base of anthers; flowering stems each with single flower:

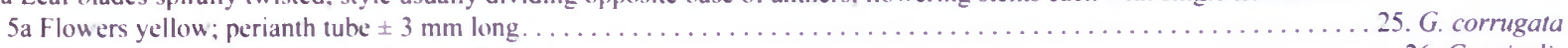

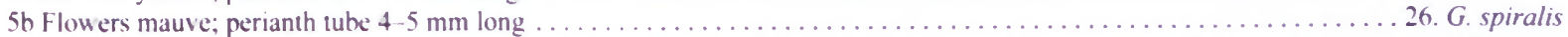

4h Leaf blades more or less straight or falcate but not spirally twisted; style dividing opposite or beyond anthers; flowering stems with one to several flowers:

6a Corm tunies entirely of fibrous layers or softly membranous, either not accumulating or becoming fibrous with age:

7a Perianth tube $2-4 \mathrm{~mm}$ long: tepals $10-13 \mathrm{~mm}$ long:

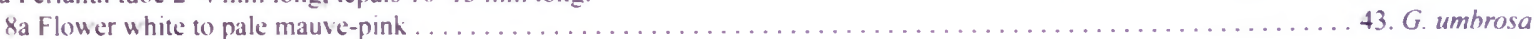

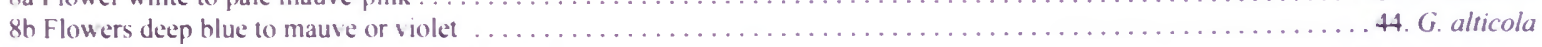

7 Perianth tube $5-18 \mathrm{~mm}$ long: tepals $12-22 \mathrm{~mm}$ long:

9a Tepals 17-22 long; perianth tube 9-18 mm long. exserted from or included in bracts:

10a Perianth tube 10-18 mm long. well exserted from tracts: corm tunics of fine, netted fibres: leaves linear. 2-grooved on each surface with margins and central vein heavily thickened; plants of open rocky slopes...............47.

I0h Perianth tube 9-13 $\mathrm{mm}$ long. not or barely exserted from bracts; corm tunics sofi-textured, soft-papen, not hecoming fibrous: leaves linear, \pm plane with margins and central veins moderately thickened: plants of waterfalls and wet. shaded

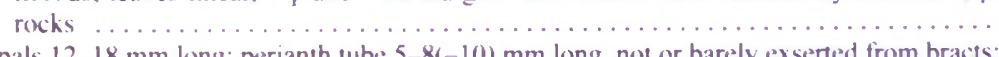

9b Tepals $12-18 \mathrm{~mm}$ long: perianth tube $5-8(-10) \mathrm{mm}$ long, not or barely exserted from bracts:

11 a Perianth pink: plants $60-120 \mathrm{~mm}$ high; lower leaves prostrate, 20-50 $\times 2.5-6.0 \mathrm{~mm}$. \pm plane with thickened margins; flow-

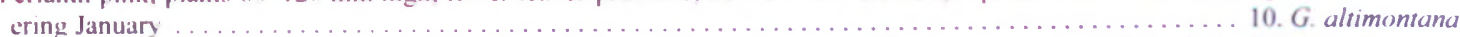

Ilb Perianth mauve to violet: plants $1(0)-300 \mathrm{~mm}$ high: leaves linear. 1-3 $\mathrm{mm}$ wide. 2-grooved on each surface with margins and central vein heavily thickened; flowering mostly late November and December:

12 a Corm tunics finely fibrous: leaves $2-3 \mathrm{~mm}$ wide; flowers without pale throat: perianth tuhe $5-\$(-10)$ mm long ... 45. G. hesperanthoides

12 b Corm tunics membranous: leaves $1.0-1.5 \mathrm{~mm}$ wide; flowers with pale throat: perianth tute $4-6 \mathrm{~mm}$ long ... 46 . G. cataractarzm 6h Corm tunics firm-papery to wordy in texture, often drawn into bristles above:

13 a l.eaves not plane, either strongly ridged, or margins and central vein heavily thickened, or blade terete with 4 nartow longitudinal grooves:

I ta Flowers moderate in size to large (tepals $(14-1) 7-40 \mathrm{~mm}$ long), mostly whitish or cream-coloured to pink, usually darker pink on reverse; stamens unilateral and declinate; bracts acute (section Engrsiphon):

15 a Leaves not sticky, tercte with hairline longitudinal grooves; perianth tube $12-20 \mathrm{~mm}$ long: tepals $20-30 \mathrm{~mm}$ long: plants of

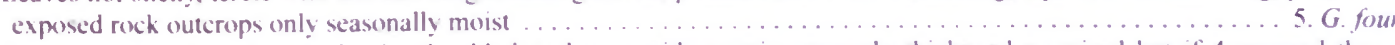

15b Leaves sticky, sometimes only sheaths, blades always with margins strongly thickened or raised but if 4 -grooved then growes clearly visible:

I 6a Leaf blades with margins raised and winged hut central vein hardly thickened, thus appearing $\mathrm{H}$-shaped in cross section. marginal wings often curving inward and blade thus appearing terete:

17a Tepals linear or narrowly lanceolate, $3.04 .5 \mathrm{~mm}$ wide. usually uniformly white

$17 \mathrm{~b}$ Tepals oblong to ohovate. 4.5-7.0 mm wide. usually whitish flushed with pink or uniformly pink:

18a Perianth tube 15-30 mm long: spike borne on well-developed stem, (1)2 4151-flowered

54. G. tenella

I 8 h Perianth tube $40.80 \mathrm{~mm}$ long: spike borne on disproportionately shon stem. sometimes spike virtually at ground level.

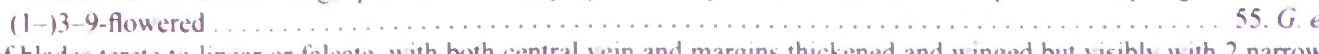

I $6 \mathrm{~b}$ Leaf blades terete to linear or falcate. with both central vein and margins thickened and winged but visibly with 2 narrou growes on each surface:

19 a Perianth tube $\pm 8 \mathrm{~mm}$ long, included in hracts and about a third as long as tepals

49. G. brevituba 
$19 \mathrm{~b}$ Perianth tube $20-50 \mathrm{~mm}$ long, reaching at least to bract apices or exceeding bracts and about as long as or longer than tepals:

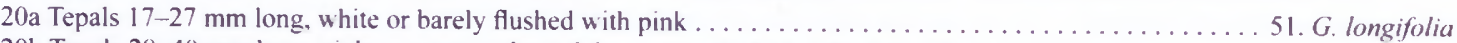

$20 \mathrm{~b}$ Tepals $28-40 \mathrm{~mm}$ long, pink or cream-coloured, becoming flushed with pink with age:





$14 \mathrm{~b}$ Flowers small to moderate in size; tepals mostly 6-25(-30) mm long, either white to yellow, or blue or deep pink (whitish

flushed pink in two species); stamens either symmetrically arranged or unilateral and declinate; bracts obtuse:

22a Leaf blade terete with four hairline longitudinal grooves:

23a Perianth tube elongate, $40-80 \mathrm{~mm}$ long.

42. G. stenosiphon

23b Perianth tube short. $2-10 \mathrm{~mm}$ long:

24a Flowers small, cream-coloured to yellow; tepals outspread when fully open, $8-14 \mathrm{~mm}$ long; perianth tube 2-3

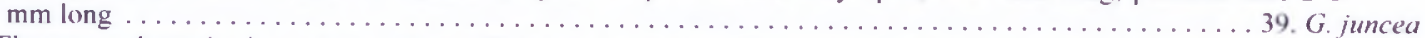

$24 \mathrm{~b}$ Flowers moderate in size, pale to golden yellow; tepals often remaining cupped when fully open, $15-25 \mathrm{~mm}$ long; perianth tube 3-9 $\mathrm{mm}$ long:

25a Flowers golden yellow; perianth tube 3-5 mm long

40. G. furves

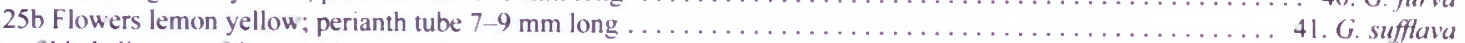

$22 \mathrm{~b}$ Leaf blade linear to falcate with two visible, relatively wide longitudinal grooves on each surface:

26a Flowers mauve, blue, purple or pink:

27a Perianth tube 7-8 mm long; spike 1-4-flowered

27b Perianth tube 3-6 mm long; spike 4-10-flowered:

28 a Plants $150-350 \mathrm{~mm}$ tall: flowers pale mave

26 b Flowers white to cream-coloured or yellow:

29a Stem minutely hairy in upper half ...

$29 \mathrm{~b}$ Stem smooth:

30a Flowers small; tepals 7-9 mm long

$30 \mathrm{~b}$ Flower moderate in size, tepals $10-22 \mathrm{~mm}$ long

3 la Bracts not normally sticky; perianth tube 9-11 mm long; flowers with dark centre . . . . . . . . . . . . 34. G. darlingensis

$31 \mathrm{~b}$ Bracts sticky and usually with sand adhering; perianth tube $3-6 \mathrm{~mm}$ long; flowers uniformly coloured inside:

32a Flowers whitish to cream-coloured, outer tepals usually flushed reddish outside; tepals $10-15 \mathrm{~mm}$ long and perianth

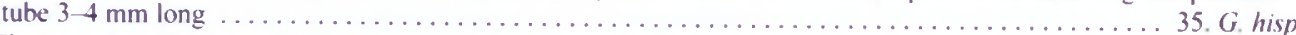

$32 \mathrm{~b}$ Flower pale yellow; tepals $16-26 \mathrm{~mm}$ long, not normally flushed red on reverse, and perianth tube $5-6(-10) \mathrm{mm}$

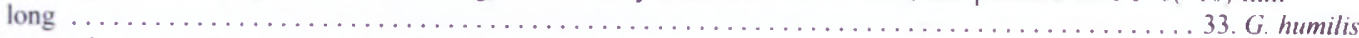

$13 \mathrm{~b}$ Leaves plane or nearly so, margins and central veins only slightly raised:

33a Flowers zygomorphic with stamens and style unilateral and declinate:

34 a Flowers purple or blue; tepals $12-18 \mathrm{~mm}$ long:

35 a Leaves prostrate, soft-textured; flowers blue-mauve; perianth tube $\pm 3 \mathrm{~mm}$ long

$35 \mathrm{~b}$ Leaves upright, firm-textured; flowers purple; perianth tube (5-)6-8 $\mathrm{mm}$ long

12. G. monicola

. . . . . . . . . . . . . 27. G. karooica

$34 \mathrm{~b}$ Flowers pink with darker markings; tepals $22-32 \mathrm{~mm}$ long:

36a Stems and leaves trailing; leaf blades soft-textured; perianth tube $10-13 \mathrm{~mm}$ long $\ldots \ldots \ldots \ldots$. . . . . . . . . outeniquensis

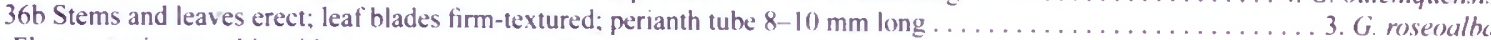

33b Flowers actinomorphic with stamens symmetrically arranged:

37a Leaves linear to narrowly sword-shaped. mostly 1-2(-4) mm wide, never hairy even on margins; spike sometimes with only I or 2 flowers:

38a Perianth tube 6-8 mm long, usually exserted from bracts; flowers white to cream-coloured. rarely pale yellow:

39a Plants 40-80 mm high; stem rarely branched, never dichotomously

$39 \mathrm{~b}$ Plants usually more than $120 \mathrm{~mm}$ high; stem usually dichotomously branched

38 b Perianth tube 2-5 mm long, included in bracts; flowers white, yellow or lilac:

4)a Flowers clear yellow; corms pointed at base or bell-shaped with flat base:

4la Flowers cup-shaped; tepals 13-25 mm long: perianth tube $\pm 4 \mathrm{~mm}$ long

$4 \mathrm{lb}$ Flowers rotate when fully open; perianth tube 2-3 $\mathrm{mm}$ long:

42a Style branches $2-3 \mathrm{~mm}$ long. filiform. ciliolate with hairs shorter than width of style branch; tepals $6-12(-18) \mathrm{mm}$ long; anthers $3-6 \mathrm{~mm}$ long

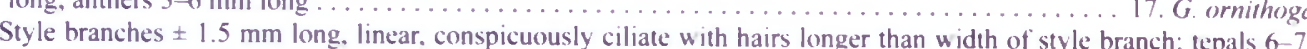

40) Flowers white or lilac; corms pointed at base:

43a Flowers tiny, tepals 3-6 mm long; perianth tube $1.0-2.5 \mathrm{~mm}$ long

43b Flowers somewhat larger; tepals 6-12 mm long; perianth tube $2-5 \mathrm{~mm}$ long

44a Flowers pale lilac or purple; perianth tube 2-3 mm long; leaves soft-textured, spreading or prostrate

4 b Flowers white; perianth tube 2-5 mm long; leaves firm, ascending to erect:

45a Perianth tube 3-5 mm long: outer tepals rarely flushed red or purple outside; leaves \pm sword-shaped. 2-9 mm wide

19. G. platsstigma

45b Perianth tube 2-2.5 mm long: outer tepals red outside; leaves up to $1 \mathrm{~mm}$ wide. linear-falcate, exceeding the ord-shaped, lanceolate or ovate, $(2-13-10 \mathrm{~mm}$ wide, smexth or hairy, sometimes only on margins; spike often

37 Leaves sword-shaped, lancer
with more than 2 flowers:

4ha Basal leaves \pm upright:

47a Perianth tube $8-10 \mathrm{~mm}$ long: flowers pale pink

$47 \mathrm{~b}$ Perianth tube $2-6 \mathrm{~mm}$ long; flowers white, pink, or blue to violet:

48a Plants branching mainly at base; flowering stems mostly 1- or 2(3)-flowered; flowers white. sometimes flushed red on reverse

13. G. bracteata

48b Plants branching above ground level, or unbranched; flowering stems usually with at least 3 flowers and as many as 7 : 49a Flowers blue: leaf sheaths and sometimes proximal parts of blades and margins minutely hairy to pubescent . . 28. $G$ pusilla $49 \mathrm{~b}$ Flowers never blue: leaves entirely smooth or minutely hairy on margins:

50) Leaves half to two-thirds as long as spike; flowers white or violet; tepals mostly $8-11 \mathrm{~mm}$ long, sometimes

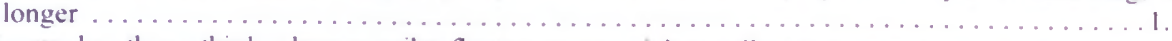

50b Leaves less than a third as long as spike: flowers mauve, pink or yellow to orange; tepals $13-17 \mathrm{~mm}$ long:

51 a Flowers deep yellow to orange, dark brown-marcon in centre. 
5 Ib Flowers pink or mauve. without dark centre:

52 Perianth tube $45 \mathrm{~mm}$ long; style branches $\pm 3 \mathrm{~mm}$ long $\ldots \ldots \ldots \ldots \ldots \ldots \ldots \ldots \ldots \ldots$ fiosa

52b Perianth tube $2-3 \mathrm{~mm}$ long; style branches $4-5 \mathrm{~mm}$ long $\ldots \ldots \ldots \ldots \ldots \ldots \ldots \ldots$ nigromontana 46b Basal leaves prostrate or inclined toward ground:

53a Perianth tube $10-30 \mathrm{~mm}$ long, as long as or longer than tepals; leaves usually broadly ovate and minutely velvety along

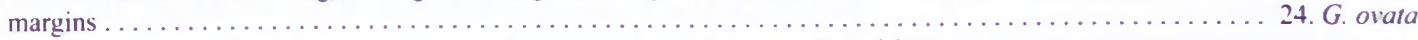

53b Perianth tube $1.5-8.0 \mathrm{~mm}$ long: leaves narrowly ovate to lanceolate, usually hairless:

54a Leaves firm-textured; cormlets never produced in aerial leaf axils:

55a Perianth tube $3-4 \mathrm{~mm}$ long; flowers creamy white to pale yellow; spike mostly 3-6-flowered .......... 23. G. paria 55b Perianth tube $2.5-3.0 \mathrm{~mm}$ long; flowers white; spike 1 - or 2-flowered . . . . . . . . . . . . . . 13. G. bracteata $54 \mathrm{~b}$ Leaves soft-textured, often flaccid; cormlets borne in aerial leaf axils:

56 a Flowers solitary on each flowering stem. lilac or blue

56 b Flowers usually more than one per flowering stem, white to pale yellow:

57a Stem either without or with only one cauline leaf: flowers fertile. capsules developing rapidly after flowering .... 21. G. ovalifolia

$57 \mathrm{~h}$ Stem bearing 2 leaves or more above ground level; flowers sterile, and cormlets produced in bract axils in place of capsules after flowering

\section{Key to Geissorhiza subgenus Geissorhiza}

la Stem minutely hairy, puberulous or pilose, sometimes only in lower part (hand lens usually needed to detect this character):

2a Perianth tube $(6-18-25 \mathrm{~mm}$ long:

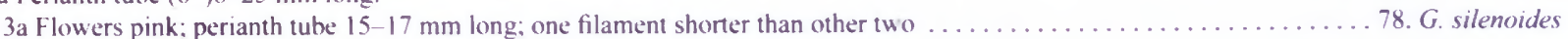

3b Flowers blue to violet; filaments equal:

4a Perianth tube (6-) $8-11 \mathrm{~mm}$ long: filaments $5-6 \mathrm{~mm}$ long

85. G. namaquensis

4 b Perianth tube $18-23 \mathrm{~mm}$ long; filaments $8-10 \mathrm{~mm}$ long $\ldots \ldots \ldots \ldots \ldots \ldots \ldots \ldots$ kamiesmontana

2b Perianth tube less than $3 \mathrm{~mm}$ long:

5 a Stamens unequal, one filament at least $0.5 \mathrm{~mm}$ shorter than other two:

6a Leaves \pm plane with margins and central vein slightly to moderately thickened, but not obviously winged; margins and central vein smooth or minutely puberulous:

7a Perianth predominantly purple. pale in throat; short filament at least $4 \mathrm{~mm}$ shorter than long filaments: tepals $18-23 \mathrm{~mm}$

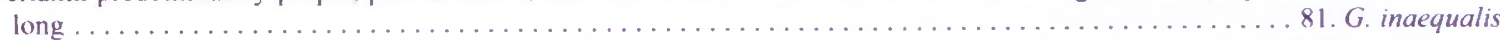

7b Perianth predominantly blue to violet or white: short filament no more than $2 \mathrm{~mm}$ shorter than long filaments: tepals 7-20 mm long:

8 a Flowers radially symmetric except for eccentric style; tepals $7-11 \mathrm{~mm}$ long: flowers violet to pale blue or predominantly white:

9a Tepals mostly $11-14 \times 4-6 \mathrm{~mm}$; spike mostly with $3-7$ flowers; anthers $3-5 \mathrm{~mm}$ long. . . . . . . . . . . . . 79. G. aspera

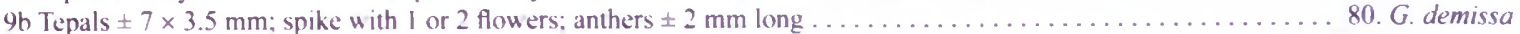

8 b Flowers zygomorphic with unilateral stamens and style; tepals $1420 \mathrm{~mm}$ long: flowers predominantly violet with pale throat or pale centre edged in dark pigment:

10a Flowers with large pale. translucent centre edged with dark violet or red; filaments curved and slightly thickened in middle;



$10 \mathrm{~b}$ Flowers violet with pale throat: filaments straight and filiform throughout; spike with $2-5$ flowers: pollen pale mauve or



6b Leaves with raised central vein (and sometimes secondary veins) bearing wings arching over leaf surface and margins with wings held \pm at right angles to blade; wing edges smooth or ciliate to long-hairy:

Il a Flowering stem with a short, membranous, scale-like bract in upper third sometimes subtending a branch:

12a Tepals $8-9 \mathrm{~mm}$ long: anthers $\pm 2.5 \mathrm{~mm}$ long

74. G. scopulosa

12b Tepals $10-22 \mathrm{~mm}$ long; anthers $4-6 \mathrm{~mm}$ long:

13a Style always short, dividing below kevel of anthers; flowers glossy pink to purple with dark centre: filaments, style and style branches dark purple ....................................... 90. Gantharophila

13b Style usually at least reaching to middle of anthers (occasional short-style plants may occur in some populations): flowers hlue to violet. mauve or white with pale centre, often edged with darker colour, style and style hranches white to pale blue or mauve:

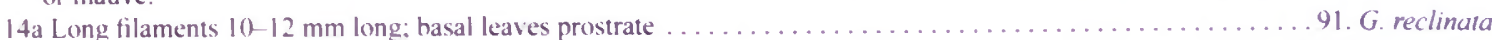

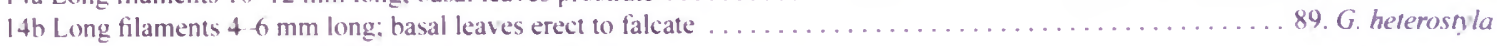

IIb Flowering stem without a scale-like bract in upper third

15a Leaves smooth or minutely hairy along margin edges; flowers blue or white . . . . . . . . . . . . . . . 92. G. arenicola

15 b Leaves conspicuously hairy along margin edges; flowers pale mauve, whitish. or pale pink:

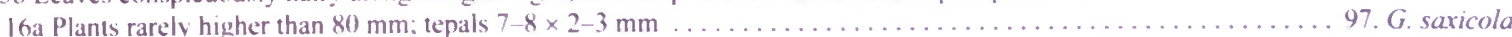

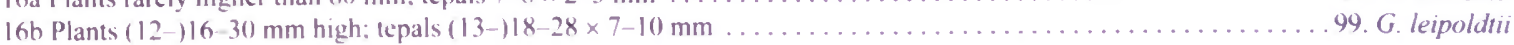

5h Stamens equal:

17 a Leaves plane with margins and central vein slightly thickened hut not winged; flowers zygomorphic with stamens and style unilateral and declinate: anthers and pollen brown:

18a Flowers white with reddish to brown-patterned centre

18 b Flowers glossy dark blue-violet, pale in throat

84. G. Wulhaghensis

17b Leaves with margins significantly thickened and/or raised into wings: flowers radially symmetric except for eccentric style: anthers and pollen not brown. usually white to yellow:

19a Leal margins and central vein thickened, rendering blades 2-grooved on each surface: margins smonth not ciliate ... . 75. G. ciliatula

$19 \mathrm{~b}$ Leaf margin edges raised at right angles to blade surface to form wings, these ciliate to hairy along edges:

20) Flowers small: tepals $6-8 \mathrm{~mm}$ long; anthers $\pm 2.5 \mathrm{~mm}$ long

98. G. eruhescens

20h Flowers larger; lepals (13-115-28 mm long: anthers $(3-168 \mathrm{~mm}$ long

99. G. leipolditi

Ib Stem smorth:

2la Stamens unequal, one at least $0.5 \mathrm{~mm}$ and usually more than $2 \mathrm{~mm}$ shorter than others; leaf margins lightly to moderately thickened

but never raised into wings extended at right angles to surface

22a Flowers small, with tepals $7-11 \mathrm{~mm}$ long:

23a Stem inclined to trailing. usually l-branched, occasionally 2-branched: flowers white

23b Stem erect. simple or usually 2-or 3-branched: flowers white or blue to violet

24a Flowers blue to violet

24 h Flowers white 
22b Flowers moderate in size to large; tepals (12-)14-30 mm long:

25a Flowers creamy yellow with or without dark centre:

26a Flower uniformly creamy yellow; tepals $18-28 \mathrm{~mm}$ long; stamens symmetrically arranged, longer filaments 7-9 mm

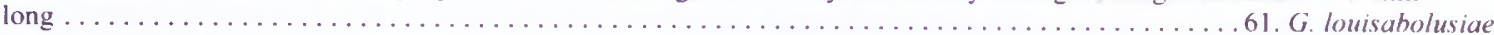

26b Flower pale yellow with blackish centre; tepals 22-30 mm long; stamens unilateral and declinate, longer filaments $15-20 \mathrm{~mm}$

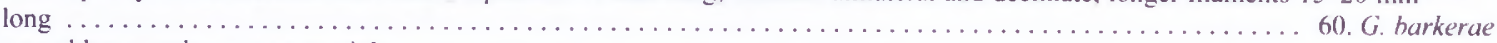

25b Flowers blue, purple, mauve, or pink:

27 a Perianth tube short, up to $3 \mathrm{~mm}$ long

27b Perianth tube 4-25 mm long:

28. Leaf blades plane

28 b Leaf blades with margins and central vein moderately to heavily thickened

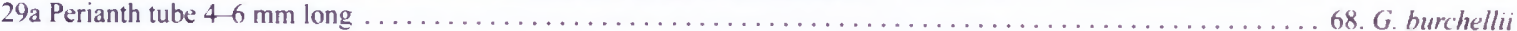

29b Perianth tube 10-25 mm long:

30a Tepals $12-15 \mathrm{~mm}$ long.

30b Tepals $22-30 \mathrm{~mm}$ long:

3 la Perianth tube $10-18 \mathrm{~mm}$ long; anthers and pollen yellow

$31 \mathrm{~b}$ Perianth tube 22-25 mm long; anthers purple and pollen pinkish

69. G. grandiftora and minutely hairy to hispid along edges:

32a Leaf blades minutely to velvety hairy on veins and margins; bracts \pm dry and rust-coloured distally at anthesis:

33a Leaf blades with margins and central vein raised and winged, minutely hairy to pubescent on edges; stem without scale-like bract in upper half:

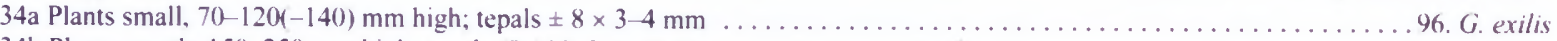

$34 \mathrm{~b}$ Plants mostly $150-250 \mathrm{~mm}$ high; tepals $(8-) 10-24 \times 6-10 \mathrm{~mm}$ :

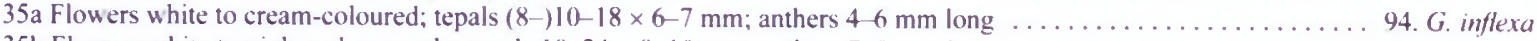

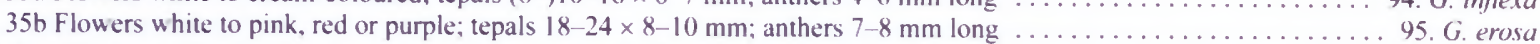

33 beaf blades \pm ribbed and velvety; stem with I or 2 scale-like bracts in upper half:

36 Flowers \pm white, outer tepals flushed reddish on reverse or uniformly blue; tepals $\pm 10 \mathrm{~mm}$ long ..........87. G. divaricala

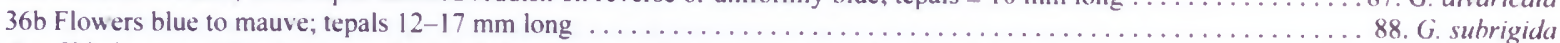

$32 \mathrm{~b}$ Leaf blades not visibly hairy or minutely hairy; bracts remaining green or dry and pale distally:

37a Leaf blades of lower two leaves linear or terete, margins and central veins moderately to heavily thickened, grooves between raised parts sometimes very narrow:

38a Foliage leaves 2, upper one sheathing lower half of stem and with short free blade; stem bearing short, membranous, scale-like

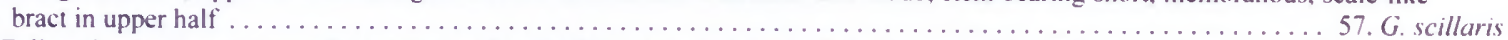

38b Foliage leaves 3, sometimes the lowermost lost by flowering time; stem without scale-like bract in upper half:

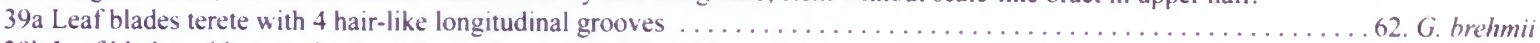

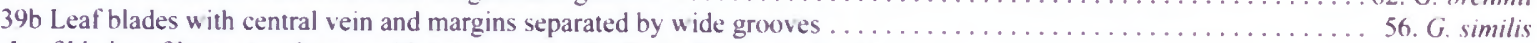

$37 \mathrm{~b}$ Leaf blades of lower two leaves with two or more ribs (including central vein):

40a Flowers white to pale yellow, sometimes with dark central mark:

4la Tepals mostly 11-25 mm long and perianth tube mostly $4-8 \mathrm{~mm}$ long; tepals often flushed reddish on reverse, often without

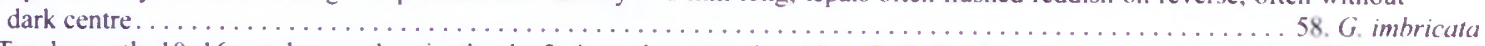

$41 \mathrm{~b}$ Tepals mostly $10-16 \mathrm{~mm}$ long and perianth tube $2-4 \mathrm{~mm}$ long: tepals seldom flushed red on reverse and with dark centre:

42a Spikes mostly 2-or 3-flowered. rarely more; perianth cream to yellow with dark brown to purplish centre ... 59. $G$. purpureolutea

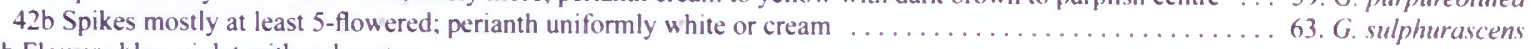
$40 \mathrm{~b}$ Flowers blue-violet with red centre:

43a Stamens and style unilateral and declinate; style branches linear-filiform; red centre of flower edged in white ....... 67. G. radians 43b Stamens and style symmetrically arranged; style branches ovate-spathulate, about $2-3 \times 2 \mathrm{~mm}$; red centre of fower not edged
in white:

44a Perianth tube 6-9 mm long; anthers erect, borne below style branches

44b Perianth tube up to $2.5 \mathrm{~mm}$ long; anthers arching inward, bome above style branches 